\begin{tabular}{ll}
\hline 2. ECN Category (mark one) \\
Supplemental & $\square$ \\
Direct Revision & $\square$ \\
Change ECN & $\square$ \\
Temporary & $\square$ \\
Standby & $\square$ \\
Supersedure & $\square$ \\
CancelNoid & $\square$
\end{tabular}

12a. Modification Work

$\square$ Yes (fill out Blk. 12b)

$\bigotimes$ No (NA Blks. 12b, 3. Originator's Name, Organization, MSIN, and Telephone No David A. Barnes, Data Development and Interpretation, R2-12, 383-3667 \begin{tabular}{l|l} 
4. USQ Required? & 5. Date \\
$\square$ Yes $\square$ No & $5 / 18 / 2000$
\end{tabular} 6. Project Title/No. Work Order No.

7. Bidg./Sys./Fac. No.

8. Approval Designator Tank Monitor and Control System

9. Document Numbers Changed by this ECN (includes 2750E, B105 ESQ sheet no. and rev.) HNE-3967, Rev 4 10. Related ECN No(s). 11. Related PO No. $N / A$ $N / A$

\begin{tabular}{|c|c|c|}
\hline $\begin{array}{l}\text { 12b. Work Package No. } \\
\mathrm{N} / \mathrm{A}\end{array}$ & $\begin{array}{l}\text { 12c. Modification Work Completed } \\
\text { N/A }\end{array}$ & $\begin{array}{l}\text { 12d. Restored to Original Condition (Temp. } \\
\text { or Standby ECNs only) } \\
\text { N/a }\end{array}$ \\
\hline & Design Authority/Cog. Engineer Signature \& & Design Authority/Cog. Engineer Signature 8 \\
\hline
\end{tabular}

13a. Description of Change

13b. Design Baseline Document? $\square$ Yes $\square$ No

The changes incorporated into the Acceptance Test Procedure will test Revision 12.0 of the Tank Monitor and Control system (TMACS) software.

USQ\#: TE-00-0362 Rev 0

14a. Justification (mark one)
Criteria Change
Design Improvement
Environmental
Facility Deactivation
As-Found
Facilitate Const.
Const. Error/Omission
Design Error/Omission

15. Distribution (include name, MSIN, and no. of copies)

see attached distribution. 


\section{ENGINEERING CHANGE NOTICE}

16. Design Verification Required

$\square$ Yes

$\bigotimes$ No
17. Cost Impact

ENGINEERING

Additional $\square$ \$

Savings $\square \$$
Page 2 of 2

CONSTRUCTION

Additional $\square$ \$

Savings $\square \$$
1. ECN (use no. from pg. 1)

654988

18. Schedule Impact (days)

Improvement

Delay

19. Change Impact Review: Indicate the related documents (other than the engineering documents identified on Side 1) that will be affected by the change described in Block 13. Enter the affected document number in Block 20.

$\begin{array}{lll}\text { SDD/DD } & \text { Seismic/Stress Analysis } \\ \text { Functional Design Criteria } & \square & \text { Stress/Design Report } \\ \text { Operating Specification } & \square & \text { Interface Control Drawing } \\ \text { Criticality Specification } & \square & \text { Calibration Procedure } \\ \text { Conceptual Design Report } & \square & \text { Installation Procedure } \\ \text { Equipment Spec. } & \square & \text { Maintenance Procedure } \\ \text { Const. Spec. } & \square & \text { Engineering Procedure } \\ \text { Procurement Spec. } & \square & \text { Operating Instruction } \\ \text { Vendor Information } & \square & \text { Operating Procedure } \\ \text { OM Manual } & \square & \text { Operational Safety Requirement } \\ \text { FSAR/SAR } & \square & \text { IEFD Drawing } \\ \text { Safety Equipment List } & \square & \text { Cell Arrangement Drawing } \\ \text { Radiation Work Permit } & \square & \text { Essential Material Specification } \\ \text { Environmental Impact Statement } & \square \\ \text { Environmental Report } & \square & \text { Fac. Proc. Samp. Schedule } \\ \text { Environmental Permit } & \square & \text { Inspection Plan }\end{array}$

Tank Calibration Manual Health Physics Procedure Spares Multiple Unit Listing Test Procedures/Specification Component Index ASME Coded Item Human Factor Consideration Computer Software Electric Circuit Schedule ICRS Procedure Process Control Manual/Plan Process Flow Chart Purchase Requisition Tickler File

20. Other Affected Documents: (NOTE: Documents listed below will not be revised by this ECN.) Signatures below indicate that the signing organization has been notified of other affected documents listed below.

\section{$\mathrm{N} / \mathrm{A}$}

21. Approvals

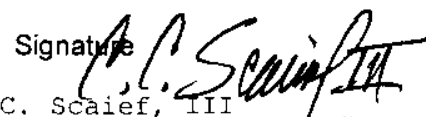

Design Authority C.C. Scaief, II Cog. Eng. D.A. Barnes Na kaulig Cog. Mgr. J. G. Field $q \mathcal{4}$ ield QA w. O. Adams this adanes 5/18/00 Safety AA Cutforth Kun Cuffork $5 / 23 / 00$ Environ. ․ C. Milier g8 sule for $5 / 19 / 200$ Other

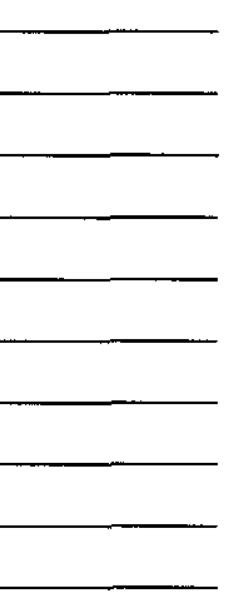

Design Agent

PE

QA

Safety

Design

Environ.

Other

\section{DEPARTMENT OF ENERGY}

Signature or a Control Number that tracks the Approval Signature

ADDITIONAL 


\title{
Tank Monitoring and Control System (TMACS) Acceptance Test Procedure
}

\author{
D. A. Barnes \\ CH2M Hill Hanford Group Inc. \\ Richland, WA 99352 \\ U.S. Department of Energy Contract DE-AC06-99RL14047
EDT/ECN: 654988: UC: $605^{-}$
Cost Center: 74B50 Charge Code: 102608EB00 \\ B\&R Code: EW3120071 Total Pages: 76
}

Key Words: Acceptance Test Procedure, ATP, TMACS, Tank Monitor and Contro 1 system (TMACS), Rev. 12.0

Abstract: This document is used to validate Revision 12.0 of the Tank Moni tor and Control system (TMACS) and verify it functions as intended by design.

TRADEMARK DISCLAIMER. Reference herein to any specific commercial product, process, or service by trade name, trademark, manufacturer, or otherwise, does not necessarily constitute or Imply its endorsement, recommendation, or favoring by the United States Government or any agency thereof or its contractors or subcontractors.

Printed in the United States of America. To obtain copies of this document, contact: Document Control Services, P.O. Box 950, Mailstop H6-08, Richland WA 99352, Phone (509) 372-2420; Fax (509) 376-4989.
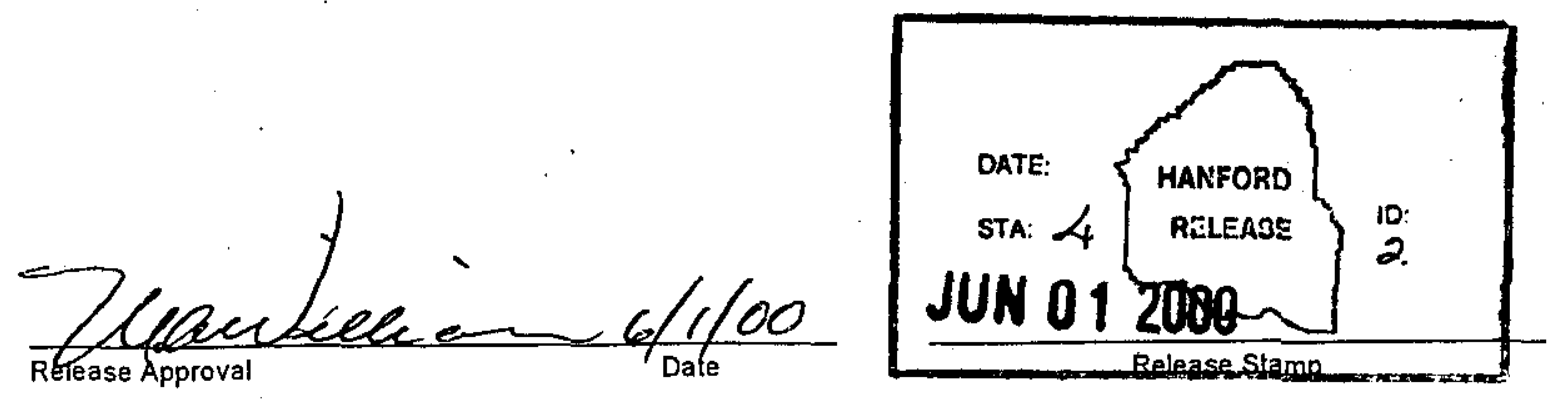

Approved For Public Release 


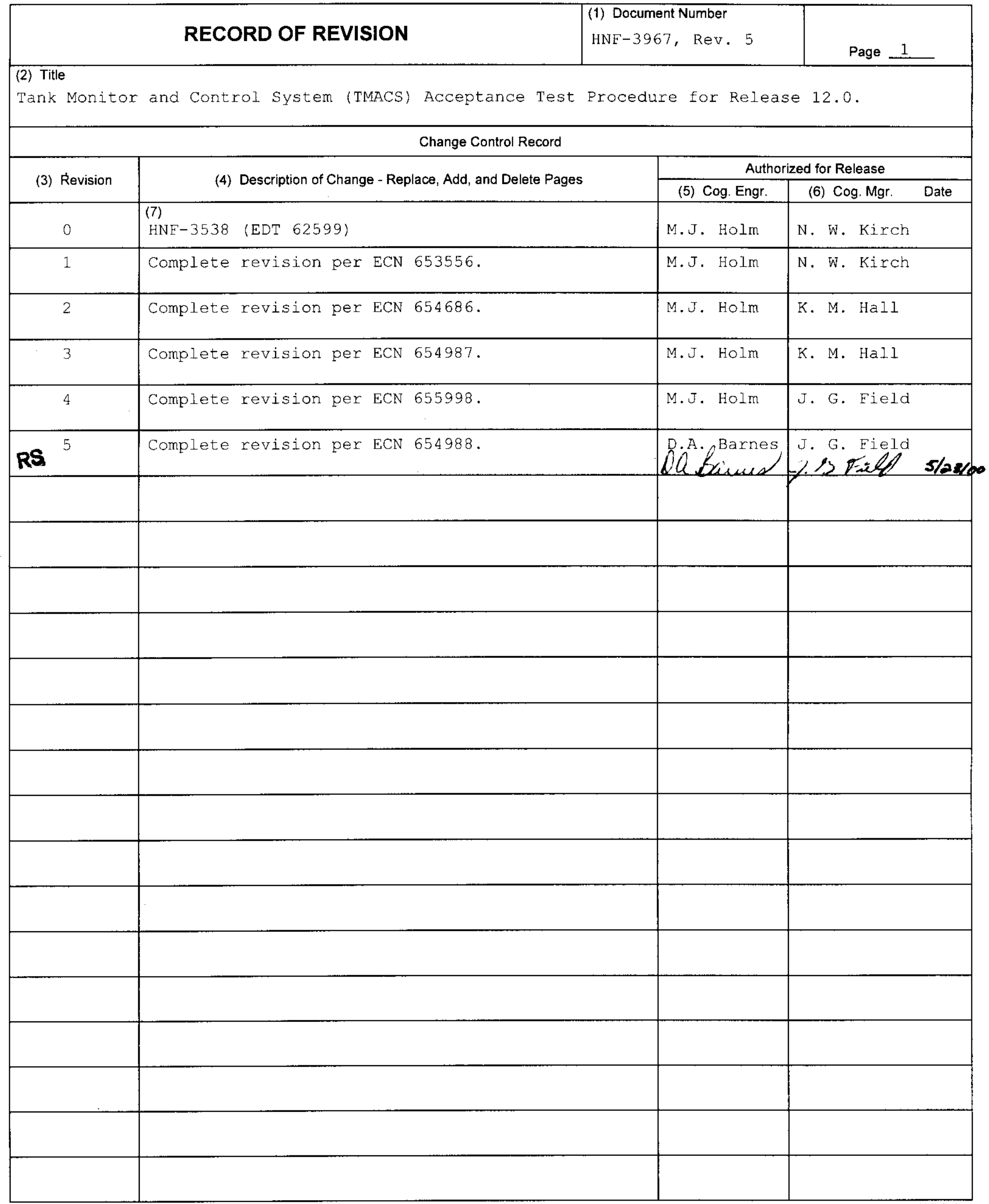


HNF-3967, Rev. 5

\title{
TANK MONITOR AND CONTROL SYSTEM (TMACS) ACCEPTANCE TEST PROCEDURE
}

\author{
Prepared By \\ Ronald R. Wandling \\ Lockheed Martin Services Inc. \\ For \\ CH2M HILL Inc \\ For \\ US Department of Energy \\ Office of River Protection \\ Richland, Washington
}




\section{TABLE OF CONTENTS}

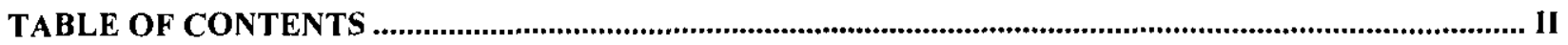

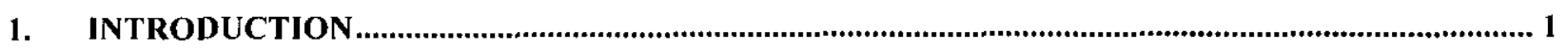

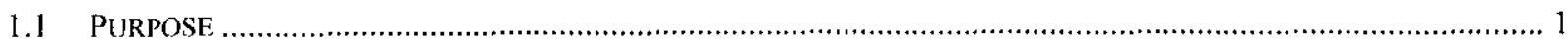

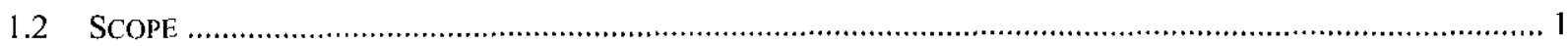

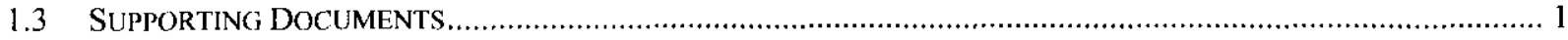

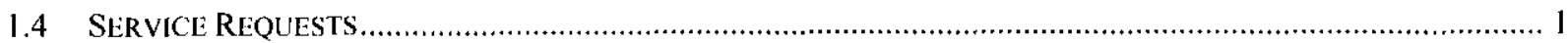

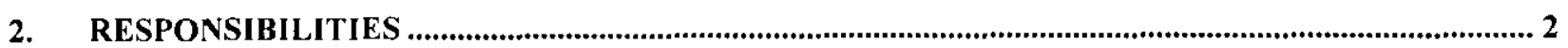

2.1 TEST DIRECTOR

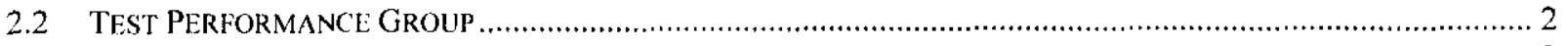

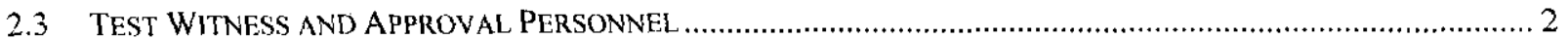

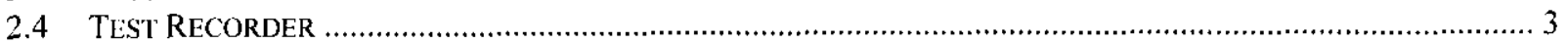

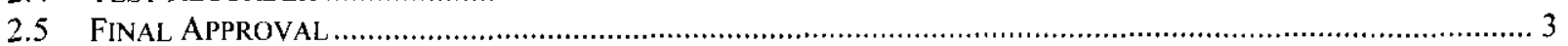

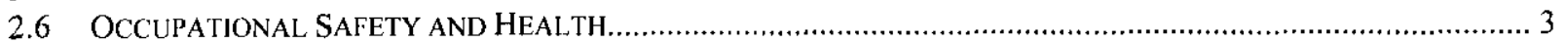

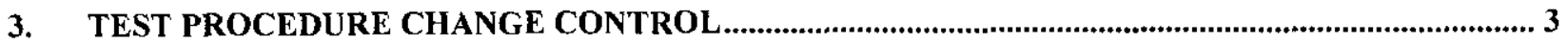

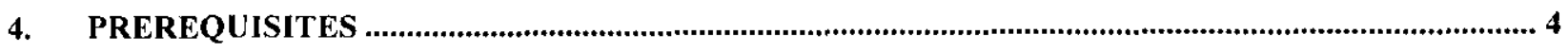

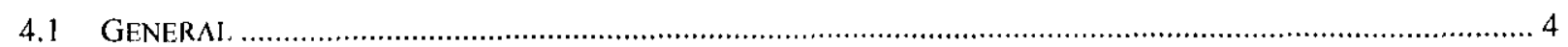

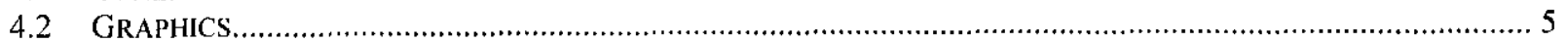

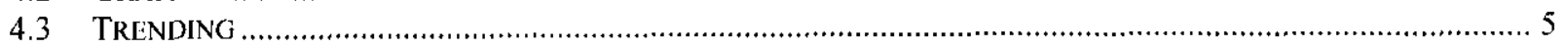

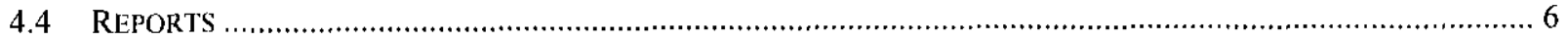

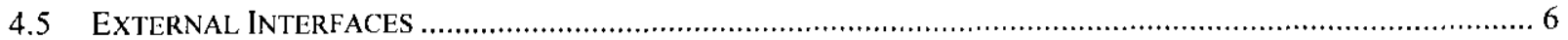

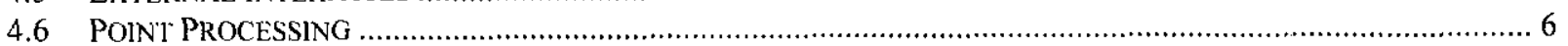

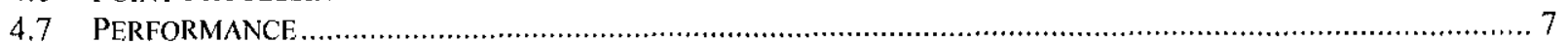

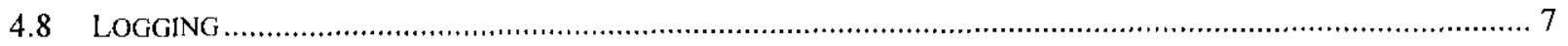

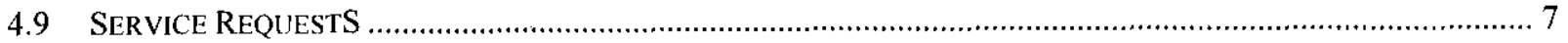

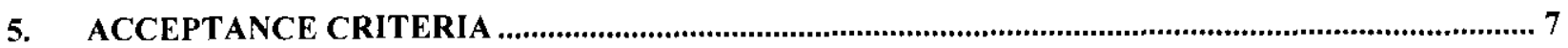

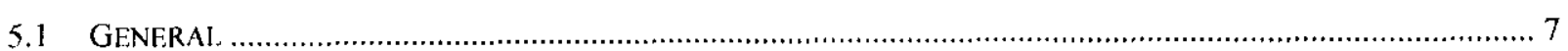

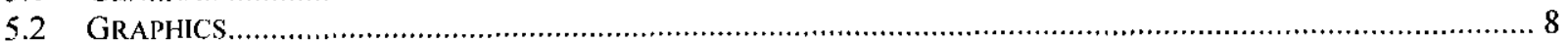

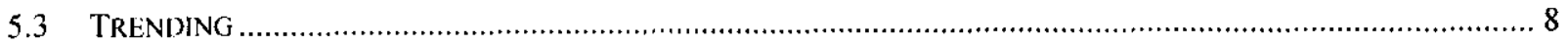

5.4 REPORTS ……

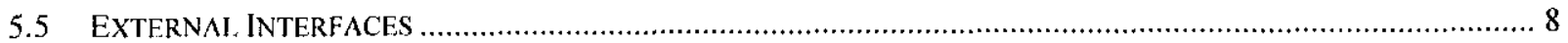

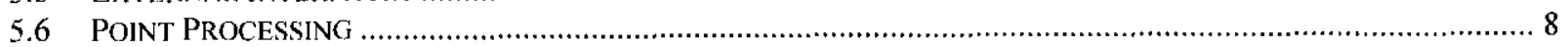

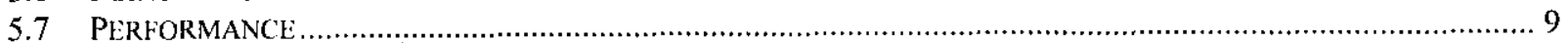

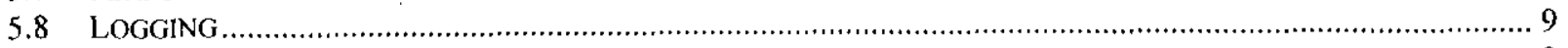

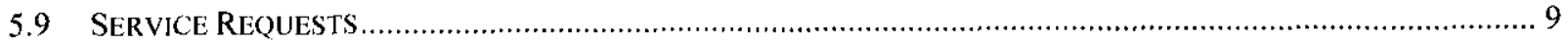

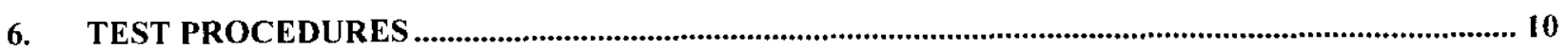

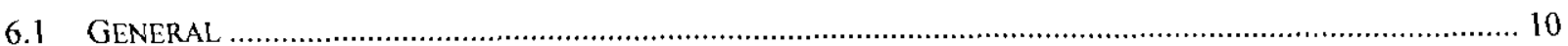

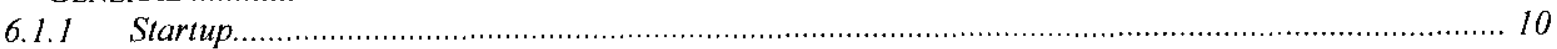

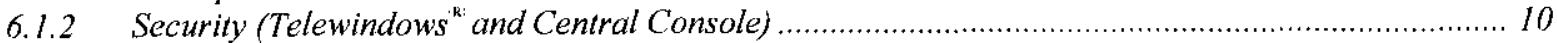

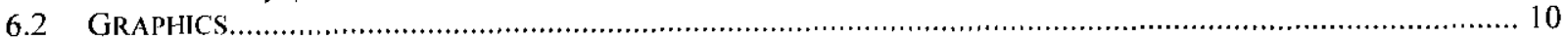

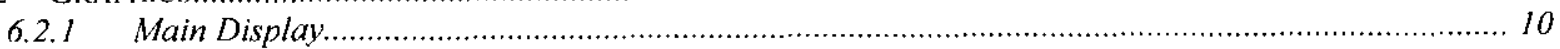

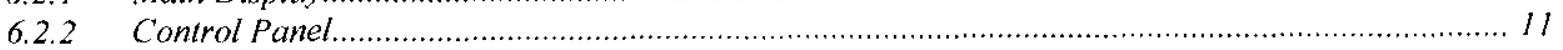

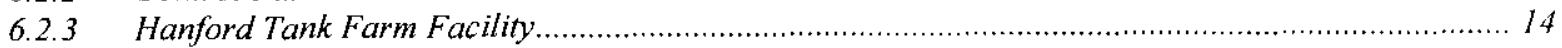

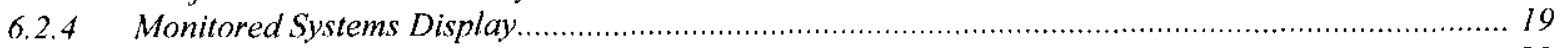

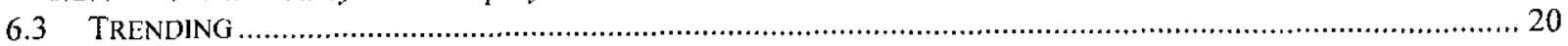

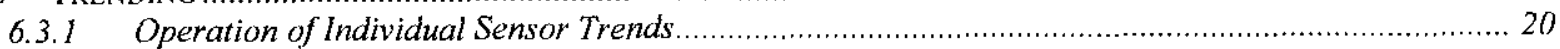

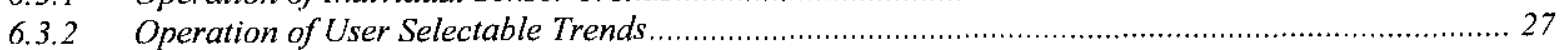




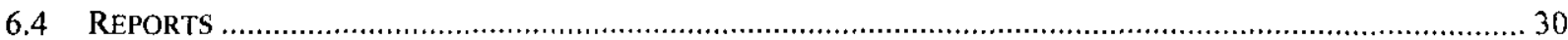

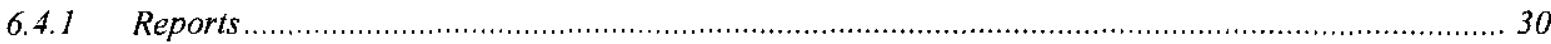

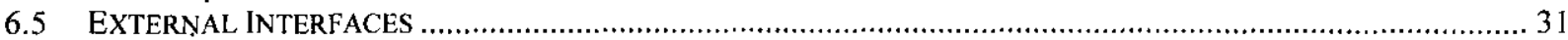

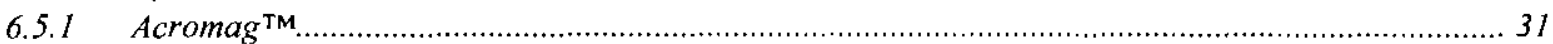

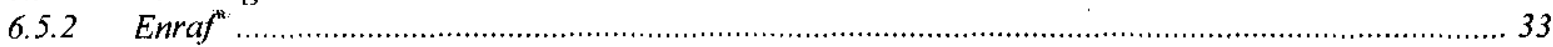

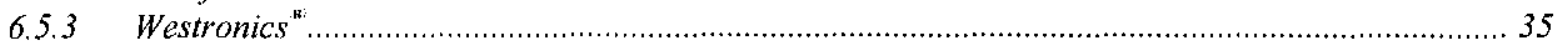

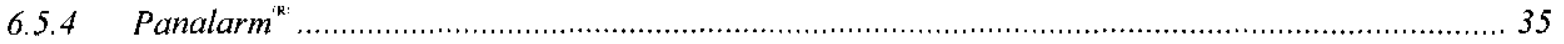

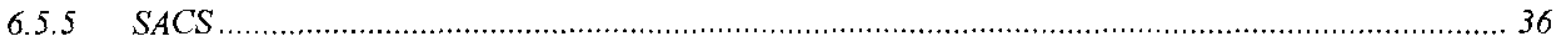

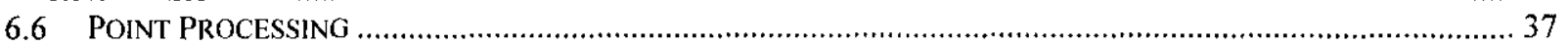

6.6.1 Continuous Sensor (Non Rate of Change) Automated Functional Test ......................................... 37

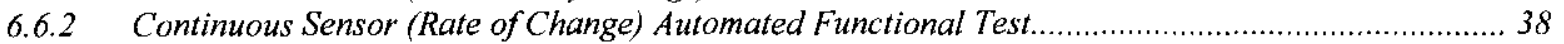

6.6.3 Discrete Sensor Automated Functional Test .................................................................... 38

6.6.4 Operation of MOST RECENT ALARM and CURRENT ALARMS..........................................39

6.6.5 Operation of Sensor Delta Band and Alarm Deadband .....................................................40

6.6.6 Operation of Enable/Disable Procedures............................................................................... 41

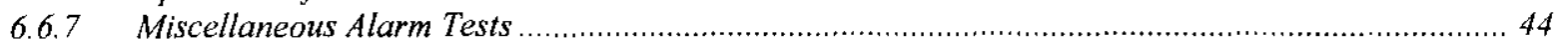

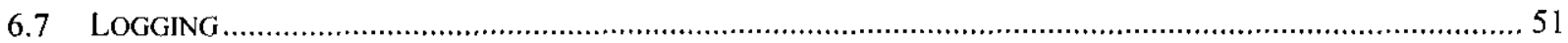

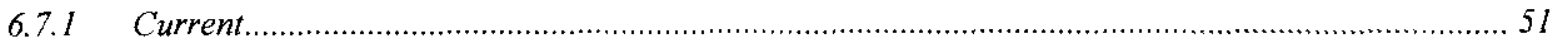

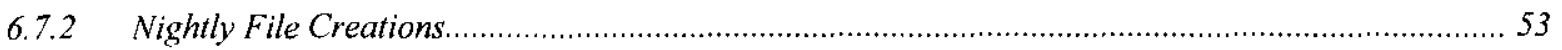

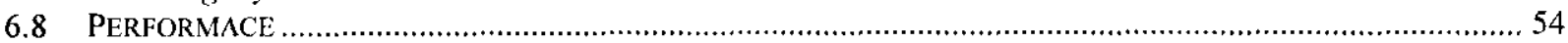

6.8.1 CPU Use VS Number of Continuous Points/Sec Performance Test ............................................. 54

6.8.2 CPU Use Vs Number of Discrete Points/Sec Performance Test................................................. 55

6.8.3 CPU Use Vs Pt-Processing Function for Continuous Points Performance Test............................ 55

6.8.4 CPU Use Vs Point-Processing Function for Discrete Points Performance Test ............................. 56

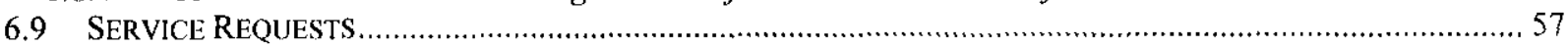

6.9.1 SR 455 - Make the Unit of Measure for Enrafs consistent ..................................................... 57

6.9.2 SR 7II - Correct The Acromag remote procedure "Write Digital" ............................................. 57

6.9.3 SR 878 - Fix Suspect I/O Report Abort Problem ............................................................ 57

6.9.4 SR 879 - Fix Reports So The Number Found Matches The Number Displayed............................. 57

6.9.5 SR 880 - Make Unacknowledge Alarms Stop Blinking when Alarm Processing is Disabled ........... 58

6.9.6 SR 884 - Fix Remote Procedure Calls So Limit Of 4096 Is Not Reached........................................ 58

6.9.7 SR 885 - Create a function to raise the ClU Enraf displacers on a routine basis ............................ 59

6.9 .8 SR $889-200$ inch Acromag Conversion Formula ............................................................60

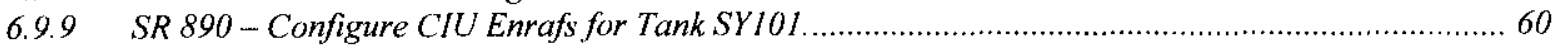

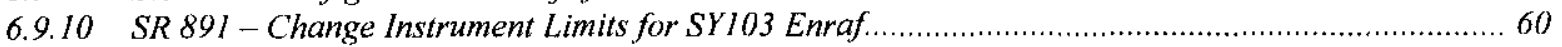

6.9 .11 SR 892 - Support the transfer of CASS Alarms to TMACS ..........................................................61

6.9.12 SR 899 - Move RAWDATA Insert Process onto TMACSPROD .................................................61

6.9.13 SR 902 - Modify TMACS to insert SACS nightly Reading Directly ...........................................62 62

6.9.14 SR 903 - Update Operating System to NT 4.0 Service Pack 5.0 ...........................................62

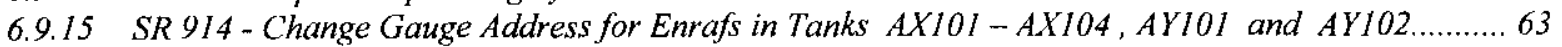

6.9.16 SR 915 - Add Enrafs To Tanks AZ102, AZ151, B101-B112, and B201-B204..............................64

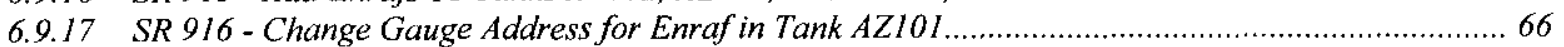

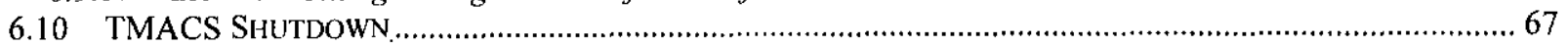

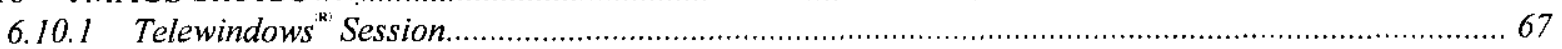

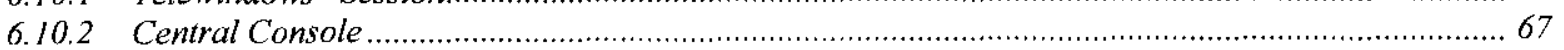

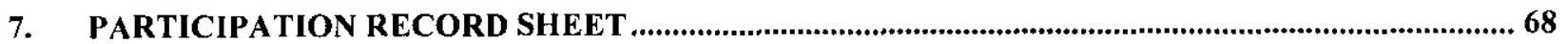

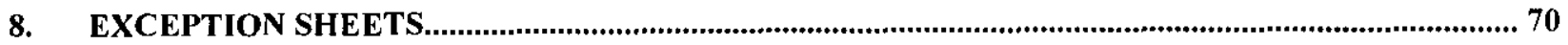




\section{INTRODUCTION}

\subsection{PURPOSE}

The purpose of this document is to describe tests performed to validate Revision 12.0 of the TMACS Monitor and Control System (TMACS) and verify that the software functions as intended by design.

\subsection{SCOPE}

This document is intended to test the software portion of TMACS. The tests will be performed on the development system. The software to be tested is the TMACS knowledge bases (KB) and the I/O driver/services. The development system will not be communicating to field equipment; instead, the field equipment is simulated using emulators or multiplexers in the lab.

\subsection{SUPPORTING DOCUMENTS}

- "Double-Shell Underground Waste Storage Tanks - Riser Survey," SD-RE-TI-093, Rev. 1, December 2, 1986.

- "Riser Configuration Document for Single-Shell Waste Tanks", SD-RE-TI-053, Rev. 8, August 22, 1991.

- "TMACS I/O Termination Point Listing", WHC-SD-WM-TI-594, Current Revision.

- "TMACS As-Built Design Document" HNF-SD-WM-SDD-079, Current Revision.

\subsection{SERVICE REQUESTS}

The following are the services requests incorporated into the TMACS software for this release.

\begin{tabular}{|l|l|}
\hline SR \# & \multicolumn{1}{|c|}{ Abbreviated Description } \\
\hline \hline 455 & Make Unit of Measure for Enrafs consistent \\
\hline 711 & Correct the Acromag remote procedure "Write Digital" \\
\hline 878 & Fix Suspect Station IO Report Abort Problem \\
\hline 879 & Fix Reports So The Number Found Matches The Number Displayed \\
\hline 880 & $\begin{array}{l}\text { Make Unacknowledge Alarms Stop Blinking when Alarm Processing } \\
\text { is Disabled }\end{array}$ \\
\hline 884 & Fix Remote Procedure Calls So Limit Of 4096 Is Not Reached \\
\hline 885 & Create a function to raise the CIU Enraf displacers on a routine basis \\
\hline 889 & 200 Inch Acromag Conversion Formula \\
\hline
\end{tabular}


HNF-3967, Rev. 5

\begin{tabular}{|l|l|}
\hline \multicolumn{1}{|c|}{ SR \# } & \multicolumn{1}{|c|}{ Abbreviated Description } \\
\hline 890 & Configure Enraf CIUs For Tank SY101 \\
\hline 891 & Change Instrument Limits for SY103 \\
\hline 892 & Support the transfer of CASS Alarms to TMACS \\
\hline 899 & Move RAWDATA Insert Process onto TMACSPROD \\
\hline 902 & Modify TMACS to insert SACS nightly readings directly. \\
\hline 903 & Update Operating System to NT 4.0 Service Pack 5 \\
\hline 914 & $\begin{array}{l}\text { Change Gauge Address for Enrafs in Tanks AX101 - AX104, } \\
\text { AY101 and AY102 }\end{array}$ \\
\hline 915 & Add Enrafs To Tanks AZ102, AZ151, B101-B112, and B201-B204 \\
\hline 916 & Change Gauge Address for Enraf in Tank AZ101 \\
\hline
\end{tabular}

\section{RESPONSIBILITIES}

Each organization participating in the conduct of this ATP will designate personnel to assume the responsibilities and duties as defined herein for their respective roles. Prior to the performance of this ATP these designees shall sign the ATP Participation Sheet.

\subsection{TEST DIRECTOR}

- Provides concurrence that the ATP may commence.

- Act as liaison between the test performance group and the test witnesses.

- Shall perform the test as described in this document.

- Record exceptions and test steps that are not performed on the ATP Exception Record sheets. Add additional Exception Record sheets as needed.

- Shall obtain final approval signatures and distribute copies of the ATP.

- Stop any test that, in the judgment of the Test Director, may cause damage to the system until the test procedure has been revised.

\subsection{TEST PERFORMANCE GROUP}

- Shall provide qualified personnel, tools and equipment required to perform test.

\subsection{TEST WITNESS AND APPROVAL PERSONNEL}


- Shall observe the testing and data recording to verify that their group's requirements are met.

If any representative of the witness and approval personnel objects to the results obtained during the acceptance test, he shall notify the Test Director. Any such notice, if not resolved directly to the representative's satisfaction, shall be recorded as an exception.

\subsection{TEST RECORDER}

- Get signatures on the Recorder's copy of the Acceptance Test Procedure Participation sheet prior to testing.

- Observe tests and record test data (if any).

- Initial every test step on the Recorder's copy as it is completed, next to the step number or table, when provided.

- Record exceptions and test steps, which are not performed on the Exception Sheet.

- Notify the Test Director of an exception at time the exception is made.

- Transfer Recorder's copy of the completed ATP with the final test results and signatures to the Test Director for Final Approval signatures and disposition.

\subsection{FINAL APPROVAL}

- Approval Personnel shall indicate, by their signature on the ATP Acceptance Record Sheet that the ATP result's are accepted. Any questions or objections shall be referred to the Test Director for resolution.

If the approval personnel find an exception to the test that is of sufficiently small magnitude, a test approval may be given. In this case, a list of such exceptions shall be entered in the exception page as "Test Approved with Exceptions," signed and dated. This signature shall indicate that the exceptions are of such a nature that a rerun of the ATP is not necessary to demonstrate that the exceptions have been adequately resolved.

\subsection{OCCUPATIONAL SAFETY AND HEALTH}

- Individuals shall perform their assigned tasks in a safe manner to protect themselves and others from undue hazards and to prevent damage to property and environment.

\section{TEST PROCEDURE CHANGE CONTROL}


Acceptance testing shall be conducted in accordance with the steps and requirements specified in this procedure. In the event minor changes are required to successfully complete the Acceptance Test Procedure the change shall be noted as an exception and testing continued, only if the change will not effect the test acceptance criteria. The exception shall be incorporated into this document in accordance with HNF-PRO-440, "Engineering Document Change Control, Requirements,"

\section{PREREQUISITES}

This section describes the prerequisites required to perform this ATP. The section contains general prerequisites that apply to this test procedure as well as specific prerequisites for individual test procedures.

\subsection{GENERAL}

The following are the prerequisites for running any of the test sections described in this procedure.

1. The Test Director should bring up G2 ${ }^{1}$ with the TMACS_Main.KB and log in using the mode "t2-user" prior to running the formal test.

2. The Test Director should bring up a $\mathrm{G} 2{ }^{\circledR}$ telewindows 2 session and log in using the mode "t2-user" prior to running the formal test.

3. The Test Director should verify that following bridges/services are started as services on WindowsNT ${ }^{\mathrm{TM}}$.

${ }^{1} \mathrm{G} 2$ is a registered trademark of the Gensym Corporation.

${ }^{2}$ Telewindows is a registered trademark of the Gensym Corporation. 
HNF-3967, Rev. 5

\begin{tabular}{|c|c|c|}
\hline Common Name & Executable & Service Name \\
\hline Acromag $^{3} \mathrm{I} / \mathrm{O}$ driver & Acromag_driver.exe & $\begin{array}{l}\text { AcromagDriver } 22200 \\
\text { AcromagDriver } 22201 \\
\text { AcromagDriver } 22202 \\
\text { AcromagDriver } 22203 \\
\text { AcromagDriver } 22204 \\
\text { AcromagDriver } 22205\end{array}$ \\
\hline Alarm Printer driver & Tmacs_printer_driver.exe & TMACSPrtDriver 22300 \\
\hline Enraf $^{(t)} \mathrm{I} / \mathrm{O}$ driver & Enraf_driver.exe & EnrafDriver 22206 \\
\hline Panalarm ${ }^{4} \mathrm{I} / \mathrm{O}$ driver & Panalm_driver.exe & PanalmDriver 22207 \\
\hline Westronic $^{5}$ //O driver & Westronic.driver & WestronicDriver 22212 \\
\hline $\mathrm{G} 2^{\infty}$ ODBC Bridge & & $\overline{\mathrm{G} 2}{ }^{\mathrm{k}} \mathrm{ODBC}$ Bridge \\
\hline
\end{tabular}

4. The Test Director shall have available the latest version of the following reference materials:

- “TMACS I/O Termination Point Listing", (WHC-SD-WM-TI-594, current revision), document written by Instrument \& Control (I\&C). The electronic version is available at $\backslash$ AP014\TMACS.

- "Riser Configuration Document for Single-Shell Waste Tanks", (SD-RE-TI-053, Rev. 8).

- Double-Shell Underground Waste Storage Tanks - Riser Survey", (SD-RE-TI-093, Rev. 1).

5. The serial multiplexers or emulators for the Acromag ${ }^{\mathrm{TM}}$, Enraf $^{(\mathbb{B})}$, Panalarm, $^{(B)}$ and Westronic $^{(1)}$ devices are available. At least one serial multiplexer (or emulator) is attached to the test computer and that the appropriate driver can function through the appropriate serial port.

\subsection{GRAPHICS}

No additional prerequisites are needed.

\subsection{TRENDING}

To give a proper display of trending it is strongly advised that 1 or more days of history files be copied from production to the system to be tested (give enough time for the files to be processed) and run into the development TMACS.

\footnotetext{
${ }^{3}$ Acromag is a trademark of Acromag Incorporated, Wixom, Michigan.

${ }^{4}$ Panalarm is a registered trademark of Ametek, Inc.

${ }^{5}$ Westronics is a registered trademark of Westronics, Inc.
} 


\subsection{REPORTS}

No additional prerequisites are needed.

\subsection{EXTERNAL INTERFACES}

No additional prerequisites are needed.

\subsection{POINT PROCESSING}

1. This test requires the system to be in a state in which no other alarm activity is generated externally. The Test Director may need to disable the collection of sensor readings from the lab equipment and clear alarm messages generated by the system start up.

2. The individual Test Cases are built using tank "Test-201", which contains one discrete and one continuous sensor. The current values for these sensors are entered programmatically; the tests assume that the following parameters have been set for sensor Continuous-200001. Verify that the sensor has the parameters in Table 1.

Table 1. Parameters for Sensor Continuous-200001

\begin{tabular}{|l|l|}
\hline \multicolumn{1}{|c|}{ Parameter } & \multicolumn{1}{c|}{ Value } \\
\hline High Instrument Limit & 22 \\
\hline High Alarm Limit & 15 \\
\hline Low Alarm Limit & 10 \\
\hline Low Instrument Limit & 4 \\
\hline Delta Band & 0.0 \\
\hline Alarm Deadband & 0.9 \\
\hline Rate of Change & 1.2 \\
\hline ROC Limit & 2.2 \\
\hline
\end{tabular}

3. Verify that the discrete sensor, Discrete-200001, has the values for the parameters listed in Table 2.

Table 2. Parameters for Sensor Discrete-200001

\begin{tabular}{|l|l|l|}
\hline State $0=$ Normal & Color $=$ Green & Annotation $=$ OPEN \\
\hline State $1=$ Alarm & Color $=$ Yellow & Annotation $=$ CLOSING \\
\hline State $2=$ Alarm & Color $=$ Red & Annotation $=$ CLOSED \\
\hline State $3=$ Normal & Color $=$ Green & Annotation = OPENING \\
\hline High Instrument Limit $>3$ & Low Instrument Limit $<0$ \\
\hline
\end{tabular}

4. To set up the tests in this section the Test Director must: 
- Load the testing knowledge base (KB)

- Bring up the Point Processing Functional Tests workspace

- Enter the test document revision number (i.e. 11.0).

5. The functional tests will be run individually in the test cases. The tester must be logged in to $\mathrm{G} 2{ }^{\mathbb{R}}$ in "administrator" mode.

\subsection{PERFORMANCE}

1. This purpose of this test section is to bench mark the production software using the development computer. The tests will be performed on the computer with the minimum TMACS processes running. The development computer will be running the following software during the test:

- WindowsNTTM and related system programs that will be running in production

- $\quad \mathrm{G} 2^{(B)}$ with the production TMACS knowledge bases. There should be no data recovery operations in place during the test!!!

- All driver services that would be running in production. None of these services should be receiving data from the field, lab, or emulators.

2. To set up the tests in this section the Test Director must:

- Acknowledge all the alarms from the startup process

- Load the testing knowledge base (KB)

- Hide all the workspaces until only the $\mathrm{G} 2{ }^{\mathbb{B}}$ background bricks appear

- Bring up the Point Processing Performance Tests workspace

- Enter the test document revision number (i.e. 11.0).

\subsection{LOGGING}

The Test Director may want to start and have the TMACS system running overnight to create the automated data files for this test.

\subsection{SERVICE REQUESTS}

\section{ACCEPTANCE CRITERIA}

\subsection{GENERAL}

The system shall provide multiple security levels that are password protected. 


\subsection{GRAPHICS}

The acceptance criteria for graphics is:

- Provide real-time display of numeric values of sensors

- Communicate with a minimum of 2 graphics CRTs

- Provide "PRINT" facility for graphic window displays.

\subsection{TRENDING}

The acceptance criteria trending is:

- Provide real-time trend graphs, with the following selected time intervals: 1 hour, 7 days.

\subsection{REPORTS}

The acceptance criteria is:

- Provide a list of active sensors that have not recorded a reading for the current day.

- Provide a list of sensors that are recording readings that are unreliable. (Status unknown)

- Provide a list of io-stations that are not reporting.

- Provide a list of Enraf ${ }^{(k)}$ sensors that are in non-operating mode.

- Provide a list of sensors that have alarm processing disabled.

- Provide a lis of sensors that have test processing enabled.

\subsection{EXTERNAL INTERFACES}

The system shall be capable of providing sensor information to the Surveillance Analysis Computer System (SACS) for sensors configured in both SACS and TMACS.

The acceptance criteria sensor conversion is:

- The system shall convert the data read by the field equipment in a user readable format.

\subsection{POINT PROCESSING}

The acceptance criteria trending is:

- Provide real-time alarming on high and low level for any analog point

- Provide alarm dead band filtering for analog points 
- Display the following alarm colors: red for highest priority, requiring immediate action; yellow for an abnormal condition requiring attention but not an immediate hazard; white for status indication; green for normal condition

- Provide alarm summary display with date, time, tag, description, alarm status with color-coding (green for normal). Remove message from display upon acknowledgement and reset/return to normal

- Display tanks and sensors with unacknowledged alarms as blinking

- Provide operator alarm acknowledgement. Acknowledgement action shall cease blinking of alarmed item

- Provide logging of alarms, return to normal, and alarm acknowledgements, to printer and to disk

- Provide alarming when error codes are returned from data acquisition system.

\subsection{PERFORMANCE}

The acceptance criteria trending is:

- The TMACS G2 ${ }^{(\mathcal{R}}$ program shall process input from 50 points per second while using less than $80 \%$ of the CPU time.

\subsection{LOGGING}

The acceptance criteria trending is:

- The system shall have the capability to log any sensor value

- A sensor logging shall include the time stamp and the sensor's value.

\subsection{SERVICE REQUESTS}

The acceptance criteria for the service request (SR) are contained in the description of the SR. The test director will have available a copy of the service request for viewing. 
HNF-3967, Rev. 5

\section{TEST PROCEDURES}

\subsection{GENERAL}

\subsubsection{Startup}

Note: The Test Director prior to witness testing may have completed this test.

\begin{tabular}{|c|l|l|l|}
\hline Step & \multicolumn{1}{|c|}{ Perform } & \multicolumn{1}{c|}{ Verify } & Initial \\
\hline 1. & $\begin{array}{l}\text { Start TMACS and log in as } \\
\text { 22-user. }\end{array}$ & $\begin{array}{l}\text { Verify the TMACS starts up (approximately ten } \\
\text { minutes) and verify the following: }\end{array}$ & \\
& & $\begin{array}{l}\text { A message is displayed indicating what days } \\
\text { worth of data is being recovered. } \\
\text { A status bar is displayed indicating what } \\
\text { percentage of the days readings have been } \\
\text { read into memory. }\end{array}$ & \\
& & & \\
\hline
\end{tabular}

\subsubsection{Security (Telewindows ${ }^{\circledR}$ and Central Console)}

\begin{tabular}{|c|c|c|c|}
\hline Step & Action & Verify & Initial \\
\hline 1. & $\begin{array}{l}\text { Attempt to } \log \text { in as t2-user } \\
\text { using a 'G2 } 2^{(i)} \text { user mode' } \\
\text { other than t2-user or shut } \\
\text { down. } \\
\text { (i.e. "administrator".) }\end{array}$ & $\begin{array}{l}\text { Verify that TMACS does not enter selected } \\
\text { mode. }\end{array}$ & \\
\hline 2. & $\begin{array}{l}\text { Log in as t2-user using the } \\
\text { 'G2 } 2^{(1)} \text { user mode' as "t2- } \\
\text { user". }\end{array}$ & $\begin{array}{l}\text { Verify that the user mode selection workspace } \\
\text { disappears from the screen (indicating a } \\
\text { successful login). }\end{array}$ & \\
\hline
\end{tabular}

\subsection{GRAPHICS}

This section is performed after the system has been started and the clock is functional. This test should be performed on both the main console and Telewindows ${ }^{\text {BD }}$.

\subsubsection{Main Display}

\begin{tabular}{|l|l|l|l|}
\hline Step & \multicolumn{1}{|c|}{ Action } & \multicolumn{1}{|c|}{ Verify } & Initial \\
\hline \multicolumn{1}{|c|}{} & \multicolumn{1}{|c|}{ Main Display } \\
\hline 1. & $\begin{array}{l}\text { Click on the Show Main } \\
\text { Display button on the } \\
\text { Control Panel. }\end{array}$ & $\begin{array}{l}\text { Verify that the following workspaces appear on } \\
\text { the screen: } \\
\text { - Control Panel. }\end{array}$ & \\
\hline
\end{tabular}


HNF-3967, Rev. 5

\begin{tabular}{|c|c|c|c|}
\hline Step & Action & Verify & Initial \\
\hline & & $\begin{array}{l}\text { - Monitored Systems } \\
\text { - Most Recent Alarm. } \\
\text { - Hanford Tank Farm Facilities } \\
\text { Note: Working window (may appear if Data } \\
\text { Recovery is still running) }\end{array}$ & \\
\hline 2. & $\begin{array}{l}\text { Attempt to move several } \\
\text { objects chosen at random } \\
\text { on the workspace by doing } \\
\text { a click-and-drag. }\end{array}$ & Verify that they do not move. & \\
\hline 3. & $\begin{array}{l}\text { Click anywhere in the } \\
\text { empty space on each } \\
\text { workspace. }\end{array}$ & Verify that no menus appear. & \\
\hline
\end{tabular}

\subsubsection{Control Panel}

\subsubsection{General}

\begin{tabular}{|l|l|l|c|}
\hline Step & \multicolumn{1}{|c|}{ Action } & \multicolumn{1}{|c|}{ Verify } & \multicolumn{1}{|c|}{ Initial } \\
\hline 1. & $\begin{array}{l}\text { Using a Tank Status } \\
\text { display, cover a portion of } \\
\text { the Control Panel } \\
\text { workspace. }\end{array}$ & $\begin{array}{l}\text { Verify that the Control Panel is brought to the } \\
\text { top. } \\
\text { Click on the background of } \\
\text { the Control Panel } \\
\text { workspace. }\end{array}$ & \\
\hline
\end{tabular}

\subsubsection{Operation of the SHOW MAIN DISPLAY button}

\begin{tabular}{|c|c|c|c|}
\hline Step & Perform & Expected Result & Initial \\
\hline 1. & $\begin{array}{l}\text { Display a least one of each } \\
\text { of following status } \\
\text { workspaces: } \\
\text { - Tank Status } \\
\text { - Farm Status } \\
\text { - Between-Farm Status } \\
\text { - Monitor System Status } \\
\text { Then click on the Show } \\
\text { Main Display button on the } \\
\text { Contol Panel workspace. }\end{array}$ & $\begin{array}{l}\text { Verify the Tank Status workspace disappears } \\
\text { and that the following workspaces appear on } \\
\text { the screen and are in the proper locations: } \\
\text { - Hanford Tank Farm Facilities } \\
\text { - Control Panel } \\
\text { - Most Recent Alarm (may be partially } \\
\text { covered by the Hanford Tank Farm } \\
\text { Facilities workspace) } \\
\text { - Monitored Systems } \\
\text { Note: Working window may appear if Data } \\
\text { Recovery is still running. }\end{array}$ & \\
\hline
\end{tabular}




\subsubsection{Operation of CURRENT ALARMS Button and Screen}

Note: The CURRENT ALARMS button is not available in a Telewindows ${ }^{\boxplus}$ session.

\begin{tabular}{|c|c|c|c|}
\hline Step & Perform & Expected Result & Initial \\
\hline 1. & $\begin{array}{l}\text { Click on the CURRENT } \\
\text { ALARMS button on the } \\
\text { Control Panel. }\end{array}$ & $\begin{array}{l}\text { Verify that the Current Alarms workspace } \\
\text { appears on the left-hand side of the screen and } \\
\text { includes the following: } \\
\text { - HIDE WINDOW (with an } \mathrm{x} \text { as a symbol) } \\
\text { - } \text { SHRINK WINDOW (an as a symbol) } \\
\text { - } \text { EXPAND WINDOW (an } \mathbf{4} \text { as a symbol) } \\
\text { - } \text { CURRENT-ALARMS title box } \\
\text { - UP ONE ALARM } \\
\text { - } \text { REFRESH ALARMS } \\
\text { - DOWN ONE PAGE } \\
\text { - } \text { DOWN ONE ALARM } \\
\text { - GO TO TOP of LIST } \\
\text { - ACKNOWD Of LIST } \\
\text { - ALARMS } \\
\text { ACKNOWLEDGE ALL BLUE } \\
\text { MESSAGES }\end{array}$ & \\
\hline \multicolumn{4}{|c|}{ Operation of the SHRINK WINDOW button } \\
\hline 2. & $\begin{array}{l}\text { Note: If the Current } \\
\text { Alarms workspace is } \\
\text { already shrunk then } \\
\text { expand first. } \\
\text { Click on the SHRINK } \\
\text { WINDOW button. }\end{array}$ & $\begin{array}{l}\text { Verify the Current Alarms workspace: } \\
\text { - Decreases in size } \\
\text { - Moves to the left-hand side of the screen } \\
\text { - Has space to show } 10 \text { alarms. (Only } \\
9 \text { alarms will be visible if the first alarm in } \\
\text { the list is visible.) }\end{array}$ & \\
\hline \multicolumn{4}{|c|}{ Operation of the EXPAND WINDOW button } \\
\hline 3. & $\begin{array}{l}\text { Click on the EXPAND } \\
\text { WINDOW button. }\end{array}$ & $\begin{array}{l}\text { Verify the Current Alarms workspace: } \\
\text { - Increases in size } \\
\text { - Moves to the left-hand side of the screen } \\
\text { - Has space to show } 6 \text { alarms. (Only } \\
5 \text { alarms will be visible if the first alarm in } \\
\text { the list is visible.) }\end{array}$ & \\
\hline \multicolumn{4}{|c|}{ Operation of the Page buttons } \\
\hline 4. & $\begin{array}{l}\text { Select each of the } \\
\text { following buttons: } \\
\text { - GO TO END }\end{array}$ & Verify each button operates correctly. & \\
\hline
\end{tabular}


HNF-3967, Rev. 5

\begin{tabular}{|c|c|c|c|}
\hline Step & Perform & Expected Result & Initial \\
\hline & $\begin{array}{ll}\text { - } & \text { GO TO TOP } \\
\text { - } & \text { DOWN ONE PAGE } \\
\text { - } & \text { UP ONE PAGE } \\
\text { - } & \text { DOWN ONE ALARM } \\
\text { - } & \text { UP ONE ALARM } \\
\text { - } & \text { REFRESH ALARMS } \\
\end{array}$ & & \\
\hline \multicolumn{4}{|c|}{ Operation of the ALL WHITE ALARMS button } \\
\hline 5. & $\begin{array}{l}\text { Click on the Acknowledge } \\
\text { ALL WHITE ALARMS } \\
\text { button. } \\
\text { (Note: May have to } \\
\text { generate white alarms } \\
\text { first) }\end{array}$ & $\begin{array}{l}\text { Verify the white alarms disappear from the } \\
\text { alarm list and that the Number of Current } \\
\text { Alarms is updated appropriately. }\end{array}$ & \\
\hline \multicolumn{4}{|c|}{ Operation of the ALL BLUE MESSAGES button } \\
\hline 6. & $\begin{array}{l}\text { Click on the Acknowledge } \\
\text { ALL BLUE MESSAGES } \\
\text { button. } \\
\text { (Note: May have to } \\
\text { generate blue alarms first) }\end{array}$ & $\begin{array}{l}\text { Verify the blue messages disappear from the } \\
\text { alarm list. }\end{array}$ & \\
\hline \multicolumn{4}{|c|}{ Operation of the HIDE WINDOW button } \\
\hline 7. & $\begin{array}{l}\text { Click on the HIDE } \\
\text { WINDOW button }\end{array}$ & Verify that the workspace disappears & \\
\hline
\end{tabular}

\subsubsection{Operation of the HIDE SENSOR TRENDS button}

\begin{tabular}{|c|c|c|c|}
\hline Step & Perform & Expected Result & Initial \\
\hline 1. & $\begin{array}{l}\text { Display several sensor } \\
\text { trend workspaces (graph, } \\
\text { details, history) selected at } \\
\text { random. } \\
\text { Click on the HIDE } \\
\text { SENSOR TRENDS button } \\
\text { on the Control Panel. }\end{array}$ & $\begin{array}{l}\text { Verify that Sensor Trend workspaces for the } \\
\text { selected sensors appear. }\end{array}$ & \\
\hline
\end{tabular}




\subsubsection{Operation of the REPORTS button}

(Note: The verification of the reports is performed elsewhere in this document.)

\begin{tabular}{|c|c|c|c|}
\hline Step & Perform & $\begin{array}{c}\text { Expected Result } \\
\end{array}$ & Initial \\
\hline 1. & $\begin{array}{l}\text { Click on the REPORT } \\
\text { MENU button on the } \\
\text { Control Panel. }\end{array}$ & $\begin{array}{l}\text { Verify that the Report Menu workspace is } \\
\text { displayed with a list of report buttons that } \\
\text { includes the following: } \\
\text { - Suspect Sensor Report } \\
\text { - Suspect IO-Station Report } \\
\text { - Unknown Sensor Report } \\
\text { - ENRAF Non-Operating Mode Report } \\
\text { - Sensor Disable Alarm Report } \\
\text { - Sensor Enabled Test Report }\end{array}$ & \\
\hline 2. & $\begin{array}{l}\text { Select a report at random. } \\
\text { Click on the Title of the } \\
\text { report. }\end{array}$ & $\begin{array}{l}\text { Verify the Help workspace for the chosen } \\
\text { report is displayed. }\end{array}$ & \\
\hline 3. & Click on the HIDE button. & Verify the workspace disappears. & \\
\hline 4. & $\begin{array}{l}\text { Select a report at random } \\
\text { Click on the button for the } \\
\text { chosen report. }\end{array}$ & $\begin{array}{l}\text { Verify the chosen report's workspace is } \\
\text { displayed. }\end{array}$ & \\
\hline 5. & Click on the HIDE button. & Verify the workspace disappears. & \\
\hline 6. & $\begin{array}{l}\text { Click on the HIDE button } \\
\text { on Report Menu } \\
\text { workspace. }\end{array}$ & Verify the workspace disappears. & \\
\hline
\end{tabular}

\subsubsection{Hanford Tank Farm Facility}

\begin{tabular}{|c|c|c|c|}
\hline Step & Action & Verify & Initial \\
\hline 1. & $\begin{array}{l}\text { On the HTFF workspace, } \\
\text { click on a tank icon for any } \\
\text { active tank. }\end{array}$ & $\begin{array}{l}\text { Verify that the selected Tank Status workspace } \\
\text { appears. }\end{array}$ & \\
\hline 2. & $\begin{array}{l}\text { On the HTFF workspace, } \\
\text { click on a farm icon (farm } \\
\text { id surrounded by a box) for } \\
\text { any active farm. }\end{array}$ & $\begin{array}{l}\text { Verify that the selected Farm Status workspace } \\
\text { appears. }\end{array}$ & \\
\hline 3. & $\begin{array}{l}\text { On the HTFF workspace, } \\
\text { click on a between farm } \\
\text { icon (i.e. } 204 \text {-A surrounded } \\
\text { by a box) for any active } \\
\text { between farm. }\end{array}$ & $\begin{array}{l}\text { Verify that the selected Between Farm Status } \\
\text { workspace appears. }\end{array}$ & \\
\hline
\end{tabular}




\subsubsection{Operation of a TANK ICON button}

\begin{tabular}{|c|c|c|c|}
\hline Step & Perform & Expected Result & Initial \\
\hline 1. & $\begin{array}{l}\text { Click any enabled Tank } \\
\text { Icon in the Hanford Tank } \\
\text { Farm Facilities. (The icon } \\
\text { will not be gray.) }\end{array}$ & $\begin{array}{l}\text { Verify that the Tank Status workspace appears } \\
\text { on the screen and contains the following: } \\
\text { - TITLE (correctly identifying the tank) } \\
\text { - HIDE WINDOW button (x as a symbol) } \\
\text { - SHRINK WINDOW button (an } \boldsymbol{\nabla} \text { as a } \\
\text { symbol) } \\
\text { - EXPAND WINDOW button (an } \boldsymbol{\Delta} \text { as a } \\
\text { symbol) } \\
\text { - ACK ALARMS button } \\
\text { - UPDATE button (if available, not all tanks } \\
\text { - have discrete sensors). } \\
\text { - Riser Location Drawing (Refer to the } \\
\text { appropriate Tank Riser Configuration } \\
\text { Documents for correct location) } \\
\text { - Print Screen button } \\
\text { - Riser Identifier(s) (displayed over the } \\
\text { - Senser(s)) } \\
\text { - User Selectable Trend button(s). }\end{array}$ & \\
\hline \multicolumn{4}{|c|}{ Thermocouple Operation } \\
\hline 2. & $\begin{array}{l}\text { Use the document } \\
\text { "TMACS I/O Termination } \\
\text { Point Listing" (Tag list) as } \\
\text { a reference. Choose a } \\
\text { thermocouple for the tank. }\end{array}$ & $\begin{array}{l}\text { Verify the following: } \\
\text { - The thermocouple is positioned on the tank } \\
\text { display in a way that approximates the } \\
\text { physical location in the tank. } \\
\text { - Sensor label and current value are displayed } \\
\text { next to the thermocouple icon } \\
\text { - Sensor icon is overlaid with the sensor } \\
\text { alarm status color }\end{array}$ & \\
\hline \multicolumn{4}{|c|}{ Operation of Tank Level Indication } \\
\hline 3. & $\begin{array}{l}\text { Use the document } \\
\text { "TMACS I/O Termination } \\
\text { Point Listing" (Tag list) as } \\
\text { a reference. Choose a } \\
\text { surface level sensor for the } \\
\text { tank. }\end{array}$ & $\begin{array}{l}\text { Verify the following: } \\
\text { - The surface level icon(s) is positioned } \\
\text { proportionally to the maximum tank height } \\
\text { and at the current level displayed by the } \\
\text { reading. } \\
\text { - Sensor label and current value are displayed } \\
\text { next to the surface level icon. The label } \\
\text { should identify the source of this reading. } \\
\text { (ENRAF } F^{00} \text { or } S A C S \text { ) } \\
\text { - Sensor icon is overlaid with the sensor } \\
\text { alarm status color }\end{array}$ & \\
\hline
\end{tabular}




\begin{tabular}{|c|c|c|c|}
\hline Step & Perform & Expected Result & Initial \\
\hline \multicolumn{4}{|c|}{$\begin{array}{l}\text { Operation of Print button } \\
\text { Not available in a Telewindows }{ }^{\circledR} \text { session }\end{array}$} \\
\hline 4. & $\begin{array}{l}\text { Click on the PRINT } \\
\text { SCREEN button. }\end{array}$ & Verify that the tank workspace prints. & \\
\hline \multicolumn{4}{|c|}{ Operation of Shrink Window button } \\
\hline 5. & $\begin{array}{l}\text { Click on the SHRINK } \\
\text { WINDOW button (an } \nabla \text { as } \\
\text { a symbol). }\end{array}$ & Verify that the workspace shrinks. & \\
\hline 6. & $\begin{array}{l}\text { Drag the Tank Status } \\
\text { workspace to the upper } \\
\text { right hand corner. }\end{array}$ & $\begin{array}{l}\text { Verify that the Tank Status workspace stops at } \\
\text { the edge of the screen when dragged to the top } \\
\text { or to the right. }\end{array}$ & \\
\hline \multicolumn{4}{|c|}{ Operation of Expand Window button } \\
\hline 7. & $\begin{array}{l}\text { Click on the EXPAND } \\
\text { WINDOW button (an } \\
\text { as a symbol). }\end{array}$ & Verify that the workspace enlarges. & \\
\hline \multicolumn{4}{|c|}{ Operation of the HIDE button } \\
\hline 8 . & $\begin{array}{l}\text { Click on the HIDE } \\
\text { WINDOW. }\end{array}$ & Verify that the workspace is hidden. & \\
\hline $\begin{array}{l}\text { Note: } \\
\text { Alarm }\end{array}$ & $\begin{array}{l}\text { Dperation of the Acknowledg } \\
\text { Tests) }\end{array}$ & Alarm button is performed in section $6.6 .7(\mathrm{Mi}$ & \\
\hline
\end{tabular}

\subsubsection{Operation of a Farm ICON button}

\begin{tabular}{|c|c|c|c|}
\hline Step & Perform & Expected Result & Initial \\
\hline 1. & $\begin{array}{l}\text { Click any enabled Farm } \\
\text { Icon (tank farm label } \\
\text { surrounded by a box) on } \\
\text { the Hanford Tank Farm } \\
\text { Facilities workspace. (The } \\
\text { icon will not be gray.) }\end{array}$ & $\begin{array}{l}\text { Verify that the Farm Status workspace appears } \\
\text { on the screen and contains the following: } \\
\text { - TITLE (correctly identifying the farm) } \\
\text { - HIDE WINDOW button ( } \mathrm{x} \text { as a symbol) } \\
\text { - SHRINK WINDOW button (an } \nabla \text { as a } \\
\text { symbol) } \\
\text { - EXPAND WINDOW button (an } \boldsymbol{\Delta} \text { as a } \\
\text { - } \text { Pymbol) } \\
\text { - ALINT SCREEN button (P as a symbol) } \\
\text { ALAR GROUP buttons }\end{array}$ & \\
\hline 2. & $\begin{array}{l}\text { Click any enabled } \\
\text { ALARM GROUP button } \\
\text { (The button will not be } \\
\text { gray). } \\
\text { If a Sub-Alarm Group } \\
\text { workspace appears then }\end{array}$ & $\begin{array}{l}\text { Verify that the Panel Status (or Panel Section } \\
\text { Status) workspace appears on the screen and } \\
\text { contains the following: } \\
\text { - TITLE (correctly identifying the farm) } \\
\text { - HIDE WINDOW button ( } \mathrm{x} \text { as a symbol) }\end{array}$ & \\
\hline
\end{tabular}




\begin{tabular}{|c|c|c|c|}
\hline Step & Perform & Expected Result & Initial \\
\hline & $\begin{array}{l}\text { click any enabled SUB- } \\
\text { ALARM GROUP buttons. } \\
\text { Repeat until the panel (or } \\
\text { section panel status) screen } \\
\text { appears. }\end{array}$ & $\begin{array}{ll}\text { - } & \text { SHRINK WINDOW button (an } \boldsymbol{\nabla} \text { as a } \\
& \text { symbol) } \\
\text { - } & \text { EXPAND WINDOW button (an } \boldsymbol{\Delta} \text { as a } \\
& \text { symbol) } \\
\text { - } & \text { PRINT SCREEN button (P as a symbol) } \\
\text { - } & \text { ACK ALARMS } \\
\text { - } & \text { UPDATE button (U as a symbol) (optional) } \\
\text { - } & \text { ALARM PANEL }\end{array}$ & \\
\hline 3. & $\begin{array}{l}\text { Use the document } \\
\text { "TMACS I/O Termination } \\
\text { Point Listing" (Tag list) as } \\
\text { a reference. Choose a } \\
\text { discrete sensor for the } \\
\text { panel. }\end{array}$ & $\begin{array}{l}\text { Verify the following: } \\
\text { - Sensor is in correct location in the panel. } \\
\text { Description for the sensor is correct or the } \\
\text { window text is correct. }\end{array}$ & \\
\hline \multicolumn{4}{|c|}{$\begin{array}{c}\text { Operation of Print button } \\
\text { Not available in a Telewindows }{ }^{\mathbb{B}} \text { session } \\
\end{array}$} \\
\hline 4. & $\begin{array}{l}\text { Click on the PRINT } \\
\text { SCREEN button. }\end{array}$ & Verify that the workspace prints. & \\
\hline \multicolumn{4}{|c|}{ Operation of Shrink Window button } \\
\hline 5. & $\begin{array}{l}\text { Click on the SHRINK } \\
\text { WINDOW button (an } \nabla \text { as } \\
\text { a symbol). }\end{array}$ & Verify that the workspace shrinks. & \\
\hline 6. & $\begin{array}{l}\text { Drag the Tank Status } \\
\text { workspace to the upper } \\
\text { right hand corner. }\end{array}$ & $\begin{array}{l}\text { Verify that the Tank Status workspace stops at } \\
\text { the edge of the screen when dragged to the top } \\
\text { or to the right. }\end{array}$ & \\
\hline \multicolumn{4}{|c|}{ Operation of Expand Window button } \\
\hline 7. & $\begin{array}{l}\text { Click on the EXPAND } \\
\text { WINDOW button (an } \\
\text { as a symbol). }\end{array}$ & Verify that the workspace enlarges. & \\
\hline \multicolumn{4}{|c|}{ Operation of the HIDE button } \\
\hline 8. & $\begin{array}{l}\text { Click on the HIDE } \\
\text { WINDOW. }\end{array}$ & Verify that the workspace is hidden. & \\
\hline
\end{tabular}




\subsubsection{Operation of a Between Farm ICON button}

\begin{tabular}{|c|c|c|c|}
\hline Step & Perform & Expected Result & Initial \\
\hline 1. & $\begin{array}{l}\text { Click any enabled Between } \\
\text { Farm Icon (tank farm label } \\
\text { surrounded by a box) on } \\
\text { the Hanford Tank Farm } \\
\text { Facilities workspace. (The } \\
\text { icon will not be gray.) }\end{array}$ & $\begin{array}{l}\text { Verify that the Between Farm Status workspace } \\
\text { appears on the screen and contains the } \\
\text { following: } \\
\text { - TITLE (correctly identifying the farm) } \\
\text { - HIDE WINDOW button ( } \mathrm{x} \text { as a symbol) } \\
\text { - SHRINK WINDOW button (an } \nabla \text { as a } \\
\text { symbol) } \\
\text { EXPAND WINDOW button (an } \Delta \text { as a } \\
\text { - } \text { Pymbol) } \\
\text { - } \text { ALART SCREEN button (P as a symbol) }\end{array}$ & \\
\hline 2. & $\begin{array}{l}\text { Click any enabled } \\
\text { ALARM GROUP button } \\
\text { (The button will not be } \\
\text { gray). } \\
\text { If a Sub-Alarm Group } \\
\text { workspace appears then } \\
\text { click any enabled SUB- } \\
\text { ALARM GROUP buttons. } \\
\text { Repeat until the panel (or } \\
\text { section panel status) screen } \\
\text { appears. }\end{array}$ & $\begin{array}{l}\text { Verify that the Panel Status (or Panel Section } \\
\text { Status) workspace appears on the screen and } \\
\text { contains the following: } \\
\text { - TITLE (correctly identifying the farm) } \\
\text { - HIDE WINDOW button ( } \mathrm{x} \text { as a symbol) } \\
\text { - SHRINK WINDOW button (an } \mathbf{\nabla} \text { as a } \\
\text { - } \text { Symbol) } \\
\text { EXPAND WINDOW button (an } \mathbf{A} \text { as a } \\
\text { - } \text { Pymbol) } \\
\text { - } \text { ACK ALARM SCREEN button (P as a symbol) } \\
\text { - UPDATE button (U as a symbol) (optional) } \\
\text { - ALARM PANEL }\end{array}$ & \\
\hline 3. & $\begin{array}{l}\text { Use the document } \\
\text { "TMACS I/O Termination } \\
\text { Point Listing" (Tag list) as } \\
\text { a reference. Choose a } \\
\text { discrete sensor for the } \\
\text { panel. }\end{array}$ & $\begin{array}{l}\text { Verify the following: } \\
\text { - Sensor is in correct location in the panel. } \\
\text { - Description for the sensor is correct or } \\
\text { window text is correct. }\end{array}$ & \\
\hline \multicolumn{4}{|c|}{$\begin{array}{c}\text { Operation of Print button } \\
\text { Not available in a Telewindows }{ }^{\circledR} \text { session }\end{array}$} \\
\hline 4. & $\begin{array}{l}\text { Click on the PRINT } \\
\text { SCREEN button. }\end{array}$ & Verify that the workspace prints. & \\
\hline \multicolumn{4}{|c|}{ Operation of Shrink Window button } \\
\hline 5. & $\begin{array}{l}\text { Click on the SHRINK } \\
\text { WINDOW button (an } \nabla \text { as } \\
\text { a symbol). }\end{array}$ & Verify that the workspace shrinks. & \\
\hline
\end{tabular}


HNF-3967, Rev. 5

\begin{tabular}{|c|c|c|c|}
\hline Step & Perform & Expected Result & Initial \\
\hline 6. & $\begin{array}{l}\text { Drag the Tank Status } \\
\text { workspace to the upper } \\
\text { right hand corner. }\end{array}$ & $\begin{array}{l}\text { Verify that the Tank Status workspace stops at } \\
\text { the edge of the screen when dragged to the top } \\
\text { or to the right. }\end{array}$ & \\
\hline \multicolumn{4}{|c|}{ Operation of Expand Window button } \\
\hline 7. & $\begin{array}{l}\text { Click on the EXPAND } \\
\text { WINDOW button (an } \\
\text { as a symbol). }\end{array}$ & Verify that the workspace enlarges. & \\
\hline \multicolumn{4}{|c|}{ Operation of the HIDE button } \\
\hline 8. & $\begin{array}{l}\text { Click on the HIDE } \\
\text { WINDOW. }\end{array}$ & Verify that the workspace is hidden. & \\
\hline
\end{tabular}

\subsubsection{Operation Of The HTFF Print Button}

Note: The CURRENT ALARMS button is not available in a Telewindows $®$ session.

\begin{tabular}{|l|l|l|c|}
\hline Step & \multicolumn{1}{|c|}{ Perform } & \multicolumn{1}{|c|}{ Expected Result } & Initial \\
\hline 1. & $\begin{array}{l}\text { Click on the PRINT } \\
\text { SCREEN button in the } \\
\text { lower right hand corner of } \\
\text { workspace. (May have to } \\
\text { click on HTTF workspace } \\
\text { to see button) }\end{array}$ & Verify that the workspace is printed. & \\
\hline
\end{tabular}

\subsubsection{Monitored Systems Display}

\subsubsection{Operation Of The Monitored System Button}

\begin{tabular}{|c|c|c|c|}
\hline Step & Perform & Expected Result & Initial \\
\hline 1. & $\begin{array}{l}\text { Click on the any system } \\
\text { displayed on the } \\
\text { MONITORED SYSTEMS } \\
\text { workspace. }\end{array}$ & $\begin{array}{l}\text { Verify that a workspace is displayed } \\
\text { representing the monitored system. }\end{array}$ & \\
\hline 2. & $\begin{array}{l}\text { Click on the sensor } \\
\text { objects. }\end{array}$ & $\begin{array}{l}\text { Verify that no graphic workspaces or menu } \\
\text { boxes are displayed. }\end{array}$ & \\
\hline 3. & $\begin{array}{l}\text { For alarm panels, click on } \\
\text { any graphic "borders". }\end{array}$ & $\begin{array}{l}\text { Verify that no graphic workspaces or menu } \\
\text { boxes are displayed. }\end{array}$ & \\
\hline \multicolumn{4}{|c|}{ Operation of Shrink Window button } \\
\hline & $\begin{array}{l}\text { Click on the SHRINK } \\
\text { WINDOW button (an } \boldsymbol{\nabla} \text { as } \\
\text { a symbol). }\end{array}$ & Verify that the workspace shrinks. & \\
\hline
\end{tabular}


HNF-3967, Rev. 5

\begin{tabular}{|c|c|c|c|}
\hline Step & Perform & Expected Result & Initial \\
\hline & $\begin{array}{l}\text { Drag the workspace to the } \\
\text { upper right hand corner. }\end{array}$ & $\begin{array}{l}\text { Verify that the workspace stops at the edge of } \\
\text { the screen when dragged to the top or to the } \\
\text { right. }\end{array}$ & \\
\hline \multicolumn{4}{|c|}{ Operation of Expand Window button } \\
\hline & $\begin{array}{l}\text { Click on the EXPAND } \\
\text { WINDOW button (an } \\
\text { as a symbol). }\end{array}$ & Verify that the workspace enlarges. & \\
\hline \multicolumn{4}{|c|}{ Operation of the HIDE button } \\
\hline & $\begin{array}{l}\text { Click on the HIDE } \\
\text { WINDOW. }\end{array}$ & Verify that the workspace is hidden. & \\
\hline
\end{tabular}

\subsection{TRENDING}

This section describes the test cases for both the individual and user selectable trends.

Have the Test Director verify that the TMACS is running in Development Mode of operation and is generating variable sensor data. Note: $\mathrm{G} 2{ }^{(k)}$ will only display trend data that varies over time.

\subsubsection{Operation of Individual Sensor Trends}

This section describes the test cases for the individual selectable trends.

\subsubsection{Operation of Trend Chart}

\begin{tabular}{|c|c|c|c|}
\hline Step & Perform & Expected Result & Initial \\
\hline 1. & $\begin{array}{l}\text { Click any enabled Tank Icon } \\
\text { in the Hanford Tank Farm } \\
\text { Facilities. (The icon will not } \\
\text { be gray.) } \\
\text { Click on the portion of any } \\
\text { sensor icon that looks like a } \\
\text { little chart. }\end{array}$ & $\begin{array}{l}\text { Verify that a Sensor Trend workspace for the } \\
\text { sensor chosen and contains the following. } \\
\text { - Chart } \\
\text { - HIDE WINDOW }(X) \text { button } \\
\text { - DETAIL }(D) \text { button. } \\
\text { - PRINT }(P) \text { button } \\
\text { - TREND CHART }\end{array}$ & \\
\hline 2. & Examine the Chart. & $\begin{array}{l}\text { Verify the following: } \\
\text { - The values line color is black. } \\
\text { - Lines for the low and high alarm limits } \\
\text { appear at roughly one-tenth }(1 / 10) \text { and } \\
\text { nine tenths }(9 / 10) \text { of the distance on the } \\
\text { vertical axis. Note: Only if trend is } \\
\text { within limits. } \\
\text { - Alarm limit bands match the alarm color }\end{array}$ & \\
\hline
\end{tabular}


HNF-3967, Rev. 5

\begin{tabular}{|l|l|l|l|}
\hline Step & \multicolumn{1}{|c|}{ Perform } & \multicolumn{1}{c|}{ Expected Result } & Initial \\
\hline & & $\begin{array}{l}\text { (Yellow or Red) } \\
\text { The trend title (above) and label (below) } \\
\text { agree with the sensor tag name and } \\
\text { descriptor. } \\
\text { The time scale of the horizontal time axis } \\
\text { is 7 days and that some dates are shown. }\end{array}$ & \\
\hline 3. & Click on the Print button. & $\begin{array}{l}\text { Verify the Sensor Trend workspace is } \\
\text { printed. }\end{array}$ & \\
\hline 4. & Click on the HIDE & Verify that the workspace is hidden. & \\
\hline
\end{tabular}

\subsubsection{Operation of Sensor Details}

\begin{tabular}{|c|c|c|c|c|}
\hline Step & Perform & \multicolumn{2}{|c|}{ Expected Result } & Innitial \\
\hline 1. & $\begin{array}{l}\text { Select a } \\
\text { continuous sensor } \\
\text { that has polling } \\
\text { enabled at random. } \\
\text { Display the } \\
\text { individual sensor } \\
\text { trend chart for the } \\
\text { chosen sensor. }\end{array}$ & \multicolumn{2}{|c|}{$\begin{array}{l}\text { Verify the trend chart is displayed and the tag name is } \\
\text { displayed above the trend chart }\end{array}$} & \\
\hline 2. & $\begin{array}{l}\text { Click on the } \\
\text { Details (D) button. }\end{array}$ & \multicolumn{2}{|c|}{$\begin{array}{l}\text { Verify the Sensor Details workspace for the chosen sensor } \\
\text { is displayed with the following information: } \\
\text { - Hide }(X) \text { button } \\
\text { - Print (P) button } \\
\text { - Update }(U) \text { button } \\
\text { - Test }(T) \text { button } \\
\text { - } \\
\text { (Note: Sensor must have point processing enabled for the } \\
\text { Test buttons to be displayed.) } \\
\text { And depending on the sensor type one of the following } \\
\text { sensor information groups. }\end{array}$} & \\
\hline \multicolumn{5}{|c|}{ Temperature Sensor } \\
\hline & & $\begin{array}{l}\text { Current Reading } \\
\text { Last Good Reading } \\
\text { Quality Status } \\
\text { Units } \\
\text { High Alarm Limit } \\
\text { Low Alarm Limit }\end{array}$ & $\begin{array}{l}\text { Last Update Method } \\
\text { Test Processing } \\
\text { Type } \\
\text { Upper Instrument Limit } \\
\text { Lower Instrument Limit }\end{array}$ & \\
\hline
\end{tabular}


HNF-3967, Rev. 5

\begin{tabular}{|c|c|c|c|c|}
\hline Step & Perform & \multicolumn{2}{|c|}{ Expected Result } & Initial \\
\hline & . & $\begin{array}{l}\text { Deadband } \\
\text { Point Processing } \\
\text { ROC Processing } \\
\text { Station Status } \\
\text { Polling Freq. Index } \\
\text { Validity Interval } \\
\text { Expiration Time } \\
\text { Formula Expression } \\
\text { Formula Parameter }\end{array}$ & $\begin{array}{l}\text { Delta } \\
\text { Alarm Processing } \\
\text { Logging } \\
\text { Raw Value } \\
\text { Polling. Freq. Sec. }\end{array}$ & \\
\hline \multicolumn{5}{|c|}{ SACS LEVEL Sensor } \\
\hline & & $\begin{array}{l}\text { Current Reading } \\
\text { Last Good Reading } \\
\text { Quality Status } \\
\text { Units } \\
\text { High Alarm Limit } \\
\text { Low Alarm Limit } \\
\text { Deadband } \\
\text { Point Processing } \\
\text { ROC Processing } \\
\text { Suspect Status } \\
\text { Sensor Type Name } \\
\text { Slvl_dttm }\end{array}$ & $\begin{array}{l}\text { Last Update Method } \\
\text { Test Processing } \\
\text { Upper Instrument Limit } \\
\text { Lower Instrument Limit } \\
\text { Delta } \\
\text { Alarm Processing } \\
\text { Logging }\end{array}$ & \\
\hline \multicolumn{5}{|c|}{ ENRAF LEVEL Sensor } \\
\hline & & $\begin{array}{l}\text { Current Reading } \\
\text { Last Good Reading } \\
\text { Quality Status } \\
\text { Units } \\
\text { High Alarm Limit } \\
\text { Low Alarm Limit } \\
\text { Deadband } \\
\text { Point Processing } \\
\text { ROC Processing } \\
\text { Station Status } \\
\text { Polling Freq. Index } \\
\text { Displacer Position } \\
\text { Level Status } \\
\text { Alarm Status } \\
\text { Validity Interval } \\
\text { Expiration Time } \\
\text { Formula Expression } \\
\text { Formula Parameter }\end{array}$ & $\begin{array}{l}\text { Last Update Method } \\
\text { Test Processing } \\
\text { Upper Instrument Limit } \\
\text { Lower Instrument Limit } \\
\text { Delta } \\
\text { Alarm Processing } \\
\text { Logging } \\
\text { Raw Value } \\
\text { Polling. Freq. Sec. } \\
\text { Waste Level } \\
\text { Level Status Mode } \\
\text { Alarm Status Mode }\end{array}$ & \\
\hline \multicolumn{5}{|c|}{ Other Sensors } \\
\hline & & $\begin{array}{l}\text { Current Reading } \\
\text { Last Good Reading } \\
\text { Quality Status }\end{array}$ & $\begin{array}{l}\text { Last Update Method } \\
\text { Test Processing }\end{array}$ & \\
\hline
\end{tabular}


HNF-3967, Rev. 5

\begin{tabular}{|c|c|c|c|c|}
\hline Step & Perform & \multicolumn{2}{|c|}{ Expected Result } & Initial \\
\hline & & $\begin{array}{l}\text { Units } \\
\text { High Alarm Limit } \\
\text { Low Alarm Limit } \\
\text { Deadband } \\
\text { Point Processing } \\
\text { ROC Processing } \\
\text { Station Status } \\
\text { Polling Freq. Index } \\
\text { Validity Interval } \\
\text { Expiration Time } \\
\text { Formula Expression } \\
\text { Formula Parameter }\end{array}$ & $\begin{array}{l}\text { Upper Instrument Limit } \\
\text { Lower Instrument Limit } \\
\text { Delta } \\
\text { Alarm Processing } \\
\text { Logging } \\
\text { Raw Value } \\
\text { Polling. Freq. Sec. }\end{array}$ & \\
\hline 3. & $\begin{array}{l}\text { Click the Update } \\
\text { button. } \\
\text { Wait for the } \\
\text { workspace to be } \\
\text { updated } \\
\text { (approximately } 5 \\
\text { seconds). }\end{array}$ & $\begin{array}{l}\text { Verify the following } \\
\text { - The date and tim } \\
\text { Good Reading A } \\
\text { - Reading displaye } \\
\text { - RPC is displayed } \\
\text { Method } \\
\text { Note: The readout lc } \\
\text { change to poll when } \\
\text { Note: An alarm coul } \\
\text { sensor is an alarm ro } \\
\text { Note: the current Rec } \\
\text { depending if the valu } \\
\text { Note: If sensor has } p \\
\text { RAW VALUE and th } \\
\text { updated. }\end{array}$ & $\begin{array}{l}\text { yed in the Readout Last } \\
\text { dated. } \\
\text { Current Reading is updated. } \\
\text { readout labeled Last Update } \\
\text { Last Update Method will } \\
\text { ll is taken. } \\
\text { zerated if the reading for the } \\
\text { ay or may not change } \\
\text { read has changed. } \\
\text { ocessing disabled then only the } \\
\text { RATION TIME will be }\end{array}$ & \\
\hline 4. & $\begin{array}{l}\text { Wait until the next } \\
\text { time the sensor is } \\
\text { polled. } \\
\text { Note: The } \\
\text { SACS_LEVEL } \\
\text { sensors are only } \\
\text { polled once a day } \\
\text { at approximately } \\
8: 00 P M\end{array}$ & $\begin{array}{l}\text { Verify the following } \\
\text { - The date and tim } \\
\text { Good Reading A } \\
\text { - Reading displaye } \\
\text { - POLL is displaye } \\
\text { Method } \\
\text { Note: An alarm coul } \\
\text { sensor is an alarm ro } \\
\text { Note: the current Re } \\
\text { depending if the valu } \\
\text { Note: The Readout L }\end{array}$ & $\begin{array}{l}\text { yed in the Readout Last } \\
\text { dated. } \\
\text { Current Reading is updated. } \\
\text { readout labeled Last Update } \\
\text { terated if the reading for the } \\
\text { tay or may not change } \\
\text { read has changed. } \\
\text { d Reading At will only be }\end{array}$ & \\
\hline
\end{tabular}


HNF-3967, Rev. 5

\begin{tabular}{|c|c|c|c|}
\hline Step & Perform & Expected Result & Initial \\
\hline & & $\begin{array}{l}\text { updated if the reading value changes by more than the } \\
\text { delta. }\end{array}$ & \\
\hline 5. & $\begin{array}{l}\text { Using the } \\
\text { emulator change } \\
\text { the value that is } \\
\text { read for the } \\
\text { sensor. } \\
\text { Press the Update } \\
\text { button. } \\
\text { Wait for the } \\
\text { workspace to be } \\
\text { updated } \\
\text { (approximately } 5 \\
\text { seconds). }\end{array}$ & $\begin{array}{l}\text { Verify the following: } \\
\text { - The date and time displayed in the Readout Last } \\
\text { Good Reading At is updated. } \\
\text { - Reading displayed in the Current Reading is updated } \\
\text { to the value issued by the emulator. } \\
\text { - RPC is displayed in the readout labeled Last Update } \\
\text { Method } \\
\text { Note: The readout labeled Last Update Method will } \\
\text { change to poll when next poll is taken. } \\
\text { Note: An alarm could be generated if the reading for the } \\
\text { sensor is an alarm range. }\end{array}$ & \\
\hline 6. & $\begin{array}{l}\text { Wait until the next } \\
\text { time the sensor is } \\
\text { polled. }\end{array}$ & $\begin{array}{l}\text { Verify the following: } \\
\text { - The date and time displayed in the Readout Last } \\
\text { Good Reading At is updated. } \\
\text { - Reading displayed in the Current Reading is updated. } \\
\text { - POLL is displayed in the readout labeled Last Update } \\
\text { Method } \\
\text { Note: The Readout Last Good Reading At will only be } \\
\text { updated if the reading value changes by more than the } \\
\text { delta. }\end{array}$ & \\
\hline 7. & $\begin{array}{l}\text { Click the TEST } \\
\text { button. }\end{array}$ & $\begin{array}{l}\text { Verify the following on the Sensor Details workspace: } \\
\text { - Quality Status is set to TEST (Note: Unless the status } \\
\text { is UNKNOWN) } \\
\text { - Testing Processing is set to true } \\
\text { Verify on the Current Alarms workspace that a blue } \\
\text { message is generated with the following information } \\
\text { - Date and Time when place in test mode } \\
\text { - Sensor Tag Name } \\
\text { Description - The TESTING PROCESS of [Tag } \\
\text { Name] has been ENABLED } \\
\text { Verify on the Control Panel that the Number of Sensors } \\
\text { Testing increase by } 1 \text {. }\end{array}$ & \\
\hline 8. & Click on the & Verify the Quality Status for the readings chosen sensor & \\
\hline
\end{tabular}


HNF-3967, Rev. 5

\begin{tabular}{|c|c|c|c|}
\hline Step & Perform & Expected Result & Initial \\
\hline & $\begin{array}{l}\text { Update button a } \\
\text { few times (more } \\
\text { than once) } \\
\text { Examine the } \\
\text { appropriate sensor } \\
\text { history file. } \\
\text { To examine the } \\
\text { file it may be } \\
\text { necessary to stop } \\
\text { G2 } 2^{\circledR} \text {. The } \\
\text { directory is } \\
\text { located at } \\
\text { f: } \text { BackedUp } \mid T M A \\
\text { CSDatalCurrent. }\end{array}$ & while in test mode is indicated as TEST. & \\
\hline 9. & $\begin{array}{l}\text { Click the TEST } \\
\text { button. }\end{array}$ & $\begin{array}{l}\text { Verify the following on the Sensor Details workspace: } \\
\text { - Quality Status is set to GOOD (Note: Unless the status } \\
\text { is UNKNOWN) } \\
\text { - Testing Processing is set to false } \\
\text { Verify on the Current Alarms workspace that a blue } \\
\text { message is generated with the following information } \\
\text { - Date and Time when place taken out of test mode } \\
\text { - Densor Tag Name } \\
\text { Description - The TESTING PROCESS of [Tag } \\
\text { Verify on the Control Panel that the Number of Sensors } \\
\text { Testing decreases by } 1 \text {. }\end{array}$ & \\
\hline 10. & $\begin{array}{l}\text { Click on the Print } \\
\text { button. }\end{array}$ & Verify the Sensor Details workspace is printed. & \\
\hline 11. & $\begin{array}{l}\text { Click on the Hide } \\
\text { button }\end{array}$ & Verify the Sensor Details workspace disappears. & \\
\hline
\end{tabular}

\subsubsection{Operation of Sensor History}

\begin{tabular}{|l|l|l|l|}
\hline Step & \multicolumn{1}{|c|}{ Perform } & Expected Result & Initial \\
\hline 1. & $\begin{array}{l}\text { Select a continuous sensor } \\
\text { at random that has history. }\end{array}$ & $\begin{array}{l}\text { Verify the trend chart is displayed and the tag } \\
\text { name is displayed above the trend chart }\end{array}$ & \\
\hline
\end{tabular}


HNF-3967, Rev. 5

\begin{tabular}{|c|c|c|c|}
\hline Step & Perform & Expected Result & Initial \\
\hline & $\begin{array}{l}\text { Display the individual } \\
\text { sensor trend chart for the } \\
\text { chosen sensor. }\end{array}$ & & \\
\hline 2. & Click on the trend chart. & $\begin{array}{l}\text { Verify the History Table is displayed with the } \\
\text { following: } \\
\text { - Hide }(X) \text { button } \\
\text { - Print }(P) \text { button } \\
\text { - Sensor tag name at top of workspace } \\
\text { - Table displaying the data (Point (PT), Value } \\
\text { and the Date/Time value was taken) for the } \\
\text { sensor over the displayed time period or } \\
1000 \text { points which ever comes first. } \\
\text { - High Button (High value for selected time } \\
\text { period) } \\
\text { - Low Button (Low value for selected time } \\
\text { period) } \\
\text { - Point (Used to go directly to a specific point) } \\
\text { - Topton of Table button }(\mid \triangleleft) \\
\text { - Previous page button }(\varangle) \\
\text { - Next page button }(\bullet) \\
\text { - End of table button }(\bullet \mid)\end{array}$ & \\
\hline 3. & Click on the High button & $\begin{array}{l}\text { Verify the position of the table displayed } \\
\text { contains the sensor point with the highest value. }\end{array}$ & \\
\hline 4. & Click on the Low button & $\begin{array}{l}\text { Verify the position of the table displayed } \\
\text { contains the sensor point with the lowest value. }\end{array}$ & \\
\hline 5. & $\begin{array}{l}\text { Chose a sensor point at } \\
\text { random. } \\
\text { Enter this point in the text } \\
\text { box associated with the } \\
\text { Point button. } \\
\text { Click on the Point button. }\end{array}$ & $\begin{array}{l}\text { Verify the position of the table displayed } \\
\text { contains the sensor point chosen. }\end{array}$ & \\
\hline 6. & $\begin{array}{l}\text { Click on the top of table } \\
\text { button }(\mid 4)\end{array}$ & $\begin{array}{l}\text { Verify that the portion of the table displayed is } \\
\text { the first page in the table. }\end{array}$ & \\
\hline 7. & $\begin{array}{l}\text { Click on the end of table } \\
\text { button }(\end{array}$ & $\begin{array}{l}\text { Verify the portion of the table displayed is the } \\
\text { last page in the table. }\end{array}$ & \\
\hline 8. & $\begin{array}{l}\text { Click the previous page } \\
\text { button }(4)\end{array}$ & $\begin{array}{l}\text { Verify the portion of the table displayed is the } \\
\text { previous page. }\end{array}$ & \\
\hline 9. & $\begin{array}{l}\text { Click the next page button } \\
\text { ( })\end{array}$ & $\begin{array}{l}\text { Verify the portion of the table displayed is the } \\
\text { next page. }\end{array}$ & \\
\hline 10. & Click on the Print button. & Verify the Sensor History workspace is printed. & \\
\hline
\end{tabular}


HNF-3967, Rev. 5

\begin{tabular}{|c|c|c|c|}
\hline Step & Perform & Expected Result & Initial \\
\hline 11. & Click on the table. & $\begin{array}{l}\text { Verify the history details workspace is displayed } \\
\text { with the following information: } \\
\text { - Hide (X) button } \\
\text { - Print (P) button } \\
\text { - Sensor Tag Name at top of workspace } \\
\text { - Total Point Count (signifies the total number } \\
\text { of points in history) } \\
\text { - Time Interval Point Count (signifies the } \\
\text { number of points display in history table and } \\
\text { trend chart for the selected time period) } \\
\text { - High Point Number } \\
\text { - High Value } \\
\text { - High Date/Time } \\
\text { - Low Point Number } \\
\text { - Low Value } \\
\text { - Select Time Interval } \\
\text { - } 1 \text { hour } \\
\text { - } 8 \text { hours } \\
\text { - } 24 \text { hours } \\
\text { - } 7 \text { days } \\
\text { - } 31 \text { days }\end{array}$ & \\
\hline 12. & $\begin{array}{l}\text { Select a time interval at } \\
\text { random. }\end{array}$ & $\begin{array}{l}\text { Verify the following workspaces are updated: } \\
\text { - Individual Sensor Trend Chart } \\
\text { - History Table } \\
\text { - History Details }\end{array}$ & \\
\hline 13. & Click on the Print button. & Verify the History Details workspace is printed. & \\
\hline 14. & $\begin{array}{l}\text { Click on the Hide button } \\
\text { for the Individual Sensor } \\
\text { Trend workspace. }\end{array}$ & $\begin{array}{l}\text { Verify the following workspaces disappear: } \\
\text { - Individual Sensor Trend Chart } \\
\text { - History Table } \\
\text { - History Details }\end{array}$ & \\
\hline
\end{tabular}

\subsubsection{Operation of User Selectable Trends}

This section describes the test cases for the individual selectable trends.

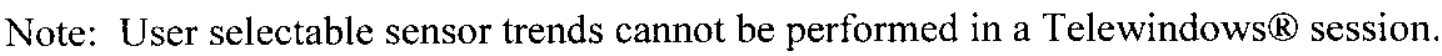

\begin{tabular}{|l|l|l|}
\hline Step & Perform & Expected Result
\end{tabular}


HNF-3967, Rev. 5

\begin{tabular}{|c|c|c|c|}
\hline Step & Perform & Expected Result & Initial \\
\hline 1. & $\begin{array}{l}\text { Click any enabled Tank } \\
\text { Icon in the Hanford Tank } \\
\text { Farm Facilities. (The icon } \\
\text { will not be gray.) } \\
\text { Click on a USER } \\
\text { SELECTABLE TRENDS } \\
\text { button. (located at the } \\
\text { bottom of the Tank Status } \\
\text { workspace.) }\end{array}$ & 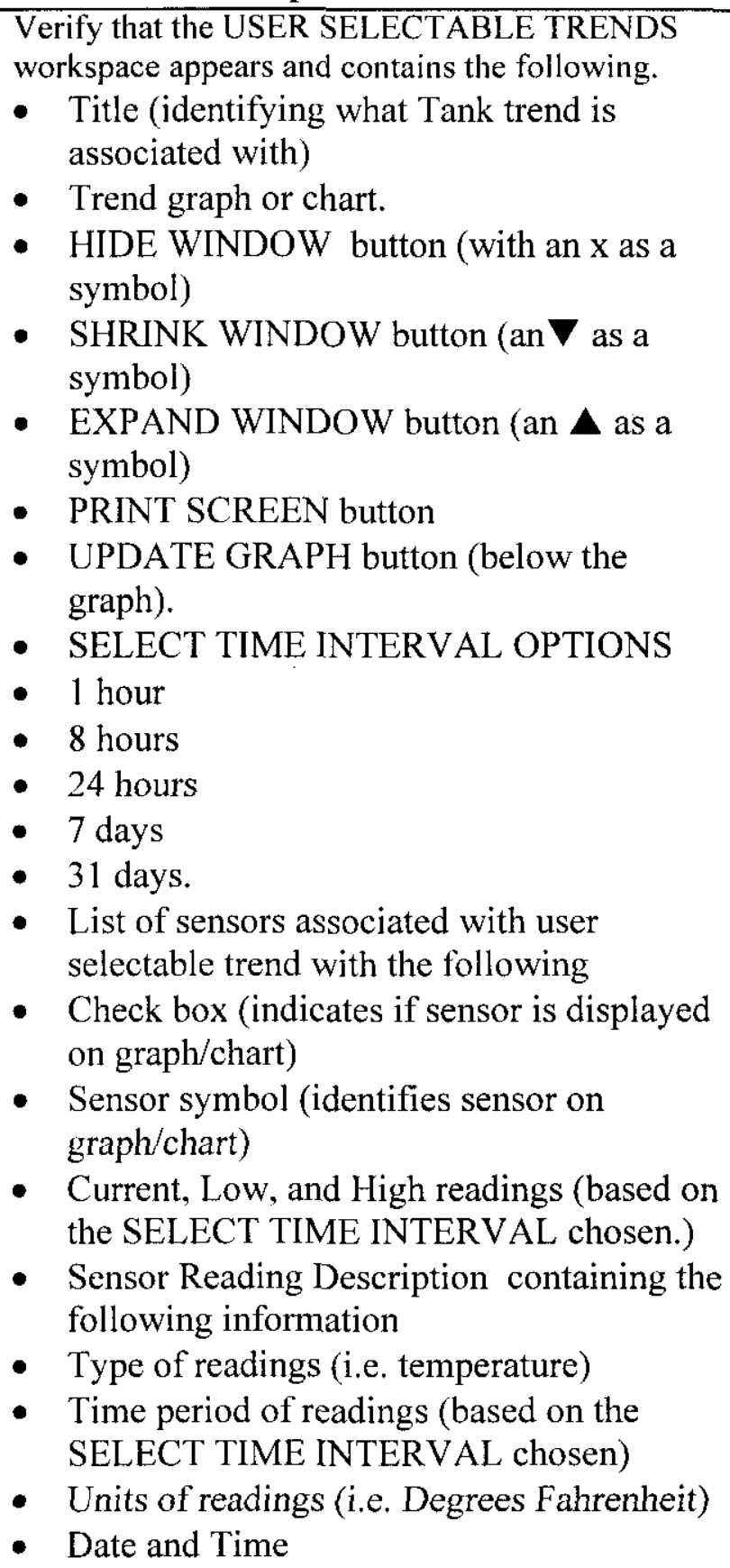 & \\
\hline 2. & $\begin{array}{l}\text { Click on the UPDATE } \\
\text { GRAPH button }\end{array}$ & $\begin{array}{l}\text { Verify the Graph/Chart has the following: } \\
\text { - The current value for each sensor on the } \\
\text { trend graph approximates the current value } \\
\text { on the digital display. } \\
\text { - The values line matches the symbol for } \\
\text { each sensor. } \\
\text { Trend graph label (below the } x \text {-axis of the } \\
\text { graph) reads: }\end{array}$ & \\
\hline
\end{tabular}




\begin{tabular}{|c|c|c|c|}
\hline Step & Perform & $\begin{array}{l}\text { Expected Result } \\
\text { "TANK xx-yyy SELECTED SENSORS } \\
\text { INDICATED BY X" } \\
\text { Where "xx-yyy" represents the name of the } \\
\text { tank. } \\
\text { - The time scale of the horizontal time axis is } \\
\text { based on the SELECT TIME INTERVAL } \\
\text { chosen. }\end{array}$ & Initial \\
\hline \multicolumn{4}{|c|}{ Operation of Sensor Check Box } \\
\hline 3. & $\begin{array}{l}\text { Click on the box of any } \\
\text { sensor that contains an } \mathrm{X} \text {. }\end{array}$ & Verify that the $\mathrm{X}$ is removed from the box. & \\
\hline 4. & $\begin{array}{l}\text { Click on the UPDATE } \\
\text { GRAPH button below the } \\
\text { graph. }\end{array}$ & $\begin{array}{l}\text { Verify the trend graph displays only lines for } \\
\text { the sensors that are checked. }\end{array}$ & \\
\hline 5. & $\begin{array}{l}\text { Click on the box of any } \\
\text { sensor that does not } \\
\text { contain an X. }\end{array}$ & Verify that the $\mathrm{X}$ is displayed in the box. & \\
\hline 6. & $\begin{array}{l}\text { Click on the UPDATE } \\
\text { GRAPH button below the } \\
\text { graph. }\end{array}$ & $\begin{array}{l}\text { Verify the trend graph displays only lines for } \\
\text { the sensors that are checked. }\end{array}$ & \\
\hline \multicolumn{4}{|c|}{$\begin{array}{l}\text { Operation of Sensor Time Interval Options } \\
\text { Note: } \text { May want to repeat using different time intervals }\end{array}$} \\
\hline 7. & $\begin{array}{l}\text { Click any "SELECT TIME } \\
\text { INTERVAL" option. }\end{array}$ & $\begin{array}{l}\text { Verify the following: } \\
\text { - A black dot appears in the circle of the time } \\
\text { interval selected. } \\
\text { - The Sensor Reading Description is } \\
\text { modified according to the SELECT TIME } \\
\text { INTERVAL chosen. (Note: Trend graph is } \\
\text { not updated automatically) }\end{array}$ & \\
\hline 8. & $\begin{array}{l}\text { Click on the UPDATE } \\
\text { GRAPH button below the } \\
\text { graph. }\end{array}$ & $\begin{array}{l}\text { Verify the horizontal time scale of the trend } \\
\text { graph is reset to the SELECT TIME } \\
\text { INTERVAL chosen. }\end{array}$ & \\
\hline \multicolumn{4}{|c|}{ Operation of Shrink Window button } \\
\hline 9. & $\begin{array}{l}\text { Click on the SHRINK } \\
\text { WINDOW button (an } \boldsymbol{\nabla} \text { as } \\
\text { a symbol). }\end{array}$ & Verify that the workspace shrinks. & \\
\hline 10. & $\begin{array}{l}\text { Drag the workspace to the } \\
\text { upper right hand corner. }\end{array}$ & $\begin{array}{l}\text { Verify that the workspace stops at the edge of } \\
\text { the screen when dragged to the top or to the } \\
\text { right. }\end{array}$ & \\
\hline \multicolumn{4}{|c|}{ Operation of Expand Window button } \\
\hline 11. & $\begin{array}{l}\text { Click on the EXPAND } \\
\text { WINDOW button (an } \\
\text { as a symbol). }\end{array}$ & Verify that the workspace enlarges. & \\
\hline
\end{tabular}


HNF-3967, Rev. 5

\begin{tabular}{|c|l|l|c|}
\hline Step & \multicolumn{1}{|c|}{ Perform } & \multicolumn{1}{c|}{ Expected Result } & Initial \\
\hline 12. & $\begin{array}{l}\text { Click on the PRINT } \\
\text { SCREEN button. }\end{array}$ & $\begin{array}{l}\text { Verify that the User Selectable Trend } \\
\text { workspace prints. }\end{array}$ & \multicolumn{1}{|c|}{ Operation of the HIDE button } \\
\hline \multicolumn{3}{|l|}{$\begin{array}{l}\text { Click on the HIDE } \\
\text { WINDOW. }\end{array}$} & \begin{tabular}{l} 
Verify that the workspace is hidden. \\
\hline 13.
\end{tabular}
\end{tabular}

\subsection{REPORTS}

\subsubsection{Reports}

Prior to performing this test case set up sensors so that they will appear in the selected report.

\begin{tabular}{|c|c|c|c|}
\hline Step & Perform & Expected Result & Initial \\
\hline 1. & $\begin{array}{l}\text { Select a Report button at } \\
\text { random from the Reports } \\
\text { Menu workspace. }\end{array}$ & Verify the chosen Report is displayed correctly. & \\
\hline 2. & $\begin{array}{l}\text { Click on the Title block of } \\
\text { the report table. }\end{array}$ & $\begin{array}{l}\text { Verify the help workspace for this report is } \\
\text { displayed. }\end{array}$ & \\
\hline 3. & $\begin{array}{l}\text { Click the Update button } \\
\text { Wait until Table } \\
\text { Processing Status displays } \\
\text { DONE. }\end{array}$ & $\begin{array}{l}\text { Verify the following: } \\
\text { - Report Table is updated } \\
\text { - Date of Report is updated. } \\
\text { Note the Table Processing Status will change } \\
\text { from Done to Active back to Done. }\end{array}$ & \\
\hline 4. & Click the Maximize button. & Verify the workspace is maximized. & \\
\hline 5. & Click the Minimize button & Verify the workspace is minimized & \\
\hline 6. & $\begin{array}{l}\text { Exercise the following } \\
\text { buttons: } \\
\text { Top of report }(\mid<) \\
\text { End of report }(\square \mid) \\
\text { Previous page ( }) \\
\text { Next page }(\square) \text {. }\end{array}$ & $\begin{array}{l}\text { Verify correct operation of each button. (Note: } \\
\text { Report may fit on one page and therefore no } \\
\text { change is seen.) }\end{array}$ & \\
\hline 7. & $\begin{array}{l}\text { Click the Update button } \\
\text { immediately followed by } \\
\text { the Abort Report button. } \\
\text { Note: This will only work if }\end{array}$ & $\begin{array}{l}\text { Verify the following: } \\
\text { - Date of Report is updated } \\
\text { - Table Processing Status changes to Abort }\end{array}$ & \\
\hline
\end{tabular}


HNF-3967, Rev. 5

\begin{tabular}{|c|c|c|c|}
\hline Step & Perform & Expected Result & Initial \\
\hline & $\begin{array}{l}\text { time to process the report } \\
\text { is long enough so that the } \\
\text { Abort button can be } \\
\text { selected. }\end{array}$ & $\begin{array}{l}\text { Note the Table Processing Status will change } \\
\text { from Done to Active to Abort }\end{array}$ & \\
\hline 8. & $\begin{array}{l}\text { Exercise any button (s) } \\
\text { specific to the report. }\end{array}$ & Verify correct operation of the button(s). & \\
\hline 9. & $\begin{array}{l}\text { Click on the Print button } \\
\text { (P). (Note: Not functional } \\
\text { on the remote stations at } \\
\text { this time.) }\end{array}$ & $\begin{array}{l}\text { Verify the portion of the workspace displayed is } \\
\text { printed to the printer. }\end{array}$ & \\
\hline 10. & $\begin{array}{l}\text { Click on the Hide button } \\
(\mathrm{X}) \text {. }\end{array}$ & Verify the report workspace is hidden. & \\
\hline
\end{tabular}

\subsection{EXTERNAL INTERFACES}

\subsubsection{Acromag ${ }^{\mathrm{TM}}$}

The tests in this section require the use of an Acromag ${ }^{\mathrm{TM}}$ emulator. The test should be run on the development machine.

\subsubsection{Conversion of Acromag ${ }^{\mathrm{TM}}$ Temperature Output to Engineering Units}

\begin{tabular}{|c|c|c|c|}
\hline Step & Perform & Expected Result & Initial \\
\hline 1. & $\begin{array}{l}\text { From the tag list, choose } \\
\text { an Acromag TM temperature } \\
\text { sensor at random. } \\
\text { Display the Sensor Details } \\
\text { for the chosen sensor. } \\
\text { Press the Update button } \\
\text { then use the Formula } \\
\text { expression and Raw Value } \\
\text { to calculate the current } \\
\text { reading for the sensor. }\end{array}$ & Write the value here & \\
\hline 2. & $\begin{array}{l}\text { Compare the Current } \\
\text { Reading with the reading } \\
\text { in Step } 1 .\end{array}$ & Verify that the readings are the same. & \\
\hline 3. & $\begin{array}{l}\text { Display the history details } \\
\text { for this sensor. }\end{array}$ & $\begin{array}{l}\text { Verify that the value is displayed and matches } \\
\text { the value recorded in Step } 1 \text {. (Note: It is } \\
\text { possible for the value to be displayed more than } \\
\text { once in the history details if it crosses a limit } \\
\text { boundary.) }\end{array}$ & \\
\hline
\end{tabular}


HNF-3967, Rev. 5

\subsubsection{Conversion of Acromag ${ }^{\mathrm{TM}} 4$ to $20 \mathrm{ma}$ Output to Engineering Units}

\begin{tabular}{|c|c|c|c|}
\hline Step & Perform & Expected Result & Initial \\
\hline 1. & $\begin{array}{l}\text { From the tag list, choose } \\
\text { an Acromag }{ }^{\mathrm{TM}} \text { non- } \\
\text { temperature sensor at } \\
\text { random, e.g., pressure, } \\
\text { flow, surface level, ... } \\
\text { Display the Sensor Details } \\
\text { for the chosen sensor. } \\
\text { Press the Update button } \\
\text { then use the Formula } \\
\text { expression and Raw Value } \\
\text { to calculate the current } \\
\text { reading for the sensor. }\end{array}$ & Write the value here & \\
\hline 2. & $\begin{array}{l}\text { Compare the Current } \\
\text { Reading with the reading } \\
\text { in Step } 1 .\end{array}$ & Verify that the readings are the same. & \\
\hline 3. & $\begin{array}{l}\text { Display the history details } \\
\text { for this sensor. }\end{array}$ & $\begin{array}{l}\text { Verify that the value is displayed and matches } \\
\text { the value recorded in Step } 1 \text {. (Note: It is } \\
\text { possible for the value to be displayed more than } \\
\text { once in the history details if it crosses a limit } \\
\text { boundary.) }\end{array}$ & \\
\hline
\end{tabular}

\subsubsection{Conversion of Acromag ${ }^{\mathrm{TM}}$ Digital Data to Discrete States}

The Acromag ${ }^{\mathrm{TM}}$ emulator does not directly support digital input for the Acromag ${ }^{\mathrm{TM}}$. A digital value of 0 may be simulated with a temperature value of $32.0 \mathrm{~F}$. A digital 1 is simulated with a temperature of $32.18 \mathrm{~F}$. Any other value will be an unknown state.

\begin{tabular}{|l|l|l|c|}
\hline Step & \multicolumn{1}{|c|}{ Perform } & \multicolumn{1}{c|}{ Expected Result } & Initial \\
\hline 1. & $\begin{array}{l}\text { Using the tag list, choose } \\
\text { an enabled Acromag } \\
\text { digital sensor at random. } \\
\text { Use the emulator to } \\
\text { simulate a value of digital } \\
0 \text { for this sensor. } \\
\text { Press the Update button }\end{array}$ & Verify that the sensor is in alarm. & \\
\hline
\end{tabular}


HNF-3967, Rev. 5

\begin{tabular}{|l|l|l|l|}
\hline Step & \multicolumn{1}{|c|}{ Perform } & \multicolumn{1}{c|}{ Expected Result } & Initial \\
\hline 2. & $\begin{array}{l}\text { Use the emulator to } \\
\text { simulate a value of digital } \\
1 \text { for this sensor. } \\
\text { Press the Update button }\end{array}$ & Verify that the sensor is reset. & \\
\hline
\end{tabular}

\subsection{2 $\quad$ Enraf $^{\circledR}$}

The tests in this section require the use of an Enraf ${ }^{\circledR}$ emulator. The test should be run on the development machine.

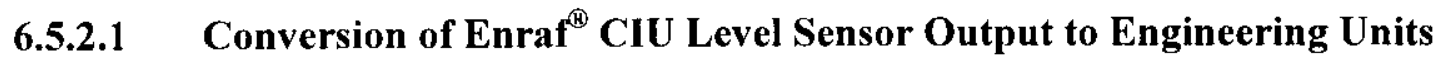

\begin{tabular}{|c|c|c|c|}
\hline Step & Perform & Expected Result & Initial \\
\hline 1. & $\begin{array}{l}\text { From the tag list, choose } \\
\text { an Enraf }{ }^{(B)} \text { CIU level sensor } \\
\text { at random. } \\
\text { Display the Sensor Details } \\
\text { for the chosen sensor. } \\
\text { Press the Update button } \\
\text { then use the Formula } \\
\text { expression and Raw Value } \\
\text { to calculate the current } \\
\text { reading for the sensor. }\end{array}$ & Write the value here & \\
\hline 2. & $\begin{array}{l}\text { Compare the Current } \\
\text { Reading with the reading } \\
\text { in Step } 1 .\end{array}$ & Verify that the readings are the same. & \\
\hline 3. & $\begin{array}{l}\text { Display the history details } \\
\text { for this sensor. }\end{array}$ & $\begin{array}{l}\text { Verify that the value is displayed and matches } \\
\text { the value recorded in Step } 1 \text {. (Note: It is } \\
\text { possible for the value to be displayed more than } \\
\text { once in the history details if it crosses a limit } \\
\text { boundary.) }\end{array}$ & \\
\hline
\end{tabular}


HNF-3967, Rev. 5

\subsubsection{Conversion of Enraf ${ }^{\circledR}$ CIU Pressure Sensor Output to Engineering Units}

\begin{tabular}{|l|l|l|l|}
\hline Step & \multicolumn{1}{|c|}{ Perform } & \multicolumn{1}{c|}{ Expected Result } & Initial \\
\hline 1. & $\begin{array}{l}\text { From the tag list, choose } \\
\text { an Enraf } \\
\text { sensor at random. }\end{array}$ & Write the value here \\
$\begin{array}{l}\text { Display the Sensor Details } \\
\text { for the chosen sensor. } \\
\text { Press the Update button } \\
\text { then use the Formula } \\
\text { expression and Raw Value } \\
\text { to calculate the current } \\
\text { reading for the sensor. }\end{array}$ & $\begin{array}{l}\text { Compare the Current } \\
\text { Reading with the reading } \\
\text { in Step 1. }\end{array}$ & $\begin{array}{l}\text { Verify that the readings are the same. } \\
\text { for this sensor. }\end{array}$ & \\
\hline 3. & $\begin{array}{l}\text { Display the history details } \\
\text { for the value recorded in Step 1. (Note: It is } \\
\text { Verify that the value is displayed and matches } \\
\text { possible for the value to be displayed more than } \\
\text { once in the history details if it crosses a limit } \\
\text { boundary.) }\end{array}$ & \\
\hline
\end{tabular}

\subsubsection{Conversion of Enraf ${ }^{\circledR}$ CIU Alarm Status to Discrete States}

\begin{tabular}{|l|l|l|l|}
\hline Step & \multicolumn{1}{|c|}{ Perform } & \multicolumn{1}{c|}{ Expected Result } & Initial \\
\hline 1. & $\begin{array}{l}\text { From the tag list, choose } \\
\text { an Enraf } \\
\text { sensor at random. }\end{array}$ & Verify that the sensor is in High alarm. \\
$\begin{array}{l}\text { Use the emulator to } \\
\text { simulate a High Alarm for } \\
\text { this sensor. } \\
\text { Press the Update button }\end{array}$ & $\begin{array}{l}\text { Use the emulator to } \\
\text { simulate a Normal for this } \\
\text { sensor. } \\
\text { Press the Update button }\end{array}$ & Verify that the sensor is in Reset (Normal). & \\
\hline 2. & & \\
\hline
\end{tabular}


HNF-3967, Rev. 5

\begin{tabular}{|l|l|l|c|}
\hline Step & \multicolumn{1}{|c|}{ Perform } & \multicolumn{1}{|c|}{ Expected Result } & Initial \\
\hline 3. & $\begin{array}{l}\text { Use the emulator to } \\
\text { simulate a Low Alarm for } \\
\text { this sensor. } \\
\text { Press the Update button }\end{array}$ & Verify that the sensor is in Low alarm. & \\
\hline 4. & $\begin{array}{l}\text { Use the emulator to } \\
\text { simulate a Normal for this } \\
\text { sensor. } \\
\text { Press the Update button }\end{array}$ & Verify that the sensor is in Reset (Normal). & \\
\hline
\end{tabular}

\subsubsection{Westronics ${ }^{\circledR}$}

The tests in this section require the use of a Westronics ${ }^{(1)}$ emulator. The test should be run on the development machine.

\subsubsection{Conversion of Westronics ${ }^{\circledR}$ Temperature Output to Engineering Units}

\begin{tabular}{|c|c|c|c|}
\hline Step & Perform & Expected Result & Initial \\
\hline 1. & $\begin{array}{l}\text { From the tag list, choose a } \\
\text { Westronics }{ }^{\otimes} \text { temperature } \\
\text { sensor at random. } \\
\text { Display the Sensor Details } \\
\text { for the chosen sensor. } \\
\text { Press the Update button } \\
\text { then use the Formula } \\
\text { expression and Raw Value } \\
\text { to calculate the current } \\
\text { reading for the sensor. }\end{array}$ & Write the value here & \\
\hline 2. & $\begin{array}{l}\text { Compare the Current } \\
\text { Reading with the reading } \\
\text { in Step } 1 .\end{array}$ & Verify that the readings are the same. & \\
\hline 3. & $\begin{array}{l}\text { Display the history details } \\
\text { for this sensor. }\end{array}$ & $\begin{array}{l}\text { Verify that the value is displayed and matches } \\
\text { the value recorded in Step } 1 \text {. (Note: It is } \\
\text { possible for the value to be displayed more than } \\
\text { once in the history details if it crosses a limit } \\
\text { boundary.) }\end{array}$ & \\
\hline
\end{tabular}

\subsubsection{Panalarm ${ }^{(1)}$}


The tests in this section require the use of a Panalarm ${ }^{(i)}$ emulator. The test should be run on the development machine.

\subsubsection{Conversion of Panalarm ${ }^{(1)}$ Output to Digital Data to Discrete States}

\begin{tabular}{|c|c|c|c|}
\hline Step & Perform & Expected Result & Initial \\
\hline 1. & $\begin{array}{l}\text { Using the tag list, choose a } \\
\text { Panalarm }{ }^{(\beta)} \text { sensor at } \\
\text { random. } \\
\text { Use the emulator to } \\
\text { simulate a value of digital } \\
1 \text { for this sensor. } \\
\text { After an appropriate delay } \\
\text { for the TMACS to poll the } \\
\text { emulator for this sensor. }\end{array}$ & Verify that the sensor is in alarm. & \\
\hline 2. & $\begin{array}{l}\text { Use the emulator to } \\
\text { simulate a value of digital } \\
0 \text { for this sensor. } \\
\text { After an appropriate delay } \\
\text { for the TMACS to poll the } \\
\text { emulator for this sensor. }\end{array}$ & Verify that the sensor is reset. & \\
\hline 3. & Return to the main screen. & & \\
\hline
\end{tabular}

\subsubsection{SACS}

TMACS retrieves surface level data from SACS whenever TMACS starts and at 2000 every evening thereafter. The "last SACS reading" will be the last reading taken and marked good (the quality status was set to "G") before TMACS retrieves that data.

\begin{tabular}{|c|c|c|c|}
\hline Step & Perform & Expected ResuIt & Initial \\
\hline 1. & $\begin{array}{l}\text { Select a surface-level } \\
\text { sensor has been configured } \\
\text { for polling from SACS. }\end{array}$ & $\begin{array}{l}\text { Record the sensor and tank names. } \\
\text { Sensor } \\
\text { Tank }\end{array}$ & \\
\hline 2. & $\begin{array}{l}\text { On the Hanford Tank Farm } \\
\text { Facilities workspace, click } \\
\text { on the tank icon for the } \\
\text { selected tank. } \\
\text { Click on the surface-level } \\
\text { icon. }\end{array}$ & $\begin{array}{l}\text { Verify that the Sensor Trend workspace } \\
\text { appears. }\end{array}$ & \\
\hline 3. & $\begin{array}{l}\text { Click on the detail button. } \\
\text { (Upper right-hand corner } \\
\text { of the Sensor Trend } \\
\text { workspace.) } \\
\text { Click on the Update (U) }\end{array}$ & $\begin{array}{l}\text { Verify that the details about the surface-level } \\
\text { sensor appear. } \\
\text { Record the: } \\
\text { Current Reading } \\
\text { Last Good Reading } \\
\text { Sensor Type Name }\end{array}$ & \\
\hline
\end{tabular}


HNF-3967, Rev. 5

\begin{tabular}{|c|c|c|c|}
\hline Step & Perform & Expected Result & Initial \\
\hline & button. & slvl_dttm & \\
\hline 4. & $\begin{array}{l}\text { Hide the Sensor Trend } \\
\text { workspace. }\end{array}$ & & \\
\hline 5. & $\begin{array}{l}\text { Obtain the last SACS } \\
\text { database reading for the } \\
\text { selected tank. (Note: This } \\
\text { will be on the UDO server } \\
\text { most likely.) This may be } \\
\text { obtained from the system } \\
\text { administrator using the } \\
\text { following code: } \\
\text { lp_LastSLVLReading } \\
\text { '[Tank Name]' } \\
\text { select * } \\
\text { from } \\
\text { TMACS_LASTSLVLREA } \\
\text { DING }\end{array}$ & $\begin{array}{l}\text { Verify that the values obtained in this step } \\
\text { match the values recorded in Step } 3 \text {. }\end{array}$ & \\
\hline
\end{tabular}

\subsection{POINT PROCESSING}

\subsubsection{Continuous Sensor (Non Rate of Change) Automated Functional Test}

This procedure automatically tests the state changes for a continuous sensor.

\begin{tabular}{|c|c|c|c|}
\hline Step & Perform & $\begin{array}{l}\text { Expected Result } \\
\end{array}$ & Initial \\
\hline 1. & $\begin{array}{l}\text { On the POINT } \\
\text { PROCESSING } \\
\text { FUNCTIONAL TEST } \\
\text { workspace click on the } \\
\text { Point Processing for } \\
\text { Continuous Point - All } \\
\text { Function excepts Rate of } \\
\text { Change button }\end{array}$ & $\begin{array}{l}\text { Verify the CONTINUOUS FUNCTIONAL } \\
\text { TEST (Except ROC) workspace appears. }\end{array}$ & \\
\hline 2. & $\begin{array}{l}\text { On the CONTINUOUS } \\
\text { FUNCTIONAL TEST } \\
\text { (Except ROC) workspace: } \\
\text { - Set the Step Mode to } \\
\text { "Off." } \\
\text { - Set Print Results to } \\
\text { "Last" } \\
\text { Activate the "Run Point }\end{array}$ & Verify that the process continues to completion & \\
\hline
\end{tabular}


HNF-3967, Rev. 5

\begin{tabular}{|l|l|l|l|}
\hline Step & \multicolumn{1}{|c|}{ Perform } & \multicolumn{1}{|c|}{ Expected Result } & Initial \\
\hline & Processing" button. & & \\
\hline 3. & Examine the results & Verify no errors are reported. & \\
\hline 4. & Print the final workspace. & Keep printout for project files. & \\
\hline
\end{tabular}

\subsubsection{Continuous Sensor (Rate of Change) Automated Functional Test}

\begin{tabular}{|l|l|l|l|}
\hline Step & \multicolumn{1}{|c|}{ Perform } & \multicolumn{1}{|c|}{ Expected Result } & Initial \\
\hline 1. & $\begin{array}{l}\text { On the POINT } \\
\text { PROCESSING } \\
\text { FUNCTIONAL TEST } \\
\text { workspace click on the } \\
\text { Point Processing for } \\
\text { Continuous Point -Rate } \\
\text { of Change button. }\end{array}$ & $\begin{array}{l}\text { Verify the CONTINUOUS FUNCTIONAL } \\
\text { TEST (With ROC) workspace appears. }\end{array}$ & \\
\hline 2. & $\begin{array}{l}\text { On the ROC } \\
\text { FUNCTIONAL TEST } \\
\text { workspace: } \\
\text { Set the Step Mode to } \\
\text { "Off." } \\
\text { Set Print Results to "Last" } \\
\text { Activate the "Run Point } \\
\text { Processing" button. }\end{array}$ & Verify that the process continues to completion. & \\
\hline 3. & Examine the workspace. & Verify no errors are reported. & \\
\hline 4. & Print the final workspace. & Keep printout for project files. & \\
\hline
\end{tabular}

\subsubsection{Discrete Sensor Automated Functional Test}

This procedure automatically tests the state changes of a discrete sensor.

\begin{tabular}{|l|l|l|l|}
\hline Step & \multicolumn{1}{|c|}{ Perform } & \multicolumn{1}{|c|}{ Expected Result } & Initial \\
\hline 1. & $\begin{array}{l}\text { On the POINT } \\
\text { PROCESSING } \\
\text { FUNCTIONAL TEST } \\
\text { workspace click on the } \\
\text { Point Processing for } \\
\text { Discrete Points - All } \\
\text { Functions button }\end{array}$ & $\begin{array}{l}\text { Verify the DISCRETE FUNCTIONAL TEST } \\
\text { workspace appears. }\end{array}$ & \\
\hline 2. & $\begin{array}{l}\text { On the Discrete Functional } \\
\text { Test workspace: } \\
\text { Set the Step Mode to } \\
\text { "Off." } \\
\text { Set Print Results to "Last" } \\
\text { Activate the "Run Point } \\
\text { Processing " button. }\end{array}$ & & \\
\hline
\end{tabular}


HNF-3967, Rev. 5

\begin{tabular}{|l|l|l|c|}
\hline Step & \multicolumn{1}{|c|}{ Perform } & \multicolumn{1}{|c|}{ Expected Result } & Initial \\
\hline 3. & Examine the workspace. & Verify no errors are reported. & \\
\hline 4. & Print the final workspace. & Keep printout for project files. & \\
\hline
\end{tabular}

\subsubsection{Operation of MOST RECENT ALARM and CURRENT ALARMS}

Prior to running this test the administrator should do the following:

1. Acknowledge all alarms so Current Alarm count goes to zero. Note: if this is not done, then note the number of current alarms.

2. Verify the following workspaces are visible:

- DISCRETE FUNCTIONAL TEST

- MOST RECENT ALARM

- control-PANEL

- CURRENT ALARM

\begin{tabular}{|c|c|c|c|}
\hline Step & Perform & $\begin{array}{r}\text { Expected Result } \\
\end{array}$ & Initial \\
\hline 1. & $\begin{array}{l}\text { On the Discrete Functional } \\
\text { Test Workspace } \\
\text { Set the Step Mode in ON. } \\
\text { Activate the RUN POINT } \\
\text { PROCESSING button. } \\
\text { Examine the Current } \\
\text { Alarm box. }\end{array}$ & Note the number of current alarms & \\
\hline 2. & $\begin{array}{l}\text { Enter } 4 \text { in Dip-switch type- } \\
\text { in box on the Discrete } \\
\text { Functional Test } \\
\text { Workspace. }\end{array}$ & $\begin{array}{l}\text { Verify the following: } \\
\text { - A white message for the discrete alarm is } \\
\text { generated in the MOST RECENT ALARM } \\
\text { workspace. } \\
\text { - Sensor Icon Blinking = false } \\
\text { - Tank Icon Blinking = false } \\
\text { - No Current Alarms = } 1 \text { more than Step } 1 \text { on } \\
\text { the following workspaces: } \\
\text { 1. CURRENT ALARMS } \\
\text { 2. CONTROL PANEL. } \\
\text { 3. MOST RECENT ALARM }\end{array}$ & \\
\hline 3. & $\begin{array}{l}\text { Enter }-1 \text { in Dip-switch } \\
\text { type-in box on the } \\
\text { Discrete Functional Test } \\
\text { Workspace. }\end{array}$ & $\begin{array}{l}\text { Verify the following: } \\
\text { - Sensor Icon Blinking = false } \\
\text { - Tank Icon Blinking = false } \\
\text { - No Current Alarms }=1 \text { more than Step } 1 \text { on } \\
\text { the following workspaces: } \\
\text { 1. CURRENT ALARMS } \\
\text { 2. CONTROL PANEL } \\
\text { 3. MOST RECENT ALARM }\end{array}$ & \\
\hline
\end{tabular}


HNF-3967, Rev. 5

\begin{tabular}{|c|c|c|c|}
\hline Step & Perform & Expected Result & Initial \\
\hline 4. & $\begin{array}{l}\text { Enter } 2 \text { in Dip-switch type- } \\
\text { in box on the Discrete } \\
\text { Functional Test } \\
\text { Workspace. }\end{array}$ & $\begin{array}{l}\text { Verify the following: } \\
\text { - A discrete alarm message is generated in } \\
\text { the MOST RECENT ALARM workspace. } \\
\text { - Sensor Icon Blinking = true } \\
\text { - Tank Icon Blinking }=\text { true } \\
\text { No. Current Alarms }=2 \text { more than in Step } 1 \\
\text { on the following workspaces: } \\
\text { 1. CURRENT ALARMS } \\
\text { 2. CONTROL PANEL } \\
\text { 3. MOST RECENT ALARM }\end{array}$ & \\
\hline 5. & $\begin{array}{l}\text { On the Most Recent Alarm } \\
\text { workspace activate the } \\
\text { GOTO button }\end{array}$ & $\begin{array}{l}\text { Verify the following: } \\
\text { - TANK TEST-201 STATUS workspace is } \\
\text { brought to the top of the screen. } \\
\text { - The sensor is in alarm. }\end{array}$ & \\
\hline 6. & $\begin{array}{l}\text { Enter } \underline{0} \text { in Dip-switch type- } \\
\text { in box on the Discrete } \\
\text { Functional Test } \\
\text { Workspace. }\end{array}$ & $\begin{array}{l}\text { Verify the following: } \\
\text { - Discrete alarm message is reset. } \\
\text { - No. Current Alarms }=2 \text { more than Step } 1 \\
\text { on the following workspaces: } \\
\text { 1. CURRENT ALARMS } \\
\text { 2. CONTROL PANEL } \\
\text { 3. MOST RECENT ALARM }\end{array}$ & \\
\hline 7. & $\begin{array}{l}\text { Acknowledge alarm } \\
\text { message in MOST } \\
\text { RECENT ALARM } \\
\text { Window by clicking on it. }\end{array}$ & $\begin{array}{l}\text { Verify the following: } \\
\text { - Alarm Message disappears. } \\
\text { - Sensor Icon Blinking = false } \\
\text { - Tank Icon Blinking = false } \\
\text { - No. Current Alarms = } 1 \text { more than Step } 1 \\
\text { on the following workspaces: } \\
\text { 1. CURRENT ALARMS } \\
\text { 2. CONTROL PANEL } \\
\text { 3. MOST RECENT ALARM }\end{array}$ & \\
\hline 8. & $\begin{array}{l}\text { Acknowledge the White } \\
\text { alarm message }\end{array}$ & $\begin{array}{l}\text { Verify the following: } \\
\text { - Alarm Message disappears } \\
\text { - Sensor Icon Blinking = false } \\
\text { - Tank Icon Blinking = false } \\
\text { - No. Current Alarms = the same as in Step } 1 \\
\text { on the following workspaces: } \\
\text { 1. CURRENT ALARMS } \\
\text { 2. CONTROL PANEL } \\
\text { 3. MOST RECENT ALARM }\end{array}$ & \\
\hline
\end{tabular}

\subsubsection{Operation of Sensor Delta Band and Alarm Deadband}


HNF-3967, Rev. 5

This test will verify that the operation of the sensor band and the alarm deadband for continuous sensors.

Prior to running this test the administrator should do the following:

1. Verify that the Rate of Change processing is disabled for Sensor Continuous-200001.

2. Verify that the parameters for Sensor Continuous-200001 are set to match the parameters in Table 1. (See Prerequisites)

3. Verify that the following workspaces are visible.

- CONTINUOUS FUNCTIONAL TEST

- MOST RECENT ALARM

\begin{tabular}{|c|c|c|c|}
\hline Step & $\begin{array}{c}\text { Action } \\
\end{array}$ & Verify the Alarm Condition is: & Initial \\
\hline 1. & $\begin{array}{l}\text { On the Continuous Functional Test } \\
\text { Workspace } \\
\text { - Set the Step Mode in ON. } \\
\text { - Activate the RUN POINT } \\
\text { PROCESSING button. } \\
\text { - Enter } \mathbf{1 4 . 8} \text { in milli-amps type-in } \\
\text { box }\end{array}$ & NORMAL & \\
\hline 2. & Enter 14.4 in milli-amps type-in box & NORMAL & \\
\hline 3. & Enter 14.3 in milli-amps type-in box & NORMAL & \\
\hline 4. & Enter 14.8 in milli-amps type-in box & NORMAL & \\
\hline 5. & Enter 15.2 in milli-amps type-in box & ALARM-HIGH & \\
\hline 6. & Enter 15.3 in milli-amps type-in box & ALARM-HIGH & \\
\hline 7. & Enter 14.9 in milli-amps type-in box & ALARM-HIGH & \\
\hline 8. & Enter 14.6 in milli-amps type-in box & ALARM-HIGH & \\
\hline 9. & Enter 14.0 in milli-amps type-in box & NORMAL & \\
\hline 10. & Enter $\mathbf{1 3 . 5}$ in milli-amps type-in box & NORMAL & \\
\hline 11. & Enter 15.0 in milli-amps type-in box & ALARM-HIGH & \\
\hline 12. & Enter 10.6 in milli-amps type-in box & NORMAL & \\
\hline 13. & Enter $\mathbf{1 5 . 0}$ in milli-amps type-in box & ALARM-HIGH & \\
\hline 14. & Enter 9.9 in milli-amps type-in box & ALARM-LOW & \\
\hline 15. & Enter $\mathbf{1 0 . 2}$ in milli-amps type-in box & ALARM-LOW & \\
\hline 16. & Enter 10.5 in milli-amps type-in box & ALARM-LOW & \\
\hline 17. & Enter 11.0 in milli-amps type-in box & NORMAL & \\
\hline 18. & Enter 11.5 in milli-amps type-in box & NORMAL & \\
\hline
\end{tabular}

\subsubsection{Operation of Enable/Disable Procedures}

Verify that the following workspaces are visible. 
- Continuous Function Test

- Tank Test-201

- Enable/Disable Point Processing

- Most Recent Alarm

- Discrete-200001 Sensor

\begin{tabular}{|c|c|c|c|}
\hline Step & Perform & Expected Result & Initial \\
\hline 1. & $\begin{array}{l}\text { On the Continuous } \\
\text { Functional Test } \\
\text { workspace enter } 17 \text { in the } \\
\text { "milliamps" type-in box. }\end{array}$ & $\begin{array}{l}\text { Verify the following: } \\
\text { - Alarm message is displayed } \\
\text { - Number of Current Alarms increases by } \\
\text { one. }\end{array}$ & \\
\hline 2. & $\begin{array}{l}\text { Position the enable/disable } \\
\text { pointer over the } \\
\text { Continuous-200001 sensor } \\
\text { and activate the button } \\
\text { "Toggle Point". }\end{array}$ & $\begin{array}{l}\text { Verify that the following conditions occur: } \\
\text { - Blue message is displayed: "The POINT- } \\
\text { PROCESSING of CONTINUOUS-200001 } \\
\text { has been DISABLED", with the timestamp } \\
\text { of this change. } \\
\text { - Previous alarm message disappears and the } \\
\text { total "Number of Current Alarms" remains } \\
\text { the same. } \\
\text { - Point processing attribute of sensor changes } \\
\text { to false. } \\
\text { - Sensor turns gray. } \\
\text { - Tank color is the same as the DISCRETE- } \\
200001 \text { sensor color. }\end{array}$ & \\
\hline 3. & $\begin{array}{l}\text { With the enable/disable } \\
\text { pointer still over the } \\
\text { Continuous-200001 sensor, } \\
\text { activate the button "Toggle } \\
\text { Point". }\end{array}$ & $\begin{array}{l}\text { Verify that the following conditions occur: } \\
\text { - Blue message is displayed: "The POINT- } \\
\text { PROCESSING of CONTINUOUS-200001 } \\
\text { has been ENABLED", with the timestamp } \\
\text { of this change. } \\
\text { - "Number of Current Alarms" remains the } \\
\text { same. } \\
\text { - Point processing attribute of sensor changes } \\
\text { to true. } \\
\text { - Sensor turns white. } \\
\text { - Tank color will be based on the alarm } \\
\text { precedence of the sensors associated with } \\
\text { the tank. }\end{array}$ & \\
\hline 4. & $\begin{array}{l}\text { Select a tank on the HTFF } \\
\text { workspace that has a good } \\
\text { mix of sensor types. } \\
\text { Enter the chosen tank in } \\
\text { the type-in box labeled } \\
\text { "Tank on which to enable / } \\
\text { disable point processing". }\end{array}$ & $\begin{array}{l}\text { Verify that the following conditions occur: } \\
\text { - Blue message is displayed: "The POINT- } \\
\text { PROCESSING of [the nearest sensor to the } \\
\text { pointer-frequently the level sensor] has } \\
\text { been DISABLED", with the timestamp of } \\
\text { this change; } \\
\text { - Point processing attribute of sensor changes } \\
\text { to false; }\end{array}$ & \\
\hline
\end{tabular}


HNF-3967, Rev. 5

\begin{tabular}{|c|c|c|c|}
\hline Step & Perform & Expected Result & Initial \\
\hline & $\begin{array}{l}\text { Without moving the } \\
\text { enable/disable pointer } \\
\text { activate the button "Toggle } \\
\text { Point". }\end{array}$ & $\begin{array}{l}\text { - Sensor turns gray; } \\
\text { - Tank color is the same as the highest } \\
\text { priority sensor alarm }\end{array}$ & \\
\hline 5. & $\begin{array}{l}\text { Activate the button } \\
\text { "Toggle Point" again. }\end{array}$ & $\begin{array}{l}\text { Verify that the following conditions occur: } \\
\text { - Blue message is displayed: "The POINT- } \\
\text { PROCESSING of [the nearest sensor to the } \\
\text { pointer] has been ENABLED", with the } \\
\text { timestamp of this change; } \\
\text { - Point processing attribute of sensor changes } \\
\text { to true; } \\
\text { - Sensor turns white; } \\
\text { - Tank icon turns white or the color of the } \\
\text { highest priority sensor alarm. }\end{array}$ & \\
\hline 6. & $\begin{array}{l}\text { Activate the button "All } \\
\text { points in tank off". }\end{array}$ & $\begin{array}{l}\text { Verify that the following conditions occur: } \\
\text { - Blue messages are displayed: "The POINT- } \\
\text { PROCESSING of [each sensor monitoring } \\
\text { this tank] has been DISABLED" with the } \\
\text { time of this change; } \\
\text { - Point processing attribute of sensors } \\
\text { changes to false; } \\
\text { - Sensors turn gray; } \\
\text { - All sensor alarms associated with this tank } \\
\text { - Tank cleared; }\end{array}$ & \\
\hline 7. & $\begin{array}{l}\text { Activate the button "All } \\
\text { points in tank on". }\end{array}$ & $\begin{array}{l}\text { Verify that the following conditions occur: } \\
\text { - Blue messages are displayed: "The POINT- } \\
\text { PROCESSING of [each sensor monitoring } \\
\text { this tank] has been ENABLED" with the } \\
\text { time of this change; } \\
\text { - Point processing attribute of sensors } \\
\text { changes to true; } \\
\text { - Sensors turn white; } \\
\text { - Tank turns the appropriate color. }\end{array}$ & \\
\hline 8. & $\begin{array}{l}\text { On the Current Alarms } \\
\text { workspace click on the } \\
\text { Clear All Blue Messages } \\
\text { button. }\end{array}$ & $\begin{array}{l}\text { Verify the Blue Messages disappear from the } \\
\text { Current Alarms list. }\end{array}$ & \\
\hline 9. & $\begin{array}{l}\text { Hide the following } \\
\text { workspaces: } \\
\text { - Tank (selected in test) }\end{array}$ & Verify the workspaces are hidden. & \\
\hline
\end{tabular}




\begin{tabular}{|c|l|l|l|}
\hline Step & \multicolumn{1}{|c|}{ Perform } & \multicolumn{1}{|c|}{ Expected Result } & Initial \\
\hline & $\bullet \begin{array}{l}\text { Enable/Disable Point } \\
\text { Processing } \\
\text { Discrete-200001 } \\
\text { Sensor }\end{array}$ & & \\
\hline
\end{tabular}

\subsubsection{Miscellaneous Alarm Tests}

The purpose of this test is to verify the relationships between the sensor icons, tank icon, Current Alarms Workspace and the annuciator.

Prior to running this test the administrator should do the following:

1. Make sure the following workspaces visible.

- Functional Test Selection Workspace (Only to see the TANK-ICON-TEST-201 icon)

- Continuous Functional Test Workspace. Also perform following:

1. Set Step Mode On

2. Activate the Run Point Processing button

- Discrete Functional Test Workspace. Also perform following:

1. Set Step Mode On

2. Activate the Run Point Processing button

- TANK TEST-201 workspace.

- MOST RECENT ALARM workspace

- Discrete-200001 Sensor

2. Make sure the enunciator is enabled. This is done by the following:

- $\quad$ Bring up the TMACS-LIB workspace and its subworkspace labeled STARTUP-WS and Activate the "TOGGLE-AUDIBLE" button and verify that the display of the alarm-audible symbol changes from false to true.

\begin{tabular}{|c|c|c|c|}
\hline Step & Perform & $\begin{array}{r}\text { Expected Result } \\
\end{array}$ & Initial \\
\hline \multirow[t]{3}{*}{1.} & $\begin{array}{l}\text { Enter } 1 \text { in Dip-switch type-in box } \\
\text { on the Discrete Functional Test }\end{array}$ & $\begin{array}{l}\text { Beep } \\
\text { Beep = true }\end{array}$ & \\
\hline & $\begin{array}{l}\text { Enter a } 11 \text { in Milli-amp type-in } \\
\text { box on the Continuous } \\
\text { Functional Test Workspace } \\
\text { Note: May have to click on the }\end{array}$ & $\begin{array}{l}\text { Most Recent Alarm } \\
\begin{array}{l}\text { - } \\
\text { - }\end{array} \text { Dessage Status = Closing } \\
\text { - } \quad \text { Text Color }=\text { Red }\end{array}$ & \\
\hline & $\begin{array}{l}\text { the Discrete and Continuous } \\
\text { Function Test Workspaces. }\end{array}$ & Discrete Functional Test Workspace & \\
\hline
\end{tabular}


HNF-3967, Rev. 5

\begin{tabular}{|c|c|c|c|}
\hline Step & Perform & Expected Result & Initial \\
\hline & & 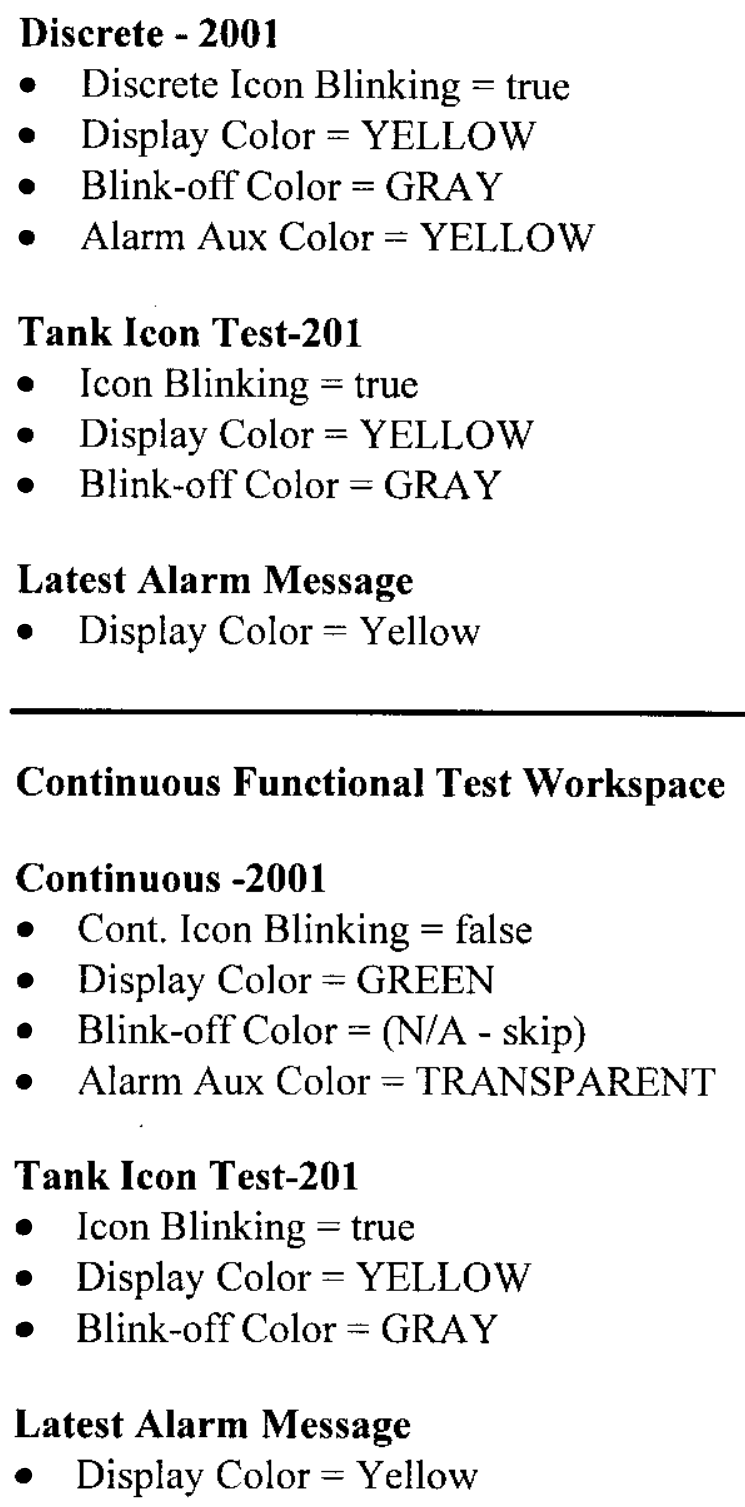 & \\
\hline 2. & $\begin{array}{l}\text { Activate ACK ALARMS Button } \\
\text { on Tank Test } 201 \text { status }\end{array}$ & $\begin{array}{l}\text { Beep } \\
\text { Beep = false } \\
\text { Most Recent Alarm } \\
\text { - Message Status = Acknowledged } \\
\text { - Display Color = Yellow } \\
\text { - Text Color = Black } \\
\text { Discrete Functional Test Workspace }\end{array}$ & \\
\hline
\end{tabular}


HNF-3967, Rev. 5

\begin{tabular}{|c|c|c|c|}
\hline Step & Perform & $\begin{array}{c}\text { Expected Result } \\
\end{array}$ & Initial \\
\hline & & 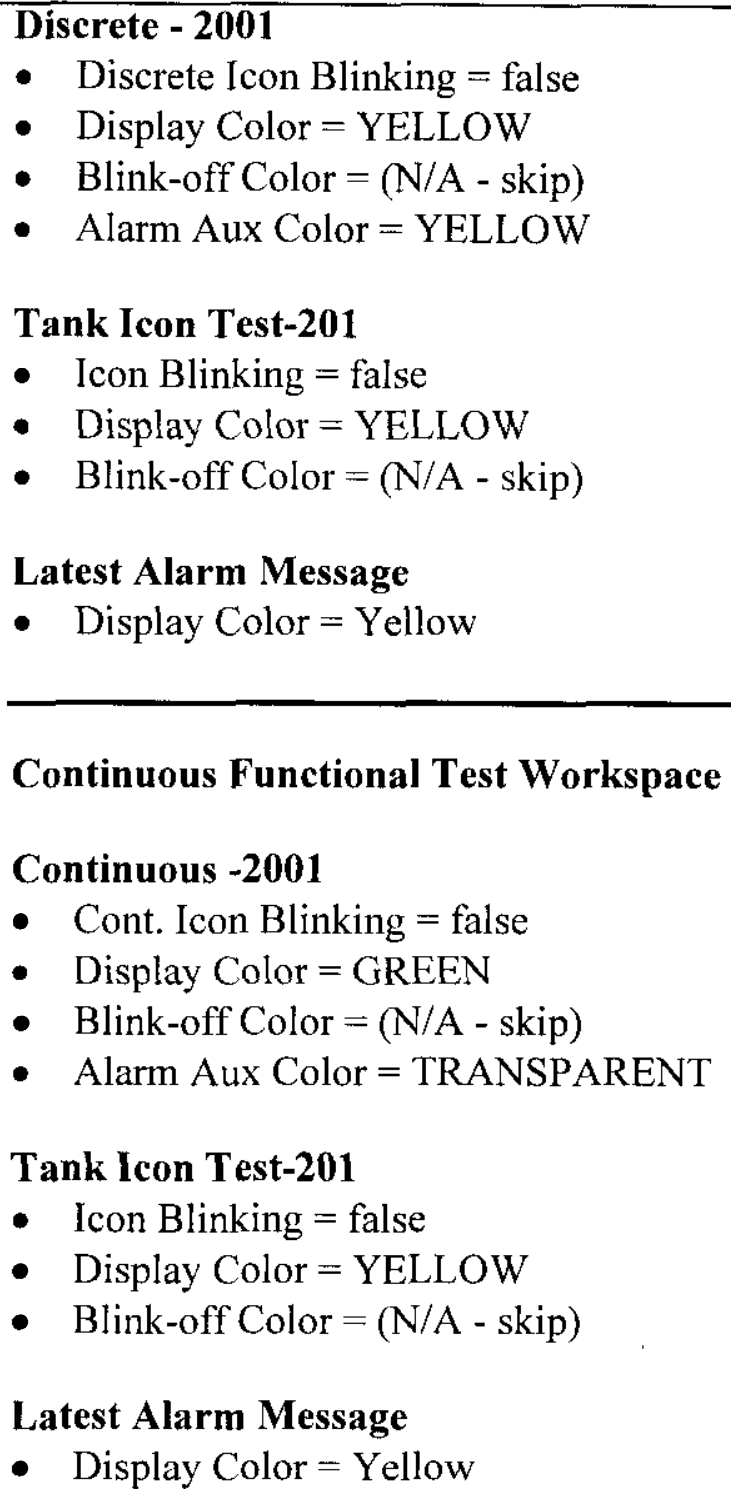 & \\
\hline 3 . & $\begin{array}{l}\text { Enter } 0 \text { in Dip-switch type-in box } \\
\text { on the Discrete Functional Test } \\
\text { Workspace. }\end{array}$ & 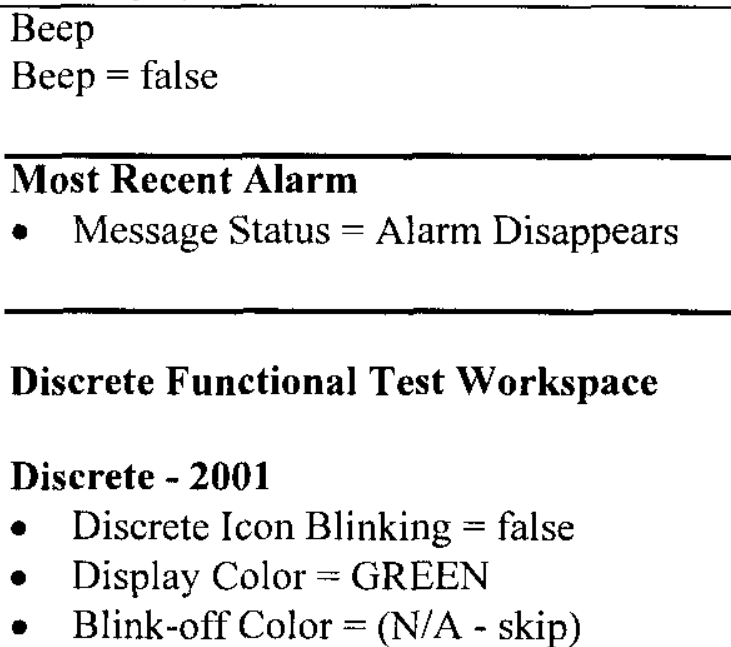 & \\
\hline
\end{tabular}


HNF-3967, Rev. 5

\begin{tabular}{|c|c|c|c|}
\hline Step & Perform & Expected Result & Initial \\
\hline & . & 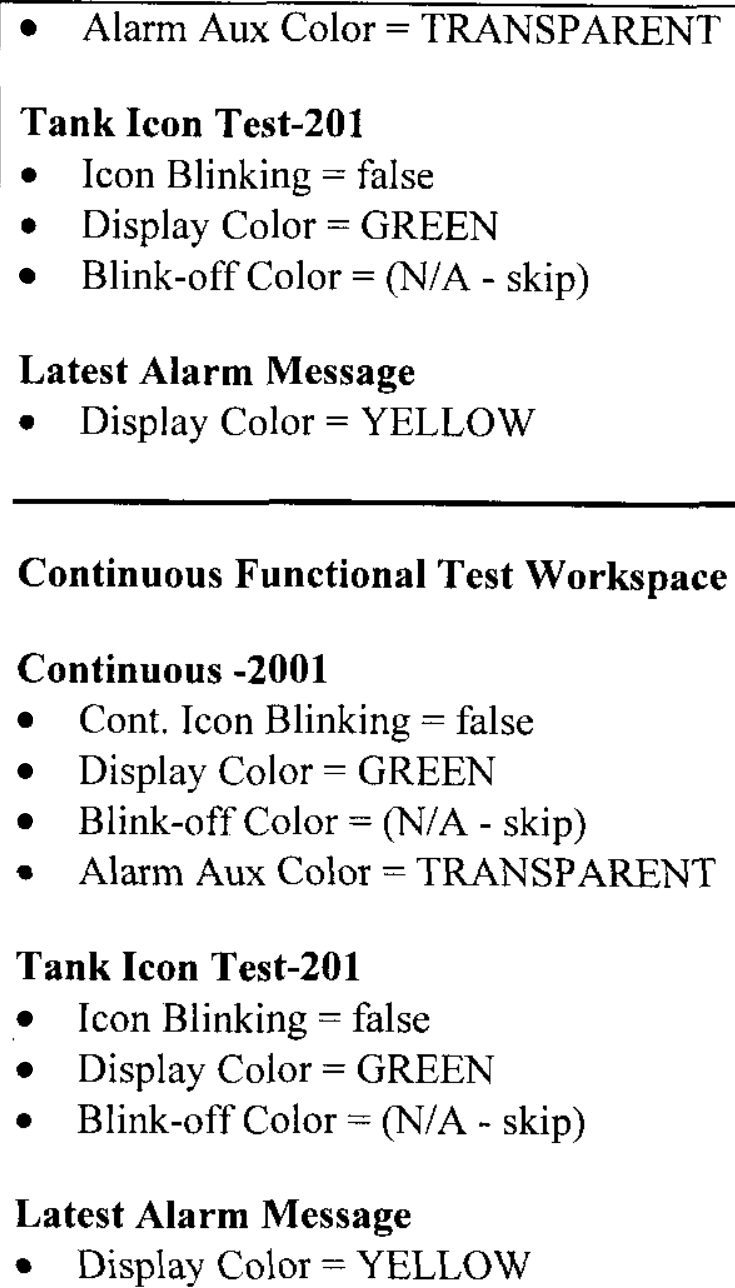 & \\
\hline 4. & $\begin{array}{l}\text { Enter a } 17 \text { in Milli-amp type-in } \\
\text { box on the Continuous } \\
\text { Functional Test Workspace }\end{array}$ & $\begin{array}{l}\text { Beep } \\
\text { Beep = true } \\
\text { Most Recent Alarm } \\
\text { - } \quad \text { Message Status = ALARM HIGH } \\
\text { - } \quad \text { Display Color = RED } \\
\text { - } \quad \text { Text Color = YELLOW } \\
\text { Discrete Functional Test Workspace } \\
\text { Discrete - 2001 } \\
\text { - } \quad \text { Discrete Icon Blinking = false } \\
\text { - Display Color = GREEN } \\
\text { - } \quad \text { Blink-off Color = (N/A - skip) } \\
\text { - } \quad \text { Alarm Aux Color = TRANSPARENT }\end{array}$ & \\
\hline
\end{tabular}


HNF-3967, Rev. 5

\begin{tabular}{|c|c|c|c|}
\hline Step & Perform & Expected Result & Initial \\
\hline & & 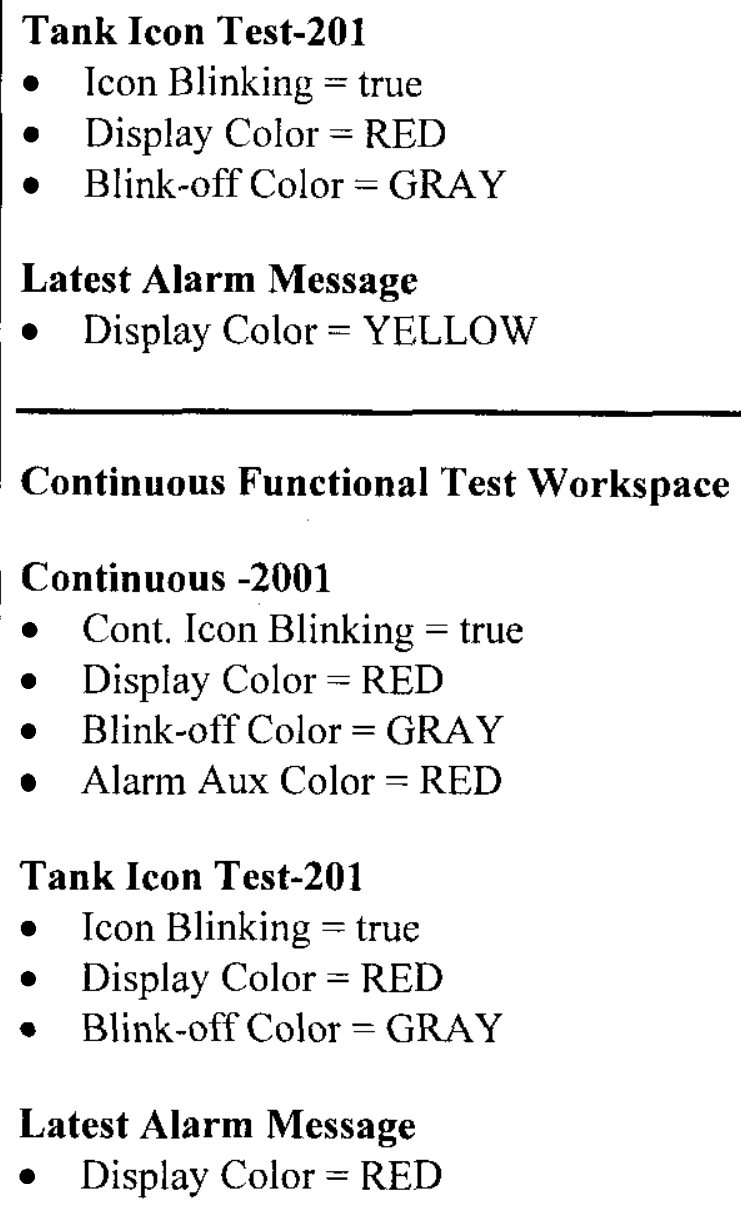 & \\
\hline 5. & $\begin{array}{l}\text { Enter } 1 \text { in Dip-switch type-in box } \\
\text { on the Discrete Functional Test } \\
\text { Workspace. }\end{array}$ & $\begin{array}{l} \\
\text { Most Recent Alarm } \\
\text { - } \quad \text { Message Status = CLOSING } \\
\text { - } \quad \text { Display Color = YELLOW } \\
\text { - Text Color = RED } \\
\text { Discrete Functional Test Workspace } \\
\text { Discrete - 2001 } \\
\text { - } \quad \text { Discrete Icon Blinking = true } \\
\text { - } \quad \text { Display Color = YELLOW } \\
\text { - } \quad \text { Alink-off Color = GRAY Aux Color = YELLOW } \\
\end{array}$ & \\
\hline
\end{tabular}


HNF-3967, Rev. 5

\begin{tabular}{|c|c|c|c|}
\hline Step & Perform & Expected Result & Initial \\
\hline & & 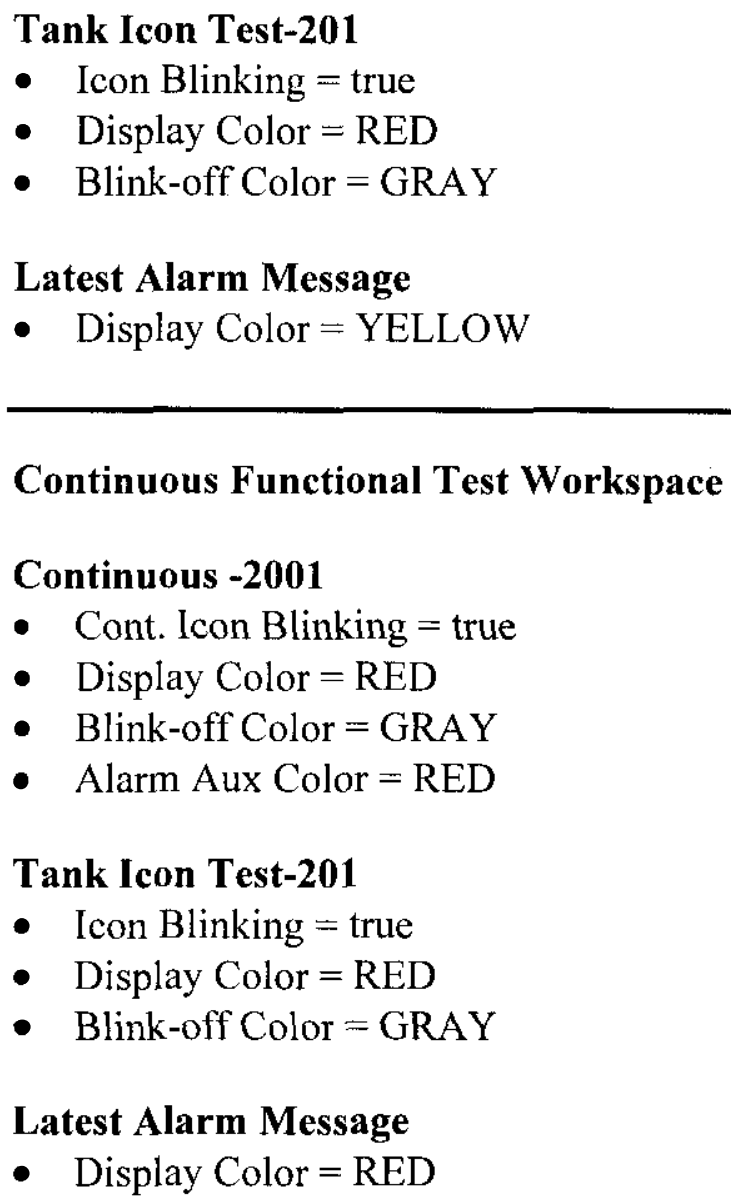 & \\
\hline 6. & $\begin{array}{l}\text { Enter a } 25 \text { in Milli-amp type-in } \\
\text { box on the Continuous } \\
\text { Functional Test Workspace }\end{array}$ & 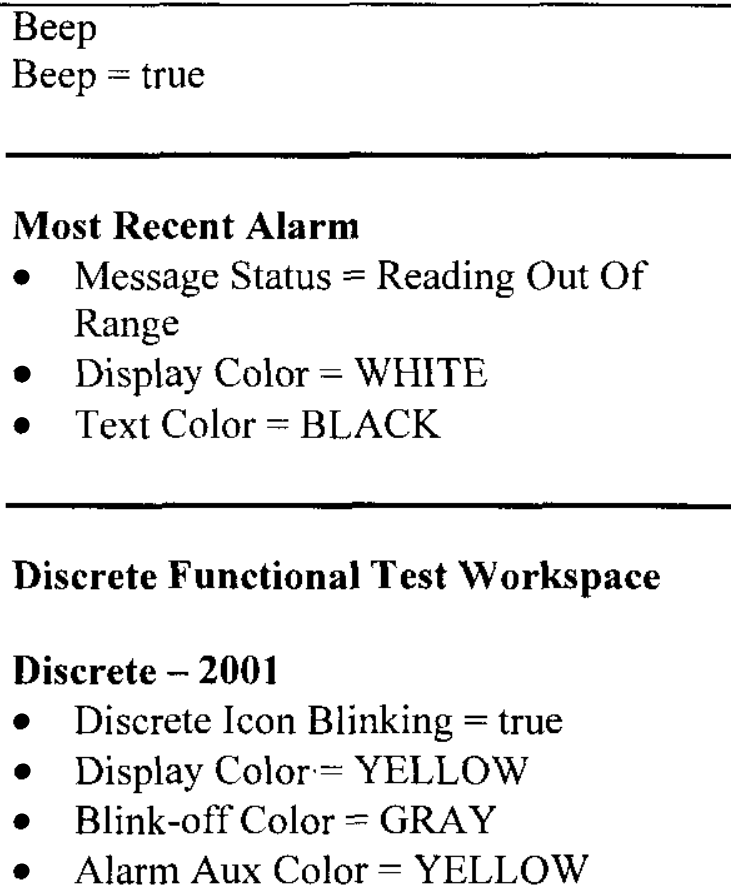 & \\
\hline
\end{tabular}


HNF-3967, Rev. 5

\begin{tabular}{|c|c|c|c|}
\hline Step & Perform & Expected Result & Initial \\
\hline & & 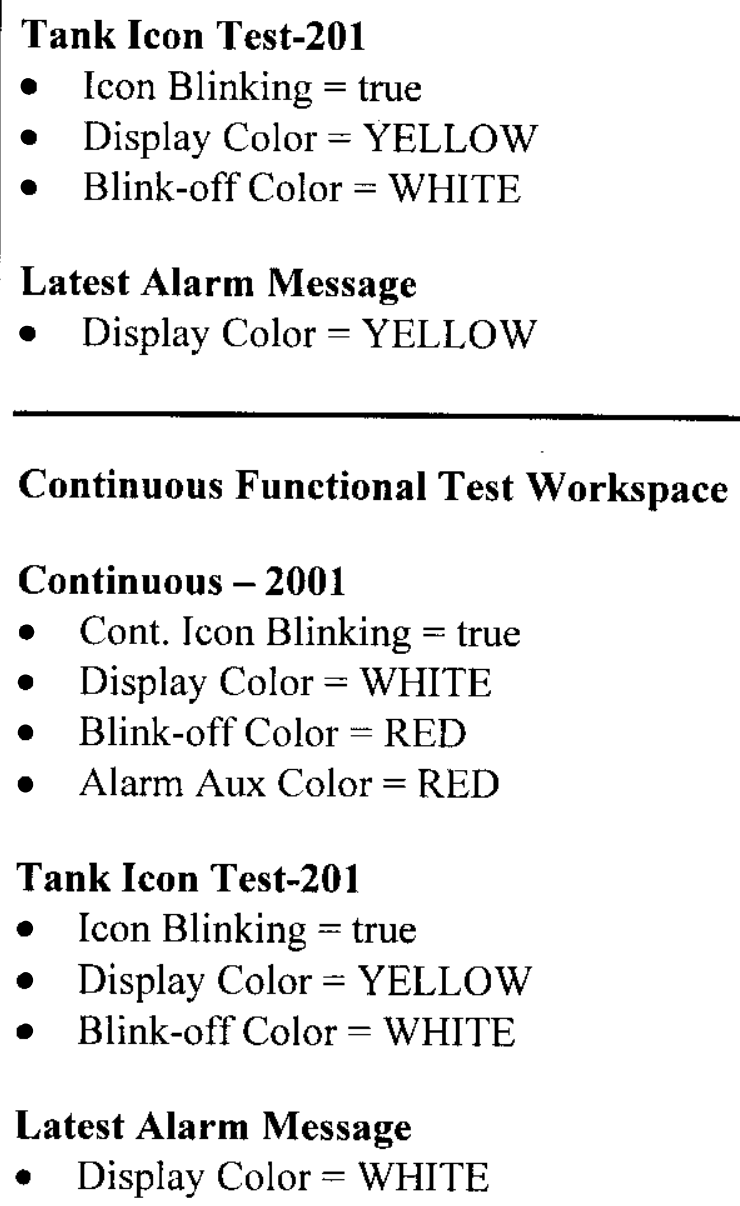 & \\
\hline 7. & $\begin{array}{l}\text { Enter } \underline{\mathbf{3}} \text { in Dip-switch type-in box } \\
\text { on the Discrete Functional Test } \\
\text { Workspace. }\end{array}$ & $\begin{array}{l}\text { Beep } \\
\text { Beep }=\text { true } \\
\text { MOST RECENT ALARM } \\
\text { - } \quad \text { Message Status = Reading Out Of } \\
\text { Range } \\
\text { - } \quad \text { Display Color = WHITE } \\
\text { - } \text { Text Color = BLACK } \\
\text { CURRENT ALARM SCREEN } \\
\text { - Message Status = Discrete 200001 } \\
\text { Resets } \\
\text { Display Color = GREEN } \\
\text { Text Color = BLACK }\end{array}$ & \\
\hline
\end{tabular}


HNF-3967, Rev. 5

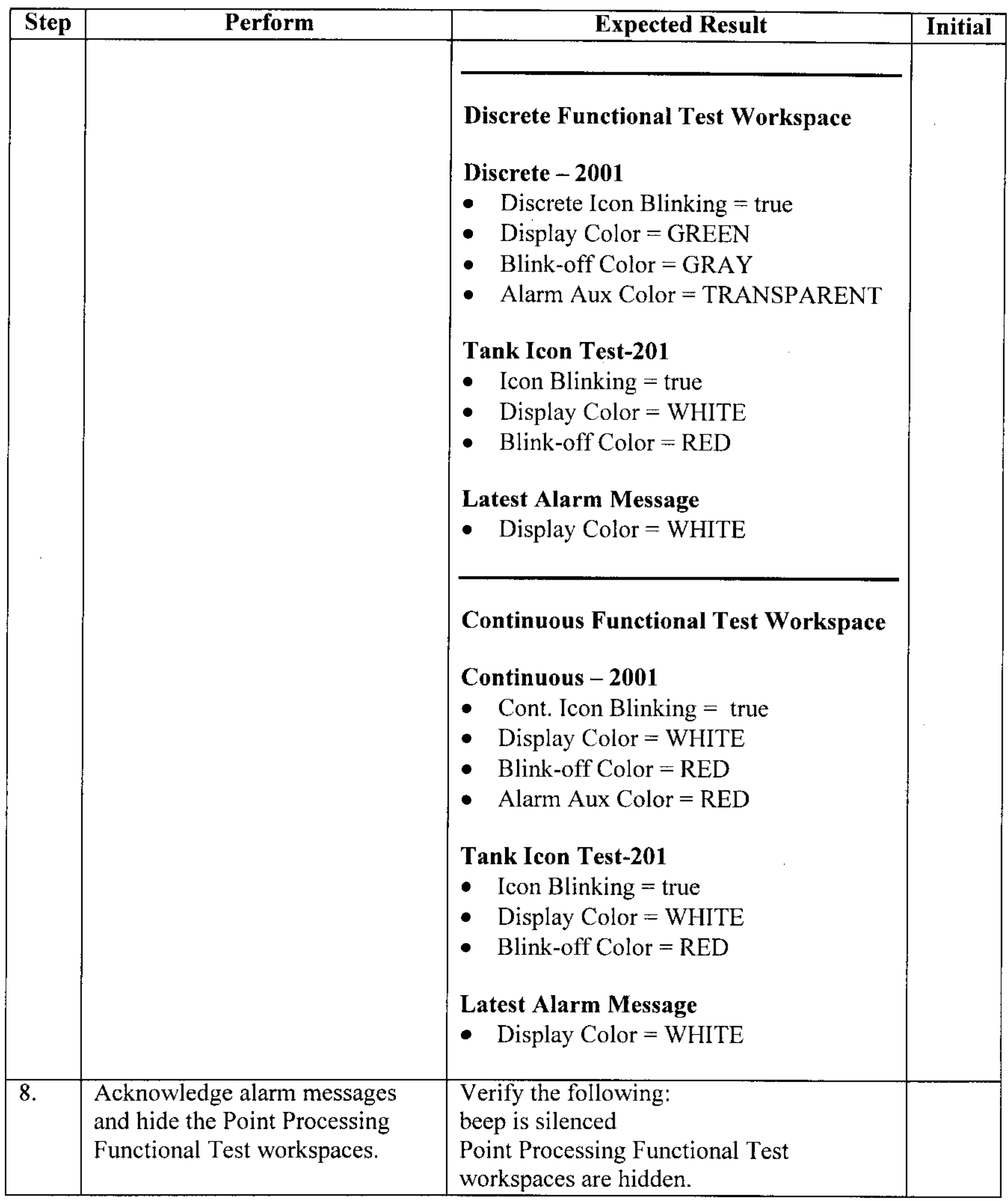

\subsection{LOGGING}

\subsubsection{Current}


The data files in this section are created upon system startup and then around midnight are closed and moved to the history directory and another file with the current date is created.

\subsubsection{Alarm Logging}

\begin{tabular}{|c|c|c|c|}
\hline Step & Perform & Expected Result & Initial \\
\hline 1. & $\begin{array}{l}\text { Examine the } \\
\text { almhst_YYYY_MM_DD_HHmm.dat. } \\
\text { Where } \\
\text { YYYY = the year } \\
\mathrm{MM}=\text { the month } \\
\mathrm{DD}=\text { the day } \\
\mathrm{HH}=\text { the hour } \\
\mathrm{mm}=\text { the minute } \\
\text { To examine the files it may be necessary } \\
\text { to stop G2 } 2^{\circledR} \text {. The directory is located at } \\
\text { f:IBackedUp } \mid T M A C S \text { DatalCurrent. }\end{array}$ & $\begin{array}{l}\text { Verify the following: } \\
\text { - High/low alarm conditions } \\
\text { and resets recorded } \\
\text { - Format match the } \\
\text { description given in } \\
\text { "TMACS As-Built Design } \\
\text { Document" HNF-SD-WM- } \\
\text { SDD-079, Current } \\
\text { Revision. }\end{array}$ & \\
\hline 2. & $\begin{array}{l}\text { Examine the } \\
\text { equip_fail_YYYY_MM_DD_HHmm.dat. } \\
\text { Where } \\
\text { YYYY = the year } \\
\mathrm{MM}=\text { the month } \\
\mathrm{DD}=\text { the day } \\
\mathrm{HH}=\text { the hour } \\
\mathrm{mm}=\text { the minute } \\
\text { To examine the files it may be necessary } \\
\text { to stop G2 } 2^{(\text {Th }} \text {. The directory is located at } \\
\text { f: } \mid \text { BackedUp }|T M A C S D a t a| C u r r e n t .\end{array}$ & $\begin{array}{l}\text { Verify the following } \\
\text { - Loss of communication } \\
\text { messages are recorded } \\
\text { - Format match the } \\
\text { description given in } \\
\text { "TMACS As-Built Design } \\
\text { Document" HNF-SD-WM- } \\
\text { SDD-079, Current } \\
\text { Revision. }\end{array}$ & \\
\hline
\end{tabular}




\subsubsection{Discrete Sensor Data Logging}

\begin{tabular}{|c|c|c|c|}
\hline Step & Perform & Expected Result & Initial \\
\hline 1. & 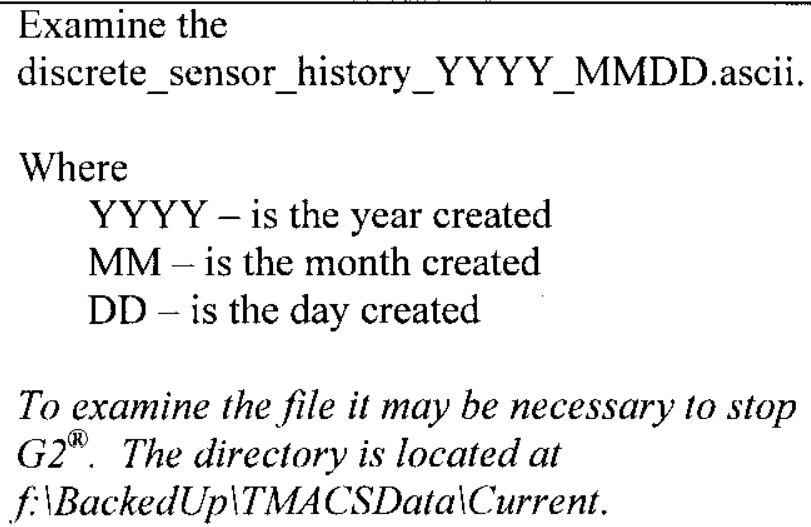 & $\begin{array}{l}\text { Verify the following: } \\
\text { - Reading messages are } \\
\text { being recorded properly. } \\
\text { - Format match the } \\
\text { description given in } \\
\text { "TMACS As-Built } \\
\text { Design Document" } \\
\text { HNF-SD-WM-SDD- } \\
\text { 079, Current Revision.. }\end{array}$ & \\
\hline
\end{tabular}

\subsubsection{Continuous Sensor Data Logging}

Continuous sensor history is recorded in the continuous_sensor_history_YYYY_MMDD.ascii file where

YYYY - is the year that the file was created.

$\mathrm{MM}$ - is the month that the file was created.

$\mathrm{DD}$ - is the day that the file was created.

To examine the file it may be necessary to stop $\mathrm{G}^{\circledR}{ }^{\circledR}$. The directory is:

- $f:$ BackedUp\TMACSDatalCurrent.

\begin{tabular}{|c|c|c|c|}
\hline Step & Perform & Expected Result & Initial \\
\hline 1. & $\begin{array}{l}\text { Examine the continuous_sensor_history } \\
\text { _YYYY_MMDD.ascii. } \\
\text { Where } \\
\text { YYYY - is the year created } \\
\text { MM - is the month created } \\
\text { DD - is the day created } \\
\text { To examine the file it may be necessary to stop } \\
\text { G2 } 2^{\mathbb{B}} \text {. The directory is located at } \\
f: \mid \text { BackedUp }|T M A C S D a t a| C \text { Current. }\end{array}$ & $\begin{array}{l}\text { Verify the following: } \\
\text { - Reading messages are } \\
\text { being recorded properly. } \\
\text { - Format match the } \\
\text { description given in } \\
\text { "TMACS As-Built } \\
\text { Design Document" } \\
\text { HNF-SD-WM-SDD- } \\
\text { 079, Current Revision. }\end{array}$ & \\
\hline
\end{tabular}

\subsubsection{Nightly File Creations}

Eight files are created nightly by TMACS (rdbms files are created around 4:00 AM, all others created around 12:00 AM) 
HNF-3967, Rev. 5

\begin{tabular}{|c|c|c|c|}
\hline Step & Perform & Verify & Initial \\
\hline 1. & $\begin{array}{l}\text { Let the system run over } \\
\text { night. (Note: Test } \\
\text { Director may opt to } \\
\text { change the system clock to } \\
\text { simulate overnight. This } \\
\text { requires time periods } \\
\text { around midnight and } \\
4 A M) \\
\text { Check the location } \\
\text { f: BackedUp\TMACSData } \\
\text { History to determine if } \\
\text { the files have been } \\
\text { created. }\end{array}$ & $\begin{array}{l}\text { Verify that the following flat files are } \\
\text { created: } \\
\text { - almhst_yyyy_mmdd_mmss.dat } \\
\text { - continuous_sensor_history } \\
\text { yyyy_mmdd.ascii } \\
\text { - discrete_sensor_history_yyyy_mmdd } \\
\text {.ascii } \\
\text { - equip_fail_yyyy_mmdd_mmss.dat } \\
\text { - perf_data_yyyy_mmdd.dat } \\
\text { - sacs_data_yyyy_mmdd_mmss.rdbms } \\
\text { where: } \\
\text { yyyy = the year } \\
\text { mm = the month } \\
\text { dd = the day } \\
\text { hh = the hour } \\
\text { mm = the minute } \\
\text { Verify that the fields in the files match } \\
\text { the description given in "TMACS As- } \\
\text { Built Design Document" HNF-SD-WM- W- } \\
\text { SDD-079, Current Revision. }\end{array}$ & \\
\hline
\end{tabular}

\subsection{PERFORMACE}

\subsubsection{CPU Use Vs Number of Continuous Points/Sec Performance Test}

\begin{tabular}{|l|l|l|l|}
\hline Step & \multicolumn{1}{|c|}{ Perform } & \multicolumn{1}{|c|}{ Expected Result } & Initial \\
\hline 1. & $\begin{array}{l}\text { On the Point Processing } \\
\text { Performance Test workspace click } \\
\text { on the "CPU Use Versus Number } \\
\text { of Continuous Points/Sec" } \\
\text { button. }\end{array}$ & $\begin{array}{l}\text { Verify the correct workspace is } \\
\text { shown. }\end{array}$ & \\
\hline 2. & $\begin{array}{l}\text { Click on the "Start Performance } \\
\text { Test" button. }\end{array}$ & $\begin{array}{l}\text { Verify the test runs and that the } \\
\text { \%CPU/pt/sec values are less than } \\
0.94 \text { for all values of } \\
\text { points/second. }\end{array}$ & \\
& $\begin{array}{l}\text { After the Test Running box turns } \\
\text { to FALSE examine the results. } \\
\text { (The test will take about } \\
\text { 20 minutes to run })\end{array}$ & & \\
\hline
\end{tabular}


HNF-3967, Rev. 5

\begin{tabular}{|l|l|l|l|}
\hline Step & \multicolumn{1}{|c|}{ Perform } & \multicolumn{1}{|c|}{ Expected Result } & Initial \\
\hline 3. & Click on the "Print" button. & $\begin{array}{l}\text { Verify that the workspace prints. } \\
\text { Attach the printout to this test } \\
\text { procedure. }\end{array}$ & \\
\hline 4. & $\begin{array}{l}\text { Hide the Performance Test } \\
\text { workspace(s) }\end{array}$ & $\begin{array}{l}\text { Verify the workspace(s) is } \\
\text { hidden. }\end{array}$ & \\
\hline
\end{tabular}

\subsubsection{CPU Use Vs Number of Discrete Points/Sec Performance Test}

\begin{tabular}{|c|c|c|c|}
\hline Step & Perform & Expected Result & Initial \\
\hline 1. & $\begin{array}{l}\text { On the Point Processing } \\
\text { Performance Test workspace click } \\
\text { on the "CPU Use Versus Number } \\
\text { of Discrete Points/Sec" button. }\end{array}$ & $\begin{array}{l}\text { Verify the correct Performance } \\
\text { Test workspace is shown. }\end{array}$ & \\
\hline 2. & $\begin{array}{l}\text { Click on the "Start Performance } \\
\text { Test" button. } \\
\text { After the Test Running box turns } \\
\text { to FALSE examine the results. } \\
\text { (The test will take about } \\
20 \text { minutes to run) }\end{array}$ & $\begin{array}{l}\text { Verify that the test runs and that } \\
\text { the } \% \mathrm{CPU} / \mathrm{pt} / \mathrm{sec} \text { values are less } \\
\text { than } 0.82 \text { for all values of } \\
\text { points } / \mathrm{second} \text {. }\end{array}$ & \\
\hline 3. & Click on the "Print" button. & $\begin{array}{l}\text { Verify that the workspace prints. } \\
\text { Attach the printout to this test } \\
\text { procedure. }\end{array}$ & \\
\hline 4. & $\begin{array}{l}\text { Hide the Performance Test } \\
\text { workspace(s) }\end{array}$ & $\begin{array}{l}\text { Verify the workspace(s) is } \\
\text { hidden. }\end{array}$ & \\
\hline
\end{tabular}

\subsubsection{CPU Use Vs Pt-Processing Function for Continuous Points Performance Test}

\begin{tabular}{|l|l|l|l|}
\hline Step & \multicolumn{1}{|c|}{ Perform } & \multicolumn{1}{|c|}{ Expected Result } & Initial \\
\hline 1. & $\begin{array}{l}\text { On the Point Processing } \\
\text { Performance Test workspace } \\
\text { click on the Click on the }\end{array}$ & $\begin{array}{l}\text { Verify the correct Performance Test } \\
\text { workspace is shown. }\end{array}$ & \\
& $\begin{array}{l}\text { Processing Function for } \\
\text { Continuous Points" button. }\end{array}$ & & \\
\hline
\end{tabular}


HNF-3967, Rev. 5

\begin{tabular}{|l|l|l|l|}
\hline Step & \multicolumn{1}{|c|}{ Perform } & \multicolumn{1}{|c|}{ Expected Result } & Initial \\
\hline 2. & $\begin{array}{l}\text { Click on the "Start } \\
\text { Performance Test" button. }\end{array}$ & $\begin{array}{l}\text { Verify that the test runs and that for } \\
\text { each Point Processing Breakdown } \\
\text { that the following criteria are met. }\end{array}$ & \\
& $\begin{array}{l}\text { After the Test Running box } \\
\text { turns to FALSE examine the } \\
\text { results. (The test will take } \\
\text { about } 20 \text { minutes } \text { to } \text { run })\end{array}$ & $\begin{array}{l}0.23 \\
\text { Delta Check the \%CPU per points/sec } \\
<0.15 \\
\text { Alarm Check the \%CPU per } \\
\text { points/sec }<0.07 \\
\text { ROC Check the \%CPU per points/sec } \\
<0.12 \\
\text { Log to Disk the \%CPU per points/sec } \\
<0.57\end{array}$ & \\
& & $\begin{array}{l}\text { Verify that the workspace prints. } \\
\text { Attach the printout to this test } \\
\text { procedure. }\end{array}$ & \\
\hline 3. & Click on the "Print" button. & \\
\hline 4. & Hide the Performance Test & Verify the workspace is hidden. & \\
\hline
\end{tabular}

\subsubsection{CPU Use Vs Point-Processing Function for Discrete Points Performance Test}

\begin{tabular}{|c|c|c|c|}
\hline Step & Perform & Expected Result & Initial \\
\hline 1 . & $\begin{array}{l}\text { On the Point Processing } \\
\text { Performance Test } \\
\text { workspace click on the } \\
\text { Click on the "CPU Use } \\
\text { Versus Point-Processing } \\
\text { Function for Discrete } \\
\text { Points" button. }\end{array}$ & $\begin{array}{l}\text { Verify the correct Performance Test } \\
\text { workspace is shown. }\end{array}$ & \\
\hline 2. & $\begin{array}{l}\text { Click on the "Start } \\
\text { Performance Test" button. } \\
\text { After the Test Running } \\
\text { box turns to FALSE } \\
\text { examine the results. (The } \\
\text { test will take about } \\
20 \text { minutes to run) }\end{array}$ & $\begin{array}{l}\text { Verify that the test runs and that for each } \\
\text { Point Processing Breakdown that the } \\
\text { following criteria are met. } \\
\text { for Update Pt. the } \% \mathrm{CPU} \text { per points } / \mathrm{sec} \\
<0.28 \\
\text { for Alarm Check the } \% \mathrm{CPU} \text { per } \\
\text { points } / \mathrm{sec}<0.07 \\
\text { for Log to Disk the } \% \mathrm{CPU} \text { per points } / \mathrm{sec} \\
<0.57\end{array}$ & \\
\hline 3. & $\begin{array}{l}\text { Click on the "Print" } \\
\text { button. }\end{array}$ & $\begin{array}{l}\text { Verify that the workspace prints. } \\
\text { Attach the printout to this test procedure. }\end{array}$ & \\
\hline 4. & $\begin{array}{l}\text { Hide the Performance } \\
\text { Test workspace }\end{array}$ & Verify the workspace is hidden. & \\
\hline
\end{tabular}


HNF-3967, Rev. 5

\subsection{SERVICE REQUESTS}

\subsubsection{SR 455 - Make the Unit of Measure for Enrafs consistent}

\begin{tabular}{|l|l|l|c|}
\hline Step & Perform & Verify & Initial \\
\hline 1. & $\begin{array}{l}\text { Using the Inspect command, } \\
\text { have the system administrator } \\
\text { display the Units of Measure } \\
\text { (UNITS) for Enraf Levels. }\end{array}$ & $\begin{array}{l}\text { Verify the unit of measure is inches instead } \\
\text { of inch. }\end{array}$ & \\
\hline
\end{tabular}

\subsubsection{SR 711 - Correct The Acromag remote procedure "Write Digital"}

\begin{tabular}{|l|l|l|l|}
\hline Step & Perform & Verify & Initial \\
\hline 1. & $\begin{array}{l}\text { Have system administrator issue } \\
\text { a "Write Digital" remote } \\
\text { procedure command to an } \\
\text { Acromag chosen at random. }\end{array}$ & Verify the command operates correctly. & \\
\hline
\end{tabular}

\subsubsection{SR 878 - Fix Suspect I/O Report Abort Problem}

\begin{tabular}{|l|l|l|l|}
\hline Step & Perform & Verify & Initial \\
\hline 1. & $\begin{array}{l}\text { Have the system administrator } \\
\text { set up the system so that the } 100 \\
\text { Area Acromag station is in the } \\
\text { failed mode. }\end{array}$ & $\begin{array}{l}\text { Verify the report does not abort and that it } \\
\text { displays the proper information. } \\
\text { Using the reports menu display } \\
\text { the Suspect Station I/O Report. }\end{array}$ & \\
\hline
\end{tabular}

\subsubsection{SR 879 - Fix Reports So The Number Found Matches The Number Displayed}

\begin{tabular}{|c|c|c|c|}
\hline Step & Perform & Verify & Initial \\
\hline 1. & $\begin{array}{l}\text { Using the reports menu select } \\
\text { the Suspect I/O Station Report. }\end{array}$ & Verify the report is displayed properly. & \\
\hline 2. & Enable sort for the report. & Verify the Sorted check box has an $\mathbf{X}$ in it. & \\
\hline 3. & $\begin{array}{l}\text { Select the update button. } \\
\text { Before the report has finished } \\
\text { cause one or more I/O stations to } \\
\text { change status (good or bad). }\end{array}$ & $\begin{array}{l}\text { When the report completes verify the } \\
\text { following: } \\
\text { - The report reflects the changed stations } \\
\text { statuses. } \\
\text { - The "Number of Suspect Stations" } \\
\text { equals the "Station Insert Count". }\end{array}$ & \\
\hline
\end{tabular}




\subsubsection{S80 - Make Unacknowledge Alarms Stop Blinking when Alarm Processing is Disabled}

\begin{tabular}{|l|l|l|l|}
\hline Step & Perform & Verify & Initial \\
\hline 1. & $\begin{array}{l}\text { Select a sensor at random and } \\
\text { cause it to go into an alarm } \\
\text { condition. Important do not } \\
\text { acknowledge the alarm. }\end{array}$ & $\begin{array}{l}\text { Verify the following: } \\
\text { An alarm is displayed on the current } \\
\text { alarms workspace. } \\
\text { The icon representing the sensor is the } \\
\text { appropriate alarm color and is blinking. }\end{array}$ & $\begin{array}{l}\text { Have the system administrator } \\
\text { disable the alarm processing for }\end{array}$ \\
\hline 2. & $\begin{array}{l}\text { Verify the following: } \\
\text { Thesen sensor. }\end{array}$ & $\begin{array}{l}\text { The alarm message on the current } \\
\text { alarms disappears } \\
\text { A blue message is display on the current } \\
\text { alarm screen indicating the sensor had } \\
\text { the alarm processing disabled. } \\
\text { The icon representing the sensor is } \\
\text { green and not blinking. }\end{array}$ & \\
\hline
\end{tabular}

\subsubsection{SR 884 - Fix Remote Procedure Calls So Limit Of 4096 Is Not Reached}

\begin{tabular}{|c|c|c|c|}
\hline Step & Perform & Verify & Initial \\
\hline 1. & $\begin{array}{l}\text { Have the system administrator } \\
\text { start the old Acromag, Enraf and } \\
\text { Westronic drivers. } \\
\text { Have the system administrator } \\
\text { display the internal counter "G2- } \\
\text { OPEN-RPC-CALL-COUNT" } \\
\text { Have the system administrator } \\
\text { initialize the internal counter. }\end{array}$ & $\begin{array}{l}\text { Verify the counter's Last Recorded Value is } \\
\text { set to } 0.0 \text {. }\end{array}$ & \\
\hline 2. & $\begin{array}{l}\text { Request a sensor update from a } \\
\text { sensor connected to one of the } \\
\text { following stations: } \\
\text { - Acromag } \\
\text { - Enraf } \\
\text { - Westronics }\end{array}$ & $\begin{array}{l}\text { Verify the counter's Last Record Value is } \\
\text { not updated }\end{array}$ & \\
\hline 3. & Have the system administrator & Verify the counter's Last Recorded Value is & \\
\hline
\end{tabular}




\begin{tabular}{|c|c|c|}
\hline & $\begin{array}{l}\text { start the new Acromag, Enraf } \\
\text { and Westronic drivers. } \\
\text { Have the system administrator } \\
\text { initialize the internal counter } \\
\text { "G2-OPEN-RPC-CALL- } \\
\text { COUNT". }\end{array}$ & set to 0.0 \\
\hline 4. & $\begin{array}{l}\text { Request a sensor update from a } \\
\text { sensor connected to an Acromag } \\
\text { station. }\end{array}$ & $\begin{array}{l}\text { Verify the counter 's Last Record Value is } \\
\text { updated }\end{array}$ \\
\hline 5. & $\begin{array}{l}\text { Have the system administrator } \\
\text { initialize the internal counter } \\
\text { "G2-OPEN-RPC-CALL- } \\
\text { COUNT". }\end{array}$ & $\begin{array}{l}\text { Verify the counter's Last Recorded Value is } \\
\text { set to } 0.0 \text {. }\end{array}$ \\
\hline 6. & $\begin{array}{l}\text { Request a sensor update from a } \\
\text { sensor connected to an Enraf } \\
\text { station. }\end{array}$ & $\begin{array}{l}\text { Verify the counter 's Last Record Value is } \\
\text { updated }\end{array}$ \\
\hline 7. & $\begin{array}{l}\text { Have the system administrator } \\
\text { initialize the internal counter } \\
\text { "G2-OPEN-RPC-CALL- } \\
\text { COUNT". }\end{array}$ & $\begin{array}{l}\text { Verify the counter's Last Recorded Value is } \\
\text { set to } 0.0 \text {. }\end{array}$ \\
\hline 8. & $\begin{array}{l}\text { Request a sensor update from a } \\
\text { sensor connected to an } \\
\text { Westronics station. }\end{array}$ & $\begin{array}{l}\text { Verify the counter 's Last Record Value is } \\
\text { updated }\end{array}$ \\
\hline
\end{tabular}

\subsubsection{SR 885 - Create a function to raise the CIU Enraf displacers on a routine basis}

\begin{tabular}{|c|c|c|c|}
\hline Step & Perform & Verify & Initial \\
\hline 1. & $\begin{array}{l}\text { Connect the development Enraf } \\
\text { CIU to the development } \\
\text { computer. } \\
\text { Have the system administrator } \\
\text { issue an Enraf test gauge } \\
\text { command. }\end{array}$ & $\begin{array}{l}\text { Verify the Enraf performs the Enraf test } \\
\text { gauge function properly. }\end{array}$ & \\
\hline 2. & $\begin{array}{l}\text { Connect the Enraf Emulator to } \\
\text { the development computer. } \\
\text { Have the system administrator } \\
\text { configure Enraf gauges to } \\
\text { perform test gauges (both } 24 \mathrm{hr} \\
\text { and } 8 \mathrm{hr} \text { cycles.) } \\
\text { Have the system administrator } \\
\text { issue a } 24 \text {-hr test gauge cycle. }\end{array}$ & $\begin{array}{l}\text { Using the serial analyzer, verify that test } \\
\text { gauge commands are issued to the Enrafs } \\
\text { configured (both the } 8 \mathrm{hr} \text { and } 24 \mathrm{hr} \text { cycles). } \\
\text { Note: (The commands should be metered } \\
\text { out at a prescribe amount, currently set at } \\
\text { 10) }\end{array}$ & \\
\hline
\end{tabular}




\begin{tabular}{|l|l|l|l|}
\hline 3. & $\begin{array}{l}\text { Have the system administrator } \\
\text { issue an 8-hr test gauge cycle. }\end{array}$ & $\begin{array}{l}\text { Using the serial analyzer, verify that test } \\
\text { gauge commands are issued to only the } \\
\text { Enrafs configured for the } 8 \mathrm{hr} \text { cycle. }\end{array}$ & \\
\hline 4. & Run the system overnight. & $\begin{array}{l}\text { Verify the test gauge cycles were issued to } \\
\text { the appropriate Enrafs at the correct time. }\end{array}$ & \\
\hline
\end{tabular}

\subsubsection{SR 889 - 200 inch Acromag Conversion Formula}

\begin{tabular}{|l|l|l|c|}
\hline Step & Perform & Verify & Initial \\
\hline 1. & $\begin{array}{l}\text { Have the system administrator } \\
\text { display the function G2 Function } \\
\text { "SurLev-convert-200 }(\mathrm{x}) "\end{array}$ & Verify the function is as follows: & SurLev-convert-200=(0.02*x) \\
\hline
\end{tabular}

\subsubsection{SR 890 - Configure CIU Enrafs for Tank SY101.}

\begin{tabular}{|c|c|c|c|}
\hline Step & Perform & Verify & Initial \\
\hline 1. & $\begin{array}{l}\text { Display the workspace for Tank } \\
\text { SY101. } \\
\text { Select the Details for the Enraf } \\
\text { displayed. }\end{array}$ & $\begin{array}{l}\text { Verify the following: } \\
\text { Tag Name - SY101-LI-R01A-03 } \\
\text { Formula - the waste level of E-L-STA-06- } \\
04-04-41\end{array}$ & \\
\hline 2. & $\begin{array}{l}\text { Using the Sensor Details Update } \\
\text { function request a reading. }\end{array}$ & $\begin{array}{l}\text { Verify the current reading is retrieved and } \\
\text { displayed properly. }\end{array}$ & \\
\hline 3. & $\begin{array}{l}\text { Display the subworkspace for } \\
\text { Tank SY101 that contains the } \\
\text { sensor SY101-LI-R01C-01. } \\
\text { Select the sensor details for } \\
\text { SY101-LI-R01C-01. }\end{array}$ & $\begin{array}{l}\text { Verify the following: } \\
\text { Tag Name - SY101-LI-R01C-01 } \\
\text { Formula - the waste level of E-L-STA-06- } \\
04-04-43\end{array}$ & \\
\hline 4. & $\begin{array}{l}\text { Using the Sensor Details Update } \\
\text { function request a reading. }\end{array}$ & $\begin{array}{l}\text { Verify the current reading is retrieved and } \\
\text { displayed properly. }\end{array}$ & \\
\hline
\end{tabular}

\subsubsection{SR 891 - Change Instrument Limits for SY103 Enraf}

\begin{tabular}{|l|l|l|c|}
\hline Step & Perform & Verify & Initial \\
\hline 5. & $\begin{array}{l}\text { Display the Sensor Details for } \\
\text { the sensor SY103-LI-R02A-01. }\end{array}$ & Verify the following: & \\
& & $\begin{array}{l}\text { Low Instrument Limit }-0.0 \\
\text { High Instrument Limit }-500.0\end{array}$ & \\
\hline
\end{tabular}




\subsubsection{SR 892 - Support the transfer of CASS Alarms to TMACS}

\begin{tabular}{|c|c|c|c|}
\hline Step & Perform & Verify & Initial \\
\hline 1. & $\begin{array}{l}\text { Have the system administrator } \\
\text { display the alarm groups } \\
\text { associated with the following: } \\
\text { Tank Farm Alarm Groups } \\
\text { - A } \\
\text { - } \text { AN } \\
\text { - } \text { AP } \\
\text { - } \text { AW } \\
\text { - } \text { BY } \\
\text { - } \text { C } \\
\text { - } \text { SX } \\
\text { - SY } \\
\text { In-Between Farms Alarm } \\
\text { Groups } \\
\text { - } 204 \mathrm{AR} \\
\text { - } 242 \mathrm{~A} \\
\text { - } 242 \mathrm{~S} \\
\text { - } 242 \mathrm{~T} \\
\text { - } 702 \mathrm{AZ}\end{array}$ & $\begin{array}{l}\text { Using the tag list verify the following: } \\
\text { - Alarm Window Text } \\
\text { - Alarm Panel Location } \\
\text { - Alarm Color }\end{array}$ & \\
\hline 2. & $\begin{array}{l}\text { Select a few sensors at random } \\
\text { from the alarm groups } \\
\text { mentioned in step } 1 . \\
\text { Using the Acromag emulator } \\
\text { generate an alarm followed by a } \\
\text { reset. }\end{array}$ & $\begin{array}{l}\text { Verify that the appropriate alarm is } \\
\text { generated and reset properly. }\end{array}$ & \\
\hline
\end{tabular}

\subsubsection{SR 899 - Move RAWDATA Insert Process onto TMACSPROD}

\begin{tabular}{|l|l|l|l|}
\hline Step & Perform & Verify & Initial \\
\hline 1. & $\begin{array}{l}\text { Have the system } \\
\text { administrator set up the } \\
\text { TMACS system so that } \\
\text { the nightly RAWDATA } \\
\text { inserts is performed. }\end{array}$ & $\begin{array}{l}\text { Verify the following: } \\
\text { Verify the following file is created the } \\
\text { continuous_sensor_history_YYYY_MMDD.ascii. } \\
\text { Where } \\
\text { YYYY - is the year created } \\
\text { MM - is the month created }\end{array}$ & \\
\hline
\end{tabular}




\begin{tabular}{|l|l|l|}
\hline \multicolumn{1}{|l|}{} & $\begin{array}{l}\text { DD - is the day created } \\
\text { Note: The format was verified in step } 6.7 .1 .3 \\
\text { Continuous Sensor Data Logging }\end{array}$ \\
$\begin{array}{l}\text { Verify the data was inserted into the SACS } \\
\text { database properly. (Note: During this test the } \\
\text { server which the database is located is } \\
\text { TMACSDEV) }\end{array}$ & \\
\hline
\end{tabular}

\subsubsection{SR 902 - Modify TMACS to insert SACS nightly Reading Directly}

\begin{tabular}{|c|c|c|c|}
\hline Step & Perform & Verify & Initial \\
\hline 1. & $\begin{array}{l}\text { Have the system administrator } \\
\text { set up the TMACS system so } \\
\text { that the nightly SACS inserts is } \\
\text { performed. }\end{array}$ & $\begin{array}{l}\text { Verify the following: } \\
\text { Verify the following file is created } \\
\text { sacs_data_yyyy_mmdd_mmss.rdbms } \\
\text { where: } \\
\quad \text { yyyy = the year } \\
\mathrm{mm}=\text { the month } \\
\mathrm{dd}=\text { the day } \\
\mathrm{hh}=\text { the hour } \\
\mathrm{mm}=\text { the minute } \\
\text { Note: The format was verified in step } 6.7 .2 \\
\text { Nightly File Creations } \\
\text { Verify the data was inserted into the SACS } \\
\text { database properly. (Note: During this test } \\
\text { the server which the database is located is } \\
\text { UDO) }\end{array}$ & \\
\hline
\end{tabular}

\subsubsection{SR 903 - Update Operating System to NT 4.0 Service Pack 5.0}

\begin{tabular}{|l|l|l|c|}
\hline Step & Perform & Verify & Initial \\
\hline 1. & $\begin{array}{l}\text { Have the system administrator } \\
\text { display the About NT screen } \\
\text { located in the following: } \\
\text { My Computer > Help >About NT }\end{array}$ & Verify the screen identifies the version as: & NT 4.0 Service Pack (SP) 5 \\
\hline
\end{tabular}


6.9.15 SR 914 - Change Gauge Address for Enrafs in Tanks AX101 - AX104, AY101 and AY102

\begin{tabular}{|c|c|c|c|}
\hline Step & Perform & Verify & Initial \\
\hline 1. & $\begin{array}{l}\text { Display the workspace for Tank } \\
\text { AX101. } \\
\text { Select the Details for the Enraf } \\
\text { displayed. }\end{array}$ & $\begin{array}{l}\text { Verify the following: } \\
\text { Tag Name-AX101-LI-R08C-01 } \\
\text { Formula - the waste level of E-L-STA-06- } \\
00-00-61\end{array}$ & \\
\hline 2. & $\begin{array}{l}\text { Using the Sensor Details Update } \\
\text { function request a reading. }\end{array}$ & $\begin{array}{l}\text { Verify the current reading is retrieved and } \\
\text { displayed properly. }\end{array}$ & \\
\hline 3. & $\begin{array}{l}\text { Display the workspace for Tank } \\
\text { AX102. } \\
\text { Select the Details for the Enraf } \\
\text { displayed. }\end{array}$ & $\begin{array}{l}\text { Verify the following: } \\
\text { Tag Name - AX102-LI-R09B-01 } \\
\text { Formula - the waste level of E-L-STA-06- } \\
00-00-62\end{array}$ & \\
\hline 4. & $\begin{array}{l}\text { Using the Sensor Details Update } \\
\text { function request a reading. }\end{array}$ & $\begin{array}{l}\text { Verify the current reading is retrieved and } \\
\text { displayed properly. }\end{array}$ & \\
\hline 5. & $\begin{array}{l}\text { Display the workspace for Tank } \\
\text { AX103. } \\
\text { Select the Details for the Enraf } \\
\text { displayed. }\end{array}$ & $\begin{array}{l}\text { Verify the following: } \\
\text { Tag Name - AX103-LI-R09C-01 } \\
\text { Formula - the waste level of E-L-STA-06- } \\
00-00-63\end{array}$ & \\
\hline 6. & $\begin{array}{l}\text { Using the Sensor Details Update } \\
\text { function request a reading. }\end{array}$ & $\begin{array}{l}\text { Verify the current reading is retrieved and } \\
\text { displayed properly. }\end{array}$ & \\
\hline 7. & $\begin{array}{l}\text { Display the workspace for Tank } \\
\text { AX104. } \\
\text { Select the Details for the Enraf } \\
\text { displayed. }\end{array}$ & $\begin{array}{l}\text { Verify the following: } \\
\text { Tag Name - AX104-LI-R09B-01 } \\
\text { Formula - the waste level of E-L-STA-06- } \\
00-00-64\end{array}$ & \\
\hline 8. & $\begin{array}{l}\text { Using the Sensor Details Update } \\
\text { function request a reading. }\end{array}$ & $\begin{array}{l}\text { Verify the current reading is retrieved and } \\
\text { displayed properly. }\end{array}$ & \\
\hline 9. & $\begin{array}{l}\text { Display the workspace for Tank } \\
\text { AY101. } \\
\text { Select the Details for the Enraf } \\
\text { displayed. }\end{array}$ & $\begin{array}{l}\text { Verify the following: } \\
\text { Tag Name - AY101-LI-R22A-01 } \\
\text { Formula - the waste level of E-L-STA-06- } \\
00-00-65\end{array}$ & \\
\hline 10. & $\begin{array}{l}\text { Using the Sensor Details Update } \\
\text { function request a reading. }\end{array}$ & $\begin{array}{l}\text { Verify the current reading is retrieved and } \\
\text { displayed properly. }\end{array}$ & \\
\hline 11. & $\begin{array}{l}\text { Display the workspace for Tank } \\
\text { AY102. } \\
\text { Select the Details for the Enraf } \\
\text { displayed. }\end{array}$ & $\begin{array}{l}\text { Verify the following: } \\
\text { Tag Name - AY102-LI-R22A-01 } \\
\text { Formula - the waste level of E-L-STA-06- } \\
00-00-66\end{array}$ & \\
\hline 12. & $\begin{array}{l}\text { Using the Sensor Details Update } \\
\text { function request a reading. }\end{array}$ & $\begin{array}{l}\text { Verify the current reading is retrieved and } \\
\text { displayed properly. }\end{array}$ & \\
\hline
\end{tabular}


6.9.16 SR 915 - Add Enrafs To Tanks AZ102, AZ151, B101-B112, and B201-B204

\begin{tabular}{|c|c|c|c|}
\hline Step & Perform & Verify & Initial \\
\hline 1. & $\begin{array}{l}\text { Display the workspace for Tank } \\
\text { AZ102. } \\
\text { Select the Details for the Enraf } \\
\text { displayed. }\end{array}$ & $\begin{array}{l}\text { Verify the following: } \\
\text { Tag Name - AZ102-LI-R24A-01 } \\
\text { Formula - the waste level of E-L-STA-06- } \\
00-00-68\end{array}$ & \\
\hline 2. & $\begin{array}{l}\text { Using the Sensor Details Update } \\
\text { function request a reading. }\end{array}$ & $\begin{array}{l}\text { Verify the current reading is retrieved and } \\
\text { displayed properly. }\end{array}$ & \\
\hline 3. & $\begin{array}{l}\text { Display the workspace for Tank } \\
\text { AZ151. } \\
\text { Select the Details for the Enraf } \\
\text { displayed. }\end{array}$ & $\begin{array}{l}\text { Verify the following: } \\
\text { Tag Name - AZ151-LI-R000-01 } \\
\text { Formula - the waste level of E-L-STA-06- } \\
00-00-16\end{array}$ & \\
\hline 4. & $\begin{array}{l}\text { Using the Sensor Details Update } \\
\text { function request a reading. }\end{array}$ & $\begin{array}{l}\text { Verify the current reading is retrieved and } \\
\text { displayed properly. }\end{array}$ & \\
\hline 5. & $\begin{array}{l}\text { Display the workspace for Tank } \\
\text { B101. } \\
\text { Select the Details for the Enraf } \\
\text { displayed. }\end{array}$ & $\begin{array}{l}\text { Verify the following: } \\
\text { Tag Name - B101-LI-R008-01 } \\
\text { Formula - the waste level of E-L-STA-06- } \\
\text { 06-06-01 }\end{array}$ & \\
\hline 6. & $\begin{array}{l}\text { Using the Sensor Details Update } \\
\text { function request a reading. }\end{array}$ & $\begin{array}{l}\text { Verify the current reading is retrieved and } \\
\text { displayed properly. }\end{array}$ & \\
\hline 7. & $\begin{array}{l}\text { Display the workspace for Tank } \\
\text { B102. } \\
\text { Select the Details for the Enraf } \\
\text { displayed. }\end{array}$ & $\begin{array}{l}\text { Verify the following: } \\
\text { Tag Name - B102-LI-R001-01 } \\
\text { Formula - the waste level of E-L-STA-06- } \\
06-06-02\end{array}$ & \\
\hline 8. & $\begin{array}{l}\text { Using the Sensor Details Update } \\
\text { function request a reading. }\end{array}$ & $\begin{array}{l}\text { Verify the current reading is retrieved and } \\
\text { displayed properly. }\end{array}$ & \\
\hline 9. & $\begin{array}{l}\text { Display the workspace for Tank } \\
\text { B103. } \\
\text { Select the Details for the Enraf } \\
\text { displayed. }\end{array}$ & $\begin{array}{l}\text { Verify the following: } \\
\text { Tag Name - B103-LI-R001-01 } \\
\text { Formula - the waste level of E-L-STA-06- } \\
06-06-03\end{array}$ & \\
\hline 10. & $\begin{array}{l}\text { Using the Sensor Details Update } \\
\text { function request a reading. }\end{array}$ & $\begin{array}{l}\text { Verify the current reading is retrieved and } \\
\text { displayed properly. }\end{array}$ & \\
\hline 11. & $\begin{array}{l}\text { Display the workspace for Tank } \\
\text { B104. } \\
\text { Select the Details for the Enraf } \\
\text { displayed. }\end{array}$ & $\begin{array}{l}\text { Verify the following: } \\
\text { Tag Name - B104-LI-R008-01 } \\
\text { Formula - the waste level of E-L-STA-06- } \\
06-06-04\end{array}$ & \\
\hline 12. & $\begin{array}{l}\text { Using the Sensor Details Update } \\
\text { function request a reading. }\end{array}$ & $\begin{array}{l}\text { Verify the current reading is retrieved and } \\
\text { displayed properly. }\end{array}$ & \\
\hline
\end{tabular}




\begin{tabular}{|c|c|c|}
\hline 13. & $\begin{array}{l}\text { Display the workspace for Tank } \\
\text { B105. } \\
\text { Select the Details for the Enraf } \\
\text { displayed. }\end{array}$ & $\begin{array}{l}\text { Verify the following: } \\
\text { Tag Name - B105-LI-R014-01 } \\
\text { Formula - the waste level of E-L-STA-06- } \\
06-06-05\end{array}$ \\
\hline 14. & $\begin{array}{l}\text { Using the Sensor Details Update } \\
\text { function request a reading. }\end{array}$ & $\begin{array}{l}\text { Verify the current reading is retrieved and } \\
\text { displayed properly. }\end{array}$ \\
\hline 15. & $\begin{array}{l}\text { Display the workspace for Tank } \\
\text { B106. } \\
\text { Select the Details for the Enraf } \\
\text { displayed. }\end{array}$ & $\begin{array}{l}\text { Verify the following: } \\
\text { Tag Name - B106-LI-R001-01 } \\
\text { Formula - the waste level of E-L-STA-06- } \\
06-06-06\end{array}$ \\
\hline 16. & $\begin{array}{l}\text { Using the Sensor Details Update } \\
\text { function request a reading. }\end{array}$ & $\begin{array}{l}\text { Verify the current reading is retrieved and } \\
\text { displayed properly. }\end{array}$ \\
\hline 17. & $\begin{array}{l}\text { Display the workspace for Tank } \\
\text { B107. } \\
\text { Select the Details for the Enraf } \\
\text { displayed. }\end{array}$ & $\begin{array}{l}\text { Verify the following: } \\
\text { Tag Name - B107-LI-R008-01 } \\
\text { Formula - the waste level of E-L-STA-06- } \\
06-06-31\end{array}$ \\
\hline 18. & $\begin{array}{l}\text { Using the Sensor Details Update } \\
\text { function request a reading. }\end{array}$ & $\begin{array}{l}\text { Verify the current reading is retrieved and } \\
\text { displayed properly. }\end{array}$ \\
\hline 19. & $\begin{array}{l}\text { Display the workspace for Tank } \\
\text { B108. } \\
\text { Select the Details for the Enraf } \\
\text { displayed. }\end{array}$ & $\begin{array}{l}\text { Verify the following: } \\
\text { Tag Name - 108-LI-R008-01 } \\
\text { Formula - the waste level of E-L-STA-06- } \\
06-06-32\end{array}$ \\
\hline 20 . & $\begin{array}{l}\text { Using the Sensor Details Update } \\
\text { function request a reading. }\end{array}$ & $\begin{array}{l}\text { Verify the current reading is retrieved and } \\
\text { displayed properly. }\end{array}$ \\
\hline 21. & $\begin{array}{l}\text { Display the workspace for Tank } \\
\text { B109. } \\
\text { Select the Details for the Enraf } \\
\text { displayed. }\end{array}$ & $\begin{array}{l}\text { Verify the following: } \\
\text { Tag Name - B109-LI-R003-01 } \\
\text { Formula - the waste level of E-L-STA-06- } \\
06-06-33\end{array}$ \\
\hline 22. & $\begin{array}{l}\text { Using the Sensor Details Update } \\
\text { function request a reading. }\end{array}$ & $\begin{array}{l}\text { Verify the current reading is retrieved and } \\
\text { displayed properly. }\end{array}$ \\
\hline 23. & $\begin{array}{l}\text { Display the workspace for Tank } \\
\text { B1 } 10 . \\
\text { Select the Details for the Enraf } \\
\text { displayed. }\end{array}$ & $\begin{array}{l}\text { Verify the following: } \\
\text { Tag Name - B110-LI-R005-01 } \\
\text { Formula - the waste level of E-L-STA-06- } \\
06-06-34\end{array}$ \\
\hline 24. & $\begin{array}{l}\text { Using the Sensor Details Update } \\
\text { function request a reading. }\end{array}$ & $\begin{array}{l}\text { Verify the current reading is retrieved and } \\
\text { displayed properly. }\end{array}$ \\
\hline 25. & $\begin{array}{l}\text { Display the workspace for Tank } \\
\text { B111. } \\
\text { Select the Details for the Enraf }\end{array}$ & $\begin{array}{l}\text { Verify the following: } \\
\text { Tag Name - B111-LI-R001-01 } \\
\text { Formula - the waste level of E-L-STA-06- }\end{array}$ \\
\hline
\end{tabular}




\begin{tabular}{|c|c|c|}
\hline & displayed. & $06-06-35$ \\
\hline 26. & $\begin{array}{l}\text { Using the Sensor Details Update } \\
\text { function request a reading. }\end{array}$ & $\begin{array}{l}\text { Verify the current reading is retrieved and } \\
\text { displayed properly. }\end{array}$ \\
\hline 27. & $\begin{array}{l}\text { Display the workspace for Tank } \\
\text { B112. } \\
\text { Select the Details for the Enraf } \\
\text { displayed. }\end{array}$ & $\begin{array}{l}\text { Verify the following: } \\
\text { Tag Name - B112-LI-R004-01 } \\
\text { Formula - the waste level of E-L-STA-06- } \\
06-06-36\end{array}$ \\
\hline 28. & $\begin{array}{l}\text { Using the Sensor Details Update } \\
\text { function request a reading. }\end{array}$ & $\begin{array}{l}\text { Verify the current reading is retrieved and } \\
\text { displayed properly. }\end{array}$ \\
\hline 29. & $\begin{array}{l}\text { Display the workspace for Tank } \\
\text { B201. } \\
\text { Select the Details for the Enraf } \\
\text { displayed. }\end{array}$ & $\begin{array}{l}\text { Verify the following: } \\
\text { Tag Name - B201-LI-R008-01 } \\
\text { Formula - the waste level of E-L-STA-06- } \\
06-06-61\end{array}$ \\
\hline 30. & $\begin{array}{l}\text { Using the Sensor Details Update } \\
\text { function request a reading. }\end{array}$ & $\begin{array}{l}\text { Verify the current reading is retrieved and } \\
\text { displayed properly. }\end{array}$ \\
\hline 31. & $\begin{array}{l}\text { Display the workspace for Tank } \\
\text { B202. } \\
\text { Select the Details for the Enraf } \\
\text { displayed. }\end{array}$ & $\begin{array}{l}\text { Verify the following: } \\
\text { Tag Name - B202-LI-R008-01 } \\
\text { Formula - the waste level of E-L-STA-06- } \\
06-06-62\end{array}$ \\
\hline 32. & $\begin{array}{l}\text { Using the Sensor Details Update } \\
\text { function request a reading. }\end{array}$ & $\begin{array}{l}\text { Verify the current reading is retrieved and } \\
\text { displayed properly. }\end{array}$ \\
\hline 33. & $\begin{array}{l}\text { Display the workspace for Tank } \\
\text { B203. } \\
\text { Select the Details for the Enraf } \\
\text { displayed. }\end{array}$ & $\begin{array}{l}\text { Verify the following: } \\
\text { Tag Name - B203-LI-R008-01 } \\
\text { Formula - the waste level of E-L-STA-06- } \\
06-06-63\end{array}$ \\
\hline 34. & $\begin{array}{l}\text { Using the Sensor Details Update } \\
\text { function request a reading. }\end{array}$ & $\begin{array}{l}\text { Verify the current reading is retrieved and } \\
\text { displayed properly. }\end{array}$ \\
\hline 35. & $\begin{array}{l}\text { Display the workspace for Tank } \\
\text { B204. } \\
\text { Select the Details for the Enraf } \\
\text { displayed. }\end{array}$ & $\begin{array}{l}\text { Verify the following: } \\
\text { Tag Name - B204-LI-R008-01 } \\
\text { Formula - the waste level of E-L-STA-06- } \\
\text { 06-06-64 }\end{array}$ \\
\hline 36. & $\begin{array}{l}\text { Using the Sensor Details Update } \\
\text { function request a reading. }\end{array}$ & $\begin{array}{l}\text { Verify the current reading is retrieved and } \\
\text { displayed properly. }\end{array}$ \\
\hline
\end{tabular}

\subsubsection{SR 916 - Change Gauge Address for Enraf in Tank AZ101}

\begin{tabular}{|l|l|l|l|}
\hline Step & Perform & Verify & Initial \\
\hline 1. & $\begin{array}{l}\text { Display the workspace for Tank } \\
\text { AZ101. }\end{array}$ & $\begin{array}{l}\text { Verify the following: } \\
\text { Tag Name-AZ102-LI-R22A-01 }\end{array}$ & \\
\hline
\end{tabular}




\begin{tabular}{|l|l|l|l|}
\hline & $\begin{array}{l}\text { Select the Details for the Enraf } \\
\text { displayed. }\end{array}$ & $\begin{array}{l}\text { Formula - the waste level of E-L-STA-06- } \\
00-00-67\end{array}$ & \\
\hline 2. & $\begin{array}{l}\text { Using the Sensor Details Update } \\
\text { function request a reading. }\end{array}$ & $\begin{array}{l}\text { Verify the current reading is retrieved and } \\
\text { displayed properly. }\end{array}$ & \\
\hline
\end{tabular}

\subsection{TMACS SHUTDOWN}

\subsubsection{Telewindows ${ }^{\circledR}$ Session}

\begin{tabular}{|l|l|l|c|}
\hline \multicolumn{1}{|c|}{ Step } & \multicolumn{1}{|c|}{ Action } & \multicolumn{1}{|c|}{ Verify } & Initial \\
\hline 1. & $\begin{array}{l}\text { On the TMACS screen, type } \\
\text { Control-Y. }\end{array}$ & $\begin{array}{l}\text { Verify that the user mode selection } \\
\text { workspace appears on the screen. }\end{array}$ & \\
\hline 2. & $\begin{array}{l}\text { Edit the 'G2 } \\
\text { "shutdown" and click on the } \\
\text { END. }\end{array}$ & $\begin{array}{l}\text { Verify that a warning message } \\
\text { appears indicating that this function } \\
\text { is not available. } \\
\text { Verify the 'G2 }{ }^{\circledR} \text { user mode' has } \\
\text { reverted back to "t2-user". }\end{array}$ & \\
\hline
\end{tabular}

\subsubsection{Central Console}

\begin{tabular}{|c|c|c|c|}
\hline Step & Action & Verify & Initial \\
\hline 1. & On the TMACS screen, type Control-Y. & $\begin{array}{l}\text { Verify that the user mode } \\
\text { selection workspace } \\
\text { appears on the screen. }\end{array}$ & \\
\hline 2. & $\begin{array}{l}\text { Edit the 'G2 }{ }^{k} \text { user mode' to be } \\
\text { "shutdown" and click on the END. }\end{array}$ & $\begin{array}{l}\text { Verify that } \mathrm{G} 2^{(1)} \\
\text { terminates. }\end{array}$ & \\
\hline 3. & $\begin{array}{l}\text { As part of the shutdown process } \\
\text { TMACS creates the following files in } \\
\text { the directory } \\
\text { F:IBackedUp\TMACS } \backslash \text { DatalCurrent: } \\
\text { - Continuous_Shutdown_History_ } \\
\text { YYYY_MMDD.ascii. } \\
\text { Discrete_Shutdown_History_ } \\
\text { YYYY_MMDD.ascii. } \\
\text { Where: } \\
\text { YYYY - is the year that the file was } \\
\text { created. } \\
\text { MM - is the month that the file was } \\
\text { created. } \\
\text { DD - is the day that the file was created. }\end{array}$ & $\begin{array}{l}\text { Verify that the files were } \\
\text { created and the format } \\
\text { match the description } \\
\text { given in "TMACS As- } \\
\text { Built Design Document" } \\
\text { HNF-SD-WM-SDD-079, } \\
\text { Current Revision. }\end{array}$ & \\
\hline
\end{tabular}


HNF-3967, Rev. 5

\section{PARTICIPATION RECORD SHEET}

The following page is the form used to record the participants involved in the running of this Acceptance Test Procedure. This sheet should be completed and included in the Acceptance Test Report. 
HNF-3967, Rev. 5

\section{Acceptance Test Procedure \\ Participation Record}

TEST DIRECTOR

TEST PERFORMANCE GROUP

TEST WITNESS 
HNF-3967, Rev. 5

\section{EXCEPTION SHEETS}

The following page is an example of the form used to describe exceptions found during the running of this Acceptance Test Procedure. If exceptions are found, copies of this sheet should be completed and included in the Acceptance Test Report. 
HNF-3967, Rev. 5

\section{Acceptance Test Procedure \\ Exception Record}

\begin{tabular}{|c|c|c|}
\hline Exception No. & Step No. & Date \\
\hline \multicolumn{3}{|l|}{ Originator/Organization } \\
\hline \multicolumn{3}{|l|}{ Description: } \\
\hline \multicolumn{3}{|l|}{ Resolution: } \\
\hline \multicolumn{3}{|l|}{ Resolution Date: } \\
\hline Title/Organization & Signature & $\overline{\text { Date }}$ \\
\hline \multicolumn{3}{|l|}{ Test Director } \\
\hline \multicolumn{3}{|l|}{ Cognizant Engineer } \\
\hline \multicolumn{3}{|l|}{ QA } \\
\hline & & \\
\hline & & \\
\hline & & \\
\hline & & \\
\hline & & \\
\hline
\end{tabular}




\section{DISTRIBUTION SHEET}

To

Distribution

Project Title/Work Order

Tank Monitor and Control System (TMACS) Acceptance Test Procedure (ATP)

Name

D.A. Barnes

J.S. Bryce

S.C. Cantrell

T. Erickson

J.G. Field

W.J. Kennedy

P.G. Miller

CC Scaief, III

D.D. $s \cot t$

D. T. Heimberger

$\mathrm{R}$. R. Wandling

W. L Adams

Central Files

DOE Reading Room

From

Data Development \& Interpretation

(

(n)

Page 1 of 1

Date 5/18/2000

EDT No. N/A

ECN No. 654988 